\title{
Geology of Unalaska
}

\section{Island and Adjacent}

\section{Insular Shelf, Aleutian}

\section{Islands, Alaska}

By HARALD DREWES, G. D. FRASER, G. L. SNYDER, and H. F. BARNETT, JR.

INVESTIGATIONS OF ALASKAN VOLCANOES

GE OLOGICAL SURVEY BULLET I N $1028-\mathrm{S}$

Prepared in cooperation with the

Office, Chief of Engineers, U.S. Army

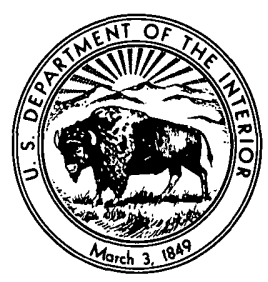


UNITED STATES DEPARTMENT OF THE INTERIOR

STEWART L. UDALL, Secretary

\section{GEOLOGICAL SURVEY}

y

Thomas B. Nolan, Director 


\section{PREFACE}

In October 1945, the War Department requested the U.S. Geological Survey to undertake a program of volcano investigations in the Aleutian Islands-Alaska Peninsula area. The resulting program was under the general direction of G. D. Robinson during 1946-48, and of H. A. Powers during 1949-54. Some of the results have been published in two administrative reports which, now revised, are largely incorporated in bulletins describing specific islands or groups of islands. Two bulletins (Coats $1950 ; 1951$ ) and parts of Bulletin 1028 are published; other parts of Bulletin 1028 are in various stages of completion.

The Army, Navy, and Air Force jointly furnished financial and logistic assistance, and the Geological Survey is indebted to these departments for their support. 



\section{CONTENTS}

Preface

Abstract._... 583

Introduction

Geography

Igneous and sedimentary rocks.

Unalaska formation

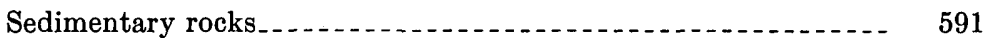

Flows, sills, pillows, and bulbous intrusive bodies.

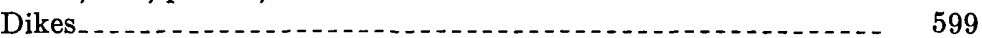

Petrography of the Unalaska formation

Specific data for analyzed rocks. . .

Alteration . 603

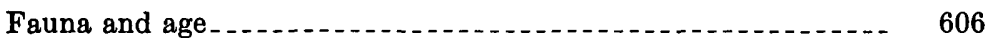

Environment and origin

Granodiorite batholith . . 610

Field relations............ 610

Petrography of the batholith

Shaler pluton

Beaver pluton............. 619

Captains pluton..... 620

Aplites and pegmatites

Small holocrystalline intrusive bodies . . . . .

Recrystallized wallrocks........ 622

Comparative mineralogy

Specific data for analyzed rocks . .

Alteration

Plutonic rocks: summary and interpretation:

Makushin volcanics._._. 634

Unconformity beneath the Makushin volcanics_. _._.

Petrography of the Makushin volcanics _.

Specific data for analyzed rocks. . .

Age of the Makushin volcanics. 641

Eider Point basalt .

Makushin Volcano; fumaroles and hot springs...._.

Pakushin Cone. ... 642

Point Kadin vents........ 643

Bishop Point volcanic mudflow

Sugarloaf Cone and lava flows....... 644

Cone and lava flows of Tabletop Mountain

Wide Bay cone... 645

Other possibly young flows

Petrography of the Eider Point basalt.....

Specific data for analyzed rocks. 645

Surficial deposits and geomorphology

Glacial landforms and deposits .......... 646

Stream erosion and alluvium. 648

Colluvium and eolian deposits... 649

Soil-ash profiles.

Eolian features............ 652

Marine erosion and deposits 
Structural geology

Faults

Volcanic structures

Linear features..............

Economic geology

Sulfur...

Gold

Zinc . . .

Other mineralization

Potentialities of economic deposits...

Submarine geology

Physiography _... 660

Insular shelf . . .

Lower insular shelf . .

South insular slope.

North insular slope.

Bering Basin and Continental Slope

Wave and current activity

Glacial features.

Submarine structure.............. 665

Geologic history

Literature cited... 669

Index

\section{ILLUSTRATIONS}

[Plates are in pocket]

Plate 75. Geologic map of Unalaska Island, Alaska, and adjacent submarine area.

76. Percent frequency distributions of mineral amounts and plagioclase composition parameters in holocrystalline rocks of Unalaska Island.

77. Analysis of linear features in the rocks of Unalaska Island.

78. Map and fence diagram showing geographic distribution of holocrystalline igneous rock types in the Skan Bay-Naginak Cove area of the Shaler pluton.

Figure 81. Map of southwestern Alaska

82. General view of a part of Unalaska Island

83. Homogeneous tuff breccia from vertical sea cliff on north shore of Boulder Bay

84. Large pillows, layered argillites, and sills in a sea cliff about 900 feet high on the east side of Reef Point, southwestern Unalaska.

85. Partially brecciated pillows from near the top of small intrusive body exposed in the bench on the south side of the north arm of Kismaliuk Bay.

86. Disruption of sills, Tower Point, southwestern Unalaska...-.

87. Horizontal section of a layered dome on a tidal bench along the west side of Alimuda Bay, western Unalaska Island 
FrgURE 88. Silica variation diagram of igneous rocks of Unalaska Island.. 604

89. Alteration and mineralization on Unalaska Island _. . . . . 609

90. View south toward 3600 Mountain roof pendant, showing Shaler pluton and Unalaska formation . -

91. Joint pattern in homogeneous central granodiorite of Shaler pluton, looking south from south shoulder of 3600 Mountain.-

92. Joint pattern in inhomogeneous border rocks of Shaler pluton on Kof Point. .

93. Percent-frequency distributions of the average percent anorthite in plagioclase crystals of typical holocrystalline rocks of Unalaska Island

611

613

614

94. Typical phaneritic rocks from the Shaler pluton of Unalaska Island.

95. "Plum-pudding" contact rock from large polished beach boulder at head of north arm of Skan Bay

96. Recrystallized inclusions of layered argillite in gabbro from small stock on north side of Humpback Bay

97. Combined distribution of total mafic mineral content and anorthite content of average plagioclase for holocrystalline rocks of Unalaska Island.

98. Concentric mineral zones within Shaler pluton.......... 632

99. Makushin Volcano, looking southeast from an airplane over Point Kadin.

100. Isometric diagram of Makushin Volcano area, Unalaska Island.

101. Map of northern Unalaska Island

102. Soil-ash profiles........ 651

103. Block diagram showing relation between shelf ice and a pseudo

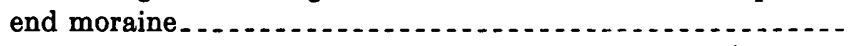

\section{TABLES}

TABLE 1. Chemical composition, normative values, CIPW nomenclature, and Rittmann nomenclature for Unalaska Island rocks ... In pocket

2. Incidence of holocrystalline rock types on Unalaska Island . - 617

3. Unalaska Island faults and their displacement. . _._. 


\title{
INVESTIGATIONS OF ALASKAN VOLCANOES
}

\section{GEOLOGY OF UNALASKA ISLAND AND ADJACENT INSULAR SHELF, ALEUTIAN ISLANDS, ALASKA}

\author{
By Harald Drewes, G. D. Fraser, G. L. Snyder, \\ and H. F. BARNETT, JR.
}

\section{ABSTRACT}

Unalaska Island is the second largest island west of the Alaska Peninsula and includes about 1,200 square miles. Most of the island is ruggedly mountainous and the coastline is deeply indented by fiords, but the southwestern end is hilly and is less deeply indented by bays. Makushin Volcano is still active and forms a broad, glacier-capped, truncated cone rising 6,680 feet above the sea on the northern bulge of the island.

The oldest rocks on the island, the Unalaska formation, consist of altered andesitic intrusive and extrusive rocks, and sedimentary rocks derived from similar igneous rocks. Conglomerates and coarse breccias are the dominant sedimentary rocks in the northern and eastern part of the island ; finer epiclastic and pyroclastic rocks, particularly argillite, are dominant in the south. Fragments of a desmostylid, distant relative of the modern sea cow, date some of the formation as early Miocene. The coarse facies is probably a nearshore marine deposit; the finer facies suggest deposition in deeper basins. Conspicuous, bulbous igneous masses whose diameters range from a few feet to several hundred feet were intruded into and possibly extruded upon muds and are associated with pillow lavas.

The batholiths are granodiorite; the heterogeneous border phases are as mafic as gabbro against hornfelsed argillites as mafic as, and equivalent in composition to, melagabbro. Belts of hydrothermal wallrock alteration surround the batholiths, which were themselves slightly altered by deuteric solutions, and several areas of wallrocks were dynamically metamorphosed when the adjacent batholiths were intruded. Assimilation, stoping, and forceful intrusion were all active mechanisms of emplacement. The core of one batholith is relatively rich in quartz, potassic feldspar, allanite, and amphibole, indicating either hydrothermal introduction of these materials or only slight contamination of the core by assimilated basic material.

Basalt and andesite flows and pyroclastic rocks of the Makushin volcanics unconformably cap the Unalaska formation and plutonic rocks and form most of Makushin Volcano. The surface on which they rest has a relief of about 3,000 feet, comparable with the relief of the present topography; and the major valleys on the unconformity lie close to the present drainage systems. Most of the rocks are porphyritic and trachytic, containing as essential minerals andesine or laboradorite, augite, hypersthene, and olivine. The bulk of the Makushin volcanics is probably of late Pleistocene age. Practically all rocks exposed were deposited subaerially. 
Rocks of scattered cinder cones, composite cones, and lava flows with young constructional forms make up the Eider Point basalt, most of which is late Wisconsin to Recent in age, and which includes the recent products of stillactive Makushin Volcano. These volcanic rocks rest unconformably on glaciated rocks of the Makushin volcanics; some are in turn slightly glaciated. Most of the Eider Point basalt is porphyritic and trachytic and many specimens contain up to 2 percent partly resorbed xenocrysts. Bytownite or labradorite, augitic pyroxene, olivine, and hypersthene are the essential minerals. The explosion craters at Point Kadin are associated with a very small amount of andesite vitrophyre. The summits of Makushin Volcano and Pakushin Cone contain breached craters.

Thirty-four new chemical analyses, and spectrographic analyses of trace elements of many of these rocks, are tabulated. The rocks belong to the calcalkaline suite common to the Aleutian island arc.

Much of the island is discontinuously veneered by a thin mantle of till, volcanic ash, humus, and soil. Moraines are restricted to the vicinity of the present glaciers. Beaches raised in Recent time are local and poorly preserved.

The Unalaska formation is faulted, tilted, and warped; the structure of the island is poorly understood because few stratigraphic horizons are mapped. A statistical analysis of linear topographic features from aerial photographs shows a dominantly northwest trend in the more altered rocks near and in the batholiths, and a strong rectilinear pattern of north- and east-trending sets of linear features in the less altered rocks away from the batholiths.

Sulfur, gold, zinc, and copper occur in small deposits on the island, but under the present market conditions the economic potentials of these prospects are unfavorable.

Inferences regarding glacial and structural geology are extended by interpretation of a submarine contour map covering 12,000 square miles of the surrounding area. The island is the subaerial part of the wave-beveled platform of the Aleutian Ridge, here about 40 miles wide, that extends to a depth of about 500 feet, with incised slopes to deep water beyond. The amount and rate of marine erosion suggest that the insular shelf is no older than middle Pleistocene. Most of the Makushin volcanics and all of the glaciation of the island postdate the marine beveling of the platform.

\section{INTRODUCTION}

The geological reconnaissance of Unalaska Island, near the eastern end of the Aleutian Islands (fig. 81), was made during the summers of 1953 and 1954 . The geology was mapped mostly on six topographic maps, scale 1:62,500, prepared by the U.S. Army Engineers in 1940 and 1941. Most of these maps have a contour interval of 100 feet and are generally accurate, but the southwestern end of the island is shown only by form lines, which locally are highly inaccurate. In the few unsurveyed portions of the maps, which were cloud covered on the compilation photographs, and in parts of the area of form-line maps, the geology was mapped on more recent aerial photographs. Submarine topography was compiled from smooth sheets (sounding charts) available from the U.S. Coast and Geodetic Survey.

Logistic problems involved transportation, inclement weather, great relief, and heavy upland snow cover. The motorship Eider, then of 


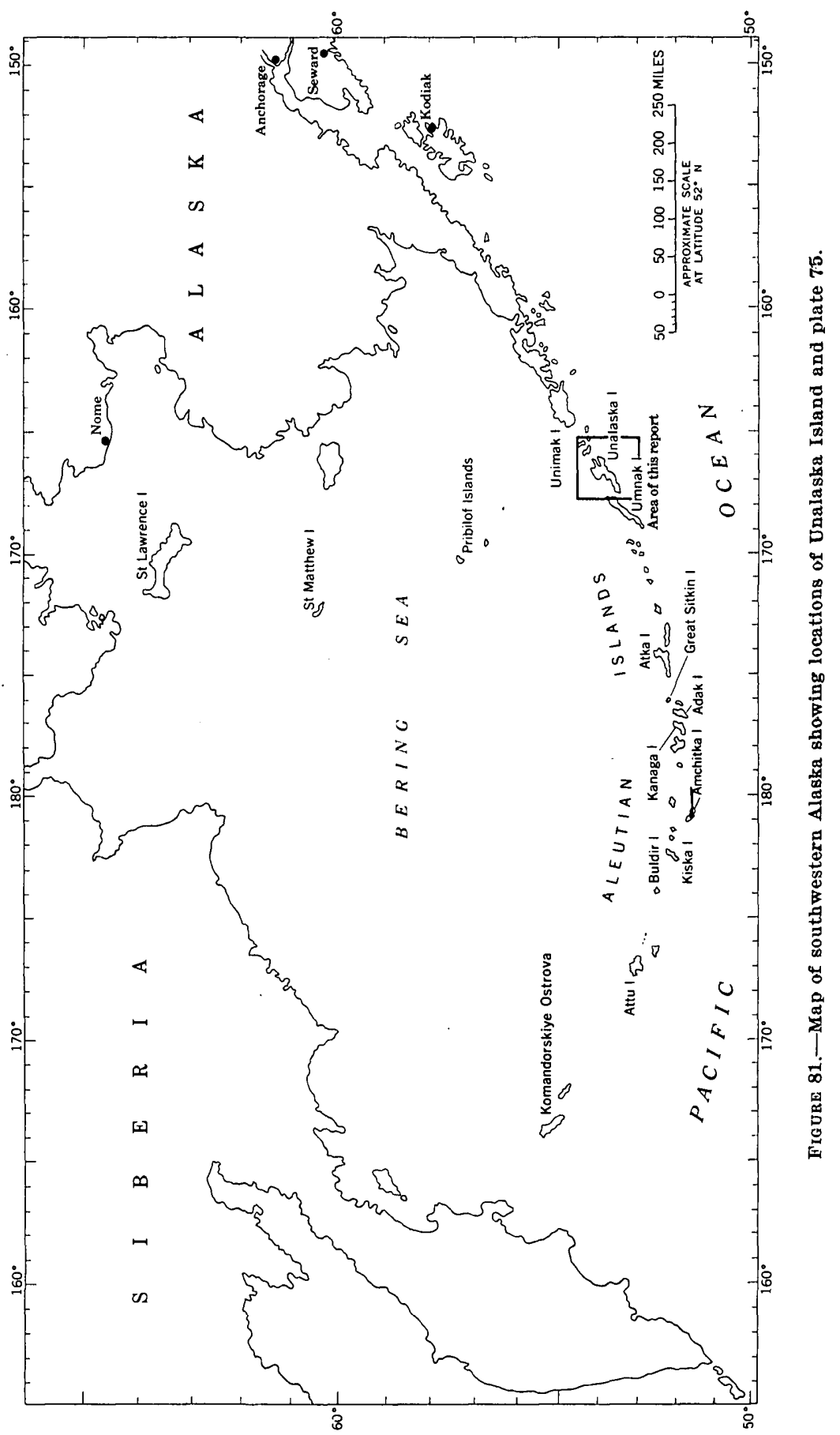


the Geological Survey, provided transportation to and around the island and served as supply base for the shore parties. In places short traverses were made in a powered skiff, and near the village of Unalaska trucks occasionally were used, but most of the island was mapped on foot by four two-man parties operating independently. The high terrain around Makushin volcano was reached from temporary advanced camps.

The geology was mapped in 1953 by G. D. Fraser, G. L. Snyder, H. F. Barnett, Jr., and E. H. Meitzner, assisted by V. E. Ames, R. P. Platt, H. B. Smith, and L. D. Taylor. The following year the geology was mapped by Fraser, Snyder, Barnett, and Harald Drewes, assisted by Platt, Smith, W. B. Bryan, and C. E. Chapin. In both years the parties were led by Fraser, Carl Velvelstad, captain, Charles Best, engineer, and the crew of the Eider provided constant and capable service.

The cooperation of the commanding officers and other military personnel at Kodiak Naval Base, and of the men of the Marine detachment at Dutch Harbor, is sincerely acknowledged. The friendly help of many of the inhabitants of Unalaska village, and particularly that of Walter Dyakanoff, mayor and manager of the Northern Commercial Co. store, is greatly appreciated.

The first Europeans to visit Unalaska Island were Russians under the command of Korovin on August 15, 1763, according to Coxe (1787, p. 103), though other accounts by him and by Grewingk $(1850$, p. 314$)$ suggest that other fur hunters may have preceded Korovin shortly. In following years many others arrived, and Captains Bay soon became a Russian outpost. In 1778 James Cook stopped at Unalaska (Collins and others, 1945, p. 12). Accounts of the early history of the Aleutians and of the natives and their customs are presented by Jochelson (1933), Hrdlička (1945), Collins, Clark, and Walker (1945), and by Laughlin and Marsh (1951).

The geologic map and description by Grewingk (1850) probably is the earliest geologic work done on Unalaska Island. In 1907, T. A. Jagger, A. S. Eakle, and others of the Technology Expedition (Massachusetts Institute of Technology) spent several weeks on Unalaska Island to study the geology and botany. Only a diary was published by them (Jagger, 1908, p. 1037), but most of the notes, manuscripts, and geologic collections were available for the present report and several thin sections were cut from Jaggar's specimens. During the early part of this century, several short papers were written on the gold, zinc, and sulfur prospects; these are discussed in the section on mineral deposits. S. R. Capps (1934, p. 147-149) briefly reconnoitered the Unalaska Bay and Chernofski Harbor areas. In 1948 F. M. Byers, H. H. Waldron, and others made a preliminary geologic 
study of parts of the island for the U.S. Geological Survey, and their maps, notes, and collections were available in the preparation of this report. The geologic map of Alaska (Dutro and Payne, 1957) shows the early ideas of several of the authors of this report.

\section{GEOGRAPHY}

Unalaska Island, second largest in the arcuate chain of Aleutian Islands extending from the Alaska Peninsula to Kamchatka Peninsula, is located between latitudes $53^{\circ} 15^{\prime}$ and $54^{\circ} \mathrm{N}$., and between longitudes $166^{\circ}$ and $168^{\circ} \mathrm{W} ., 130$ miles southwest of the Alaska Peninsula. East of Unalaska Island are the smaller islands of Unalga, Akutan, Akun, and the Krenitzin Group, and the largest Aleutian island of Unimak. Umnak Island, smaller than Unalaska Island, lies to the west across a strait 4 miles wide. Sedanka, Amaknak, and Hog Islands are separated from Unalaska Island by straits less than onefourth mile wide and, unless specifically omitted, these three adjacent islands and numerous islets will hereafter be included with Unalaska Island in all general description. Amaknak Island is the site of Dutch Harbor Naval Base.

Unalaska Island is elongate at about N. $60^{\circ} \mathrm{E}$., the trend of this segment of the Aleutian arc. It is 85 miles long and 39 miles wide and has an area of about 1,200 square miles. The active Makushin Volcano (fig. 99) is north of the main elongation of the island and in line with volcanos of the adjacent islands. Numerous photographs of the volcano and other features illustrate an article by Freiday (1945 p. 444-455).

Many fiords embay the coast (fig. 82; pl. 75) : Beaver Inlet, which is more than 20 miles long, splits the eastern end of the island; Unalaska and Makushin Bays are each more than 10 miles long. Smaller bays and fiords are abundant everywhere except around the north shore of the northern bulge and on the southwest end of the island. Much of the coast is fringed with narrow, steep boulder beaches and rock benches, bare at low tide and interrupted in many places by cliffs. Beaches and tidal benches (fig. 87) are narrowest around protected bays; broad sand and gravel beaches commonly lie at the heads of shallow bays exposed to strong wave action. Further details on beach and bar physiography are discussed with the deposits that form them.

Makushin Volcano, the most conspicuous landform on the island, is 6,680 feet high. Its broad, domical summit is capped by a glacier with tongues that descend the larger flanking valleys to elevations as low as 1,000 feet. Several symmetrical conical hills and craters are on the flanks of Makushin Volcano. 


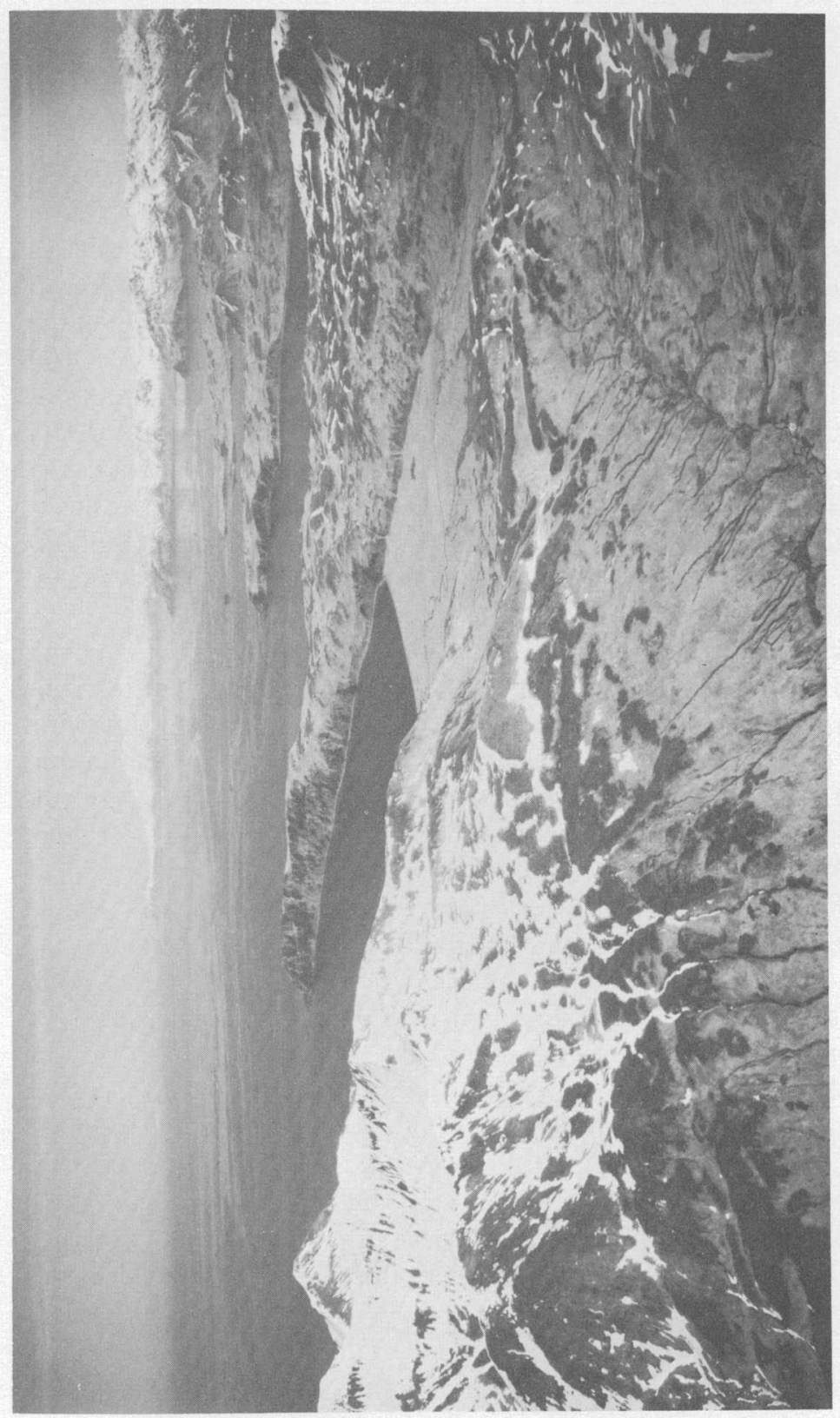

矛范

$\&$ 묘

过范

잉

๑ै

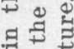

잉

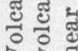

=

톱워

때요

ङ

...

농

현

\& 8

क्ष

क ह ․ำ

寻午

प2 0

영

品 룰

逮

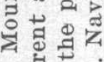

வ

항

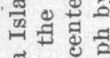

苋苋范

모요

4 पू

+ త్

范



०

엉 명

풀 영

워의

कु से

๙

刍 
South and east of Makushin Volcano the terrain is rugged. Sharp ridges and peaks commonly reach 1,800 feet in elevation on the easternmost part of the island and are progressively higher toward the center of the island, where they exceed 3,500 feet. Small glaciers remain in some of the highest valleys. West of Kashega the peaks are subdued, and around Chernofski Harbor only a few rolling hills are more than 1,200 feet high. Peaks in the rugged part of the island appear on distant view to have accordant summits (figs. 82, 99) but they range 1,500 feet in elevation, so that the accordance is more an illusion than a reality. There is a crude terrace at about 600 feet elevation west of Kashega.

The character of valleys varies with their size, the ruggedness of the surrounding land, and the presence or absence of glaciers in the drainage basins. In the more rugged areas, the larger valleys are narrow, with discontinuous broad and flat segments. Outwash-filled valleys are exceptionally broad and flat. Lakes are most numerous in flat terrain; lakes on the western end of the island and near English Bay on the eastern end are small and shallow, and lakes in the upland or valley basins of the rugged central area are deep. Lakes and closed lagoons are conspicuous in the lower reaches of many broad valleys; some are several miles long.

Wind, rain, fog, and overcast make the weather of the Aleutian Islands unpleasant and navigation hazardous. The mean annual precipitation is 58 inches at Dutch Harbor and 52 inches at Chernofski Harbor. Most of the precipitation falls as snow during the winter and as drizzle at other times, and on an average of 221 days per year exceeds 0.01 inch. Fog is most common during the summer, and gales and williwaws (local, very strong, gusty winds) are most frequent during the fall and early winter. Mean summer temperatures are about $52^{\circ} \mathrm{F}$; mean winter temperatures are about $30^{\circ} \mathrm{F}$. At low elevations the snow accumulation is small because of the relatively warm maritime climate, but above 2,000 feet the accumulation is large and much snow persists into late summer. Further details of weather conditions are available from the "Climatic Atlas for Alaska" (U.S. Army Air Forces, 1943), which contains a record covering 16 to 26 years at Dutch Harbor and 4 to 8 years at Chernofski Harbor.

Trees are virtually lacking on the island. Several groves and a few isolated trees of Sitka spruce were.planted by the Russians in 1840 (Jaggar, 1908, p. 9) around Unalaska Bay, and of these only the grove on Hog Island appears to be spreading. Willow thickets grow at low elevations in the more protected valleys; blueberry shrubs and salmonberry and crowberry plants are common. In the flat lowland valleys tall grass and herbaceous plants are abundant, and the 
uplands are largely covered with heath and tundra vegetation. During the summer the meadows abound with a large variety of flowers.

The fauna of the island is small, consisting of indigenous foxes, lemming, and mice, and introduced ground squirrels, sheep, and rabbits (on Hog. Island only). The sea supports abundant bird life: ducks, geese, cormorants, puffins, murres, gulls, and a host of other birds. Seals and sea lions are found along the shore, and fish and invertebrates are plentiful.

The village of Unalaska, the nearby naval base at Dutch Harbor, and a sheep ranch at Chernofski Harbor were the only permanently inhabited places on the island in 1953 and 1954. The abandoned villages of Biorka, Makushin, and Kashega, seasonal fishing camps, and the extensive abandoned military bases of Fort Mears and part of Fort Glenn are located on many bays. A few wharfs and many miles of roads were built at Chernofski Harbor and Unalaska Bay. The airport at Dutch Harbor is still in use.

\section{IGNEOUS AND SEDIMENTARY ROCKS}

\section{UNALASKA FORMATION}

The oldest rocks on Unalaska Island, here named the Unalaska formation, are exposed over two-thirds of the island. It is a thick sequence of coarse and fine sedimentary and pyroclastic rocks intercalated with dacitic, andesitic, and basaltic flows and sills, cut by numerous dikes and small plutons and unconformably covered by basalt and andesite of the Makushin volcanics. The rocks of the Unalaska formation are typically exposed along the upper reaches of the Nateekin River and in the sea cliffs at Hive Bay.

High ridges of the Unalaska formation are irregularly jagged in appearance and are without the massive bosses of the plutonic rocks or the well-developed layered habit of the younger volcanic rocks. Steep slopes at lower elevations are smoother and are covered with relatively fine rubble and surficial deposits through which scattered outcrops project. Some of these steep slopes show crude, gently dipping, massive outcrop bands encircling hills. Grassier slopes-usually at even lower elevations-have fewer exposed rocks, which are irregularly distributed except where they occur as parts of linear outcrops commonly associated with terrace or bench topography. The rocks of the Unalaska formation are somber brownish gray and greenish gray, with scattered yellowish-gray to reddish-brown patches as large as a few thousand feet across. The somber appearance of the rocks probably is intensified by constant wetness. Sea cliffs along the south shore are banded in contrasting very light and dark grays. On southwestern Unalaska rounded igneous masses break the layered continuity and locally form the entire sea cliff. 
Extensive surficial cover, the massive nature of the important igneous and pyroclastic members, and the lack of key beds prohibit subdivision of the unit; these factors also make difficult a close estimate of the total thickness. Topographic relief indicates a minimum thickness of 3,000 feet; a maximum thickness of 55,000 feet is calculated from the regional dip of the rocks of $15^{\circ}$ to the north-northwest on the eastern part of the island, but duplication by faults and flexures is likely. The formation is probably a few tens of thousands of feet thick.

\section{SEDIMENTARY ROCKS}

The clastic components of the Unalaska formation are mostly argillites south of Beaver Inlet, graywacke and conglomerate in the northern bulge area and south of Makushin Bay, and coarse pyroclastic deposits in northeastern Unalaska Island, separated by wide transition zones. Graywackes, conglomerates, and pyroclastic rocks also form minor components of the rocks in other areas. Along the south coast of Unalaska Island the dominant sedimentary rock is layered argillite, well exposed in sea cliffs and headlands, but mostly covered in the interior of the island. Argillite is found as far north as 1 mile north of Portage Bay, where it is intercalated with coarse graywacke. Coarse graywacke is conspicuous south of Portage Bay for at least 1 mile and occurs as a minor constituent in the argillite sequence on the south coast of the island. There is thus a lateral gradation by intertonguing between argillite and graywacke across the neck between northern and southern Unalaska Island, but the northerly dips of that region indicate that exposed coarse beds may. be partly younger than the fine beds.

The argillite layers are generally darker in the grossly banded sea cliffs than the albitized sills with which they occur; argillite and sills make up about equal portions of the stratigraphic section. The rock colors are light or dark gray, with low-chroma greenish and brownish hues most common. 'Thinner argillite units appear on figures 84 and 86 , and some argillite is characterized by varvelike lamination. Some rocks split along laminae into thin, brittle chips, but more commonly they break across bedding with a conchoidal fracture.

Southwest of Cape Prominence much of the argillite was intruded by penecontemporaneous andesitic sills, domical masses, detached igneous pods, and pillow lavas. The unusual "intrusive flows," not recognized in the coarser clastic rocks farther north, are discussed below. Many andesitic dikes, sills, and irregular intrusive masses of more conventional habit occur within the Unalaska formation, but true flows are rare or absent in the argillite section. Chalcedonic and cherty masses, as well as crystalline quartz masses, are common in some areas of pillow lavas.

$5805370-61--3$ 
Typical section of part of the Unalaska formation, from the east shore of the bay west of Hive Bay; thicknesses are estimated.

Thickness (feet)

Top of section.

Upper porphyry :

Andesite sill, light-gray; weathers grayish yellow; feldspar porphyry, altered; cut by many dark-gray andesite dikes; lower contact irregular

Upper argillite :

Argillite, light- to dark-gray, laminated; weathers grayish brown; gross black-and-white layered appearance; contains minor crystal tuff, graywacke, and pépérite(?) layers; cleavage locally developed, some beds crenulated; cut by andesite dikes

Argillite, greenish-gray, laminated; contains altered, undeformed layers, very siliceous layers, dark chert layers, and sheeted pépérite(?) layers 6 in. to $3 \mathrm{ft}$ thick

Argillite, brown Middle porphyry :

Andesite sill, grayish-red; altered feldspar porphyry; highly irregular top of sill penetrates overlying argillite. Base of sill exposed at head of bay

Lower argillite :

Argillite, brown and light-gray, laminated.

Argillite, contains zone of crenulated beds

Argillite and tuff, brown, laminated.

Breccia, green, laminated tuffaceous

Argillite, laminated, brown

Siltstone, pale-yellowish brown; beds 1 to 2 in. thick__._-_._._._. 12

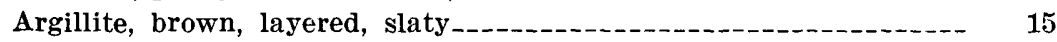

Tuff or graywacke, brown- to grayish-green

Argillite, gray to brown, laminated; contains coarse nonlaminated layers 2 or 3 in. thick.

Tuff or graywacke, dark-brown to green, well indurated._._.....

Argillite, brown, laminated.

Siltstone, pale-yellowish-brown; beds 2 in. to $1 \mathrm{ft}$ thick

Argillite, brown, laminated, slaty 15

Tuff or graywacke, brown to grayish-green

Argillite, grayish-brown, laminated; contains nonlaminated layers 2 to 3 in. thick

Tuff or graywacke, dark-brown to green, well indurated..........

Argillite, brown to black, laminated.....

Siltstone, yellow

Siltstone, gray

Argillite, gray, weathers dark brown, laminated, slaty_._._._._._. 12

\section{Lower porphyry :}

Andesite sill, grayish-red; altered feldspar porphyry. Best exposed at the mouth of the bay-_.. 200

Approximate total_-_. 
Coarse sedimentary and pyroclastic rocks of the Unalaska formation include much graywacke and tuffaceous sandstone, and mudstone. Conglomerate, agglomerate, and coarse breccias are common on northcentral Unalaska Island, and tuff breccia on the northeastern end. Bedding in the coarser sediments is characteristically crude and lithologic units are massive. One prominent zone of thick-bedded coarse conglomerate along the upper part of the Nateekin River is shown schematically on figure 100. A horizontal unit of coarse bluish-green tuff more than 300 feet thick caps the highest hills between Lion Bight and Alimuda Bay south and southwest of Kashega.

Most of the fragments in the coarser clastics consist of assorted angular to subrounded andesite or basalt common in the Unalaska formation (fig. 83). Some graywacke and tuffaceous sandstone contains boulders in an unsorted matrix. A few tuffaceous rocks contain pumice shards and obsidian fragments with relict perlitic structure, and other tuffs contain scattered angular fragments of pyroxene and plagioclase. In the vicinity of Unalaska village the sandstone is relatively clean, moderately well sorted, and contains the few fossils found on the island.

\section{FLows, SILls, PILlows, AND BULBous INTRUSIVE BODIES}

In parts of northern and northeastern Unalaska Island, lava flows occur with coarse pyroclastic, sedimentary, and intrusive rocks. Lofty Mountain and adjacent hills between Unalaska village and English Bay, for example, are unconformably capped by about 800 feet of andesite or basalt flows which weather to smoother topographic form than do the clastic rocks below them. The uncomformity beneath these flows is the most conspicuous of several within the Unalaska formation-so much more conspicuous that an alternate interpretation of placing the flows with younger volcanic rocks is possible. The flows are generally porphyritic, nonvesicular, irregularly fractured, and in places have a reddish oxidation color.

In southern Unalaska Island most of the igneous rocks within the Unalaska formation are sills or peculiar modifications of sills, whose structures are suggestive of both intrusive and extrusive rocks. Adjacent to some of these sills are concordant layers of rock a few feet to a few tens of feet thick that look like decomposed concrete and contain coarse, oriented greenish-gray chips of laminated argillite in a light-gray matrix of highly altered and brecciated igneous material. Bleached plagioclase crystals are visible in many specimens.

Unequivocal sills are especially conspicuous in the argillites along the south coast from Sedanka Island to Usof Bay, where they range from a few feet to more than 300 feet in thickness and make up about half of the section. Apophyses intrude overlying argillites, and in one area a large necklike mass projects from a sill through a thick 


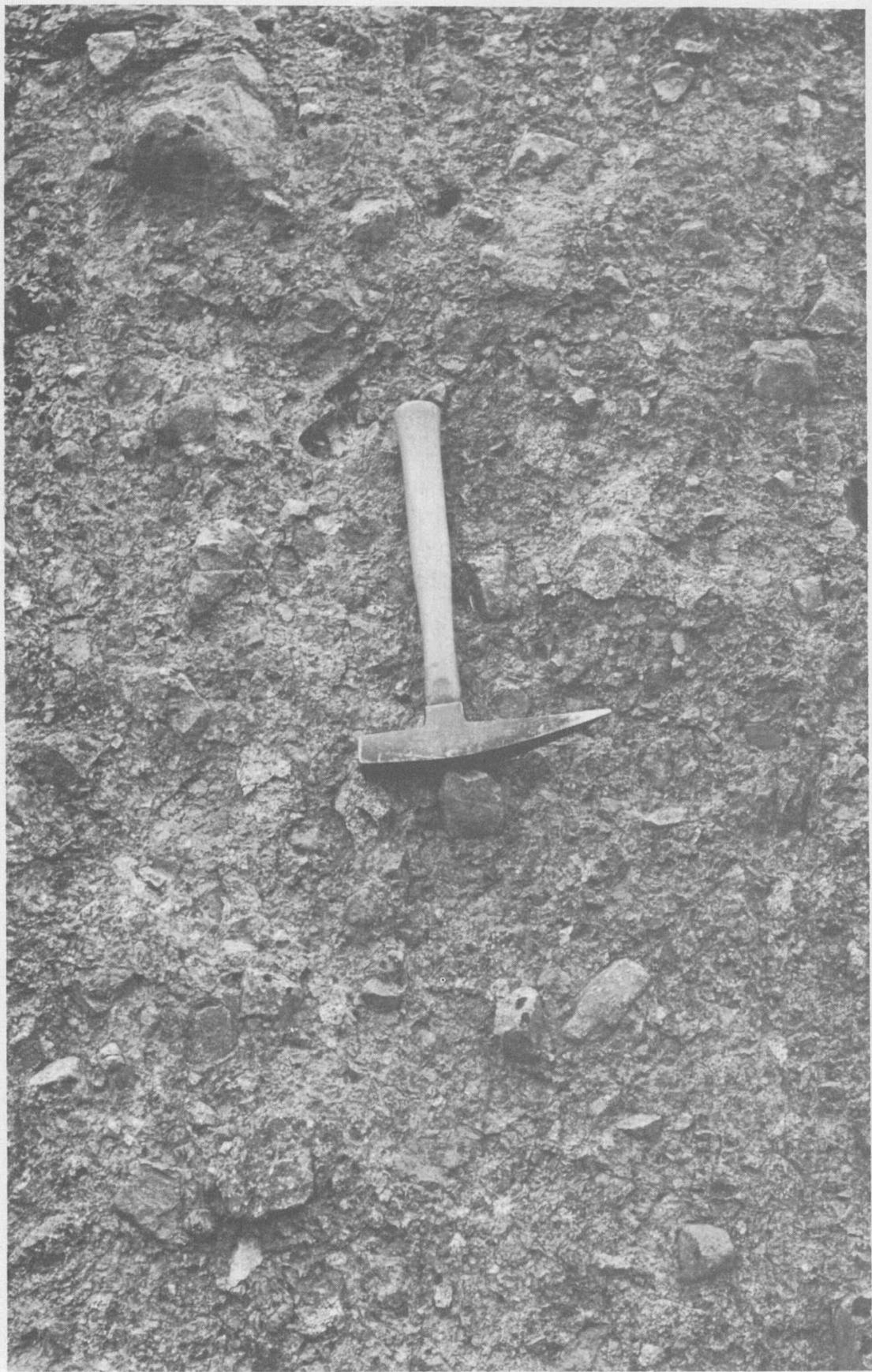

FIGURE 83.-Homogeneous tuff breccia from vertical sea cliff on north shore of Boulder Bay. Rocks of this type, characteristic of much of the Unalaska formation, have been formed variously as accumulations of nearshore submarine pyroclastic ejecta, mudflow deposits, autoclastic flow breccia, and intrusive breccia. 
overlying sequence of argillite. A few of the sills are partly discordant and cut the argillite layers at a slight angle. Most sills are massive and some have columnar structure and horizontal layering. Colors range from very light gray to grayish purple.

In addition to the massive sills, and occurring with them in a section several thousand feet thick stretching along 80 miles of coastline on the southwestern portion of southern Unalaska, is an irregularly stratiform mixture of argillite and igneous rock (figs. 84-87) that includes modified sills or "intrusive flows" with many unusual structural features. These features range from small glassy nodules to pillows and small laccoliths. In general, altered mud forms a matrix for the pillows; this mixture of mud and pillows surrounds, in turn, larger pods, domes, or laccoliths several hundred feet high. The smallest structures, examined in detail 1 mile northeast of Cape Aiak, for example, are glassy nodules or crudely rounded pods, about fist size, set in a matrix of much altered greenish sedimentary material. Here the nodules constitute less than one-fourth of the whole unit, which is massive and at least several tens of feet thick. Along the contact of this unit with a bulbous aphanitic intrusive mass that truncates it is a zone of breccia mixed with tongues and pods of the aphanite.

Irregular large pillows up to 40 feet long, but commonly 5 to 10 feet long, are abundant (fig. 84). Some are elongate and are variously oriented within the same layer. Tabular chunks of banded argillite, and tabular or irregular masses of green cherty material (believed to be altered siliceous mud) occur between the pillows throughout units as thick as several hundred feet. Light-gray chalcedonic and cherty deposits with typical crustification banding line cavities and fractures. Most of the pillows are unzoned but some have firm reddish rims and friable greenish-gray cores, and others have glassy borders and altered cores. Glass or mudstone occurs inside some deformed pillows. Sheets of pillows grade into bulbous sills by way of larger, irregular pillows. Pillows also appear as buds forming at the apex of a small, deltoid-shaped laccolith. In rare cases septa of overlying argillite project into pillow layers, and at Raven Bay delicate branching andesite tongues penetrate into the overlying argillite.

Pillows only a few feet in maximum diameter, featured by chilled outer margins, vesicles, radial and concentric fractures, slightly dimpled or depressed undersides where in contact with underlying pillows, and including a sedimentary filling between pillows, occur in a few places. As shown in figure 85, they are much smaller than the large irregular pillows discussed above and obviously are less deformed. 


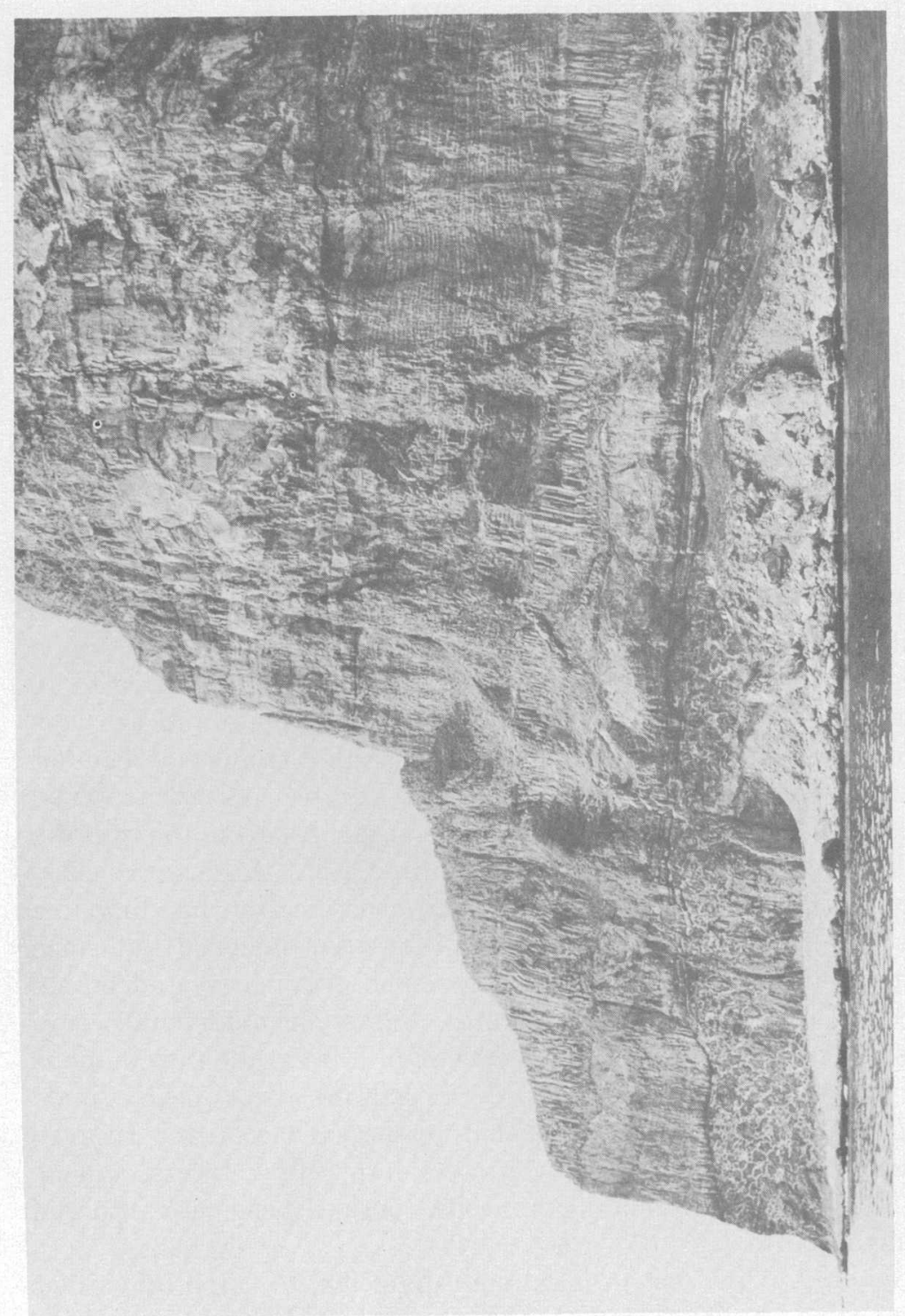

苛岁 क

范

\%ัญ

요

때

큰

ช

oै

ह

규

동 웡 क्ष

궁

ב.

\&

표

\&ँ

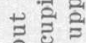

ڤ요

용

o

ㅉㅀ

\%

$\Xi 5$

을

ซี สี

듈

๘

की

范薄

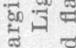

ซ

혼

产票曹

is

플

ㄹ.

एव

촐

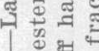

मㄹ

国范导 


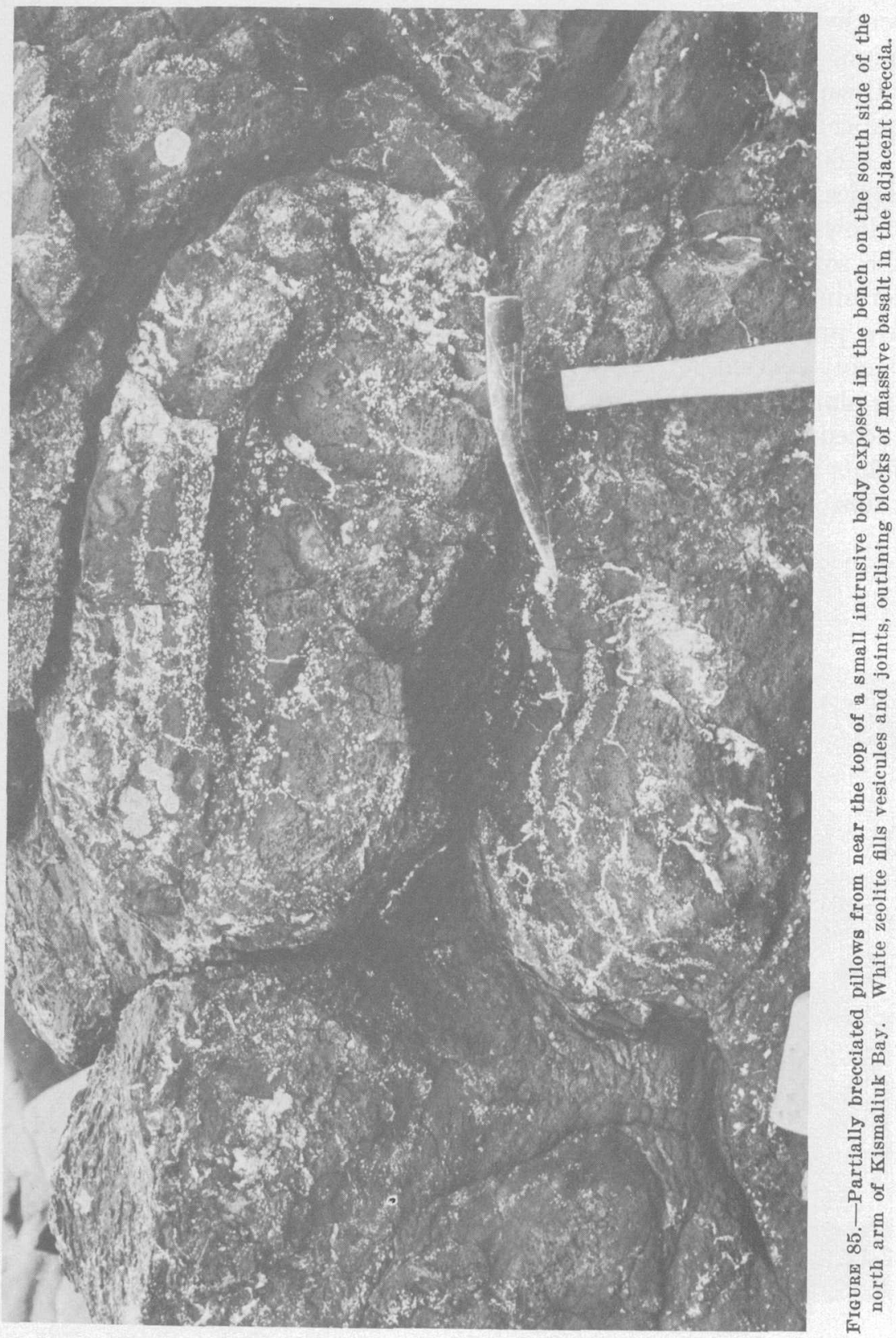


Laccolithic pods and domes, a few demonstrably attached to sills, are conspicuous large members of the family of structures formed on southwestern Unalaska Island. Segmentation of sills into major and minor structures is illustrated in figure 86. One layer shows a large sill separated into a banded dome and two pods, all surrounded by imperfectly formed pillows.

A 600-foot horizontal sheet of concentrically banded, deltoid-shaped domes, which are completely surrounded in cross section by large pillows, is present in the sea cliffs at Cape Prominence. Elsewhere on the south coast, bulges like the deltoid-shaped domes occur on the terminal or medial parts of sills. Concentric bands about 1 foot thick are present in most laccolithic masses, but banding is not always visibly concentric (figs. $84,86,87$ ). The banding may appear lobate in plan or horizontal in vertical section, and it is not limited to detached or even to deformed portions of the sills. Columnar fan joints either replace or obscure the concentric banding in some structures, particularly the domed sills. The banding consists of alter-

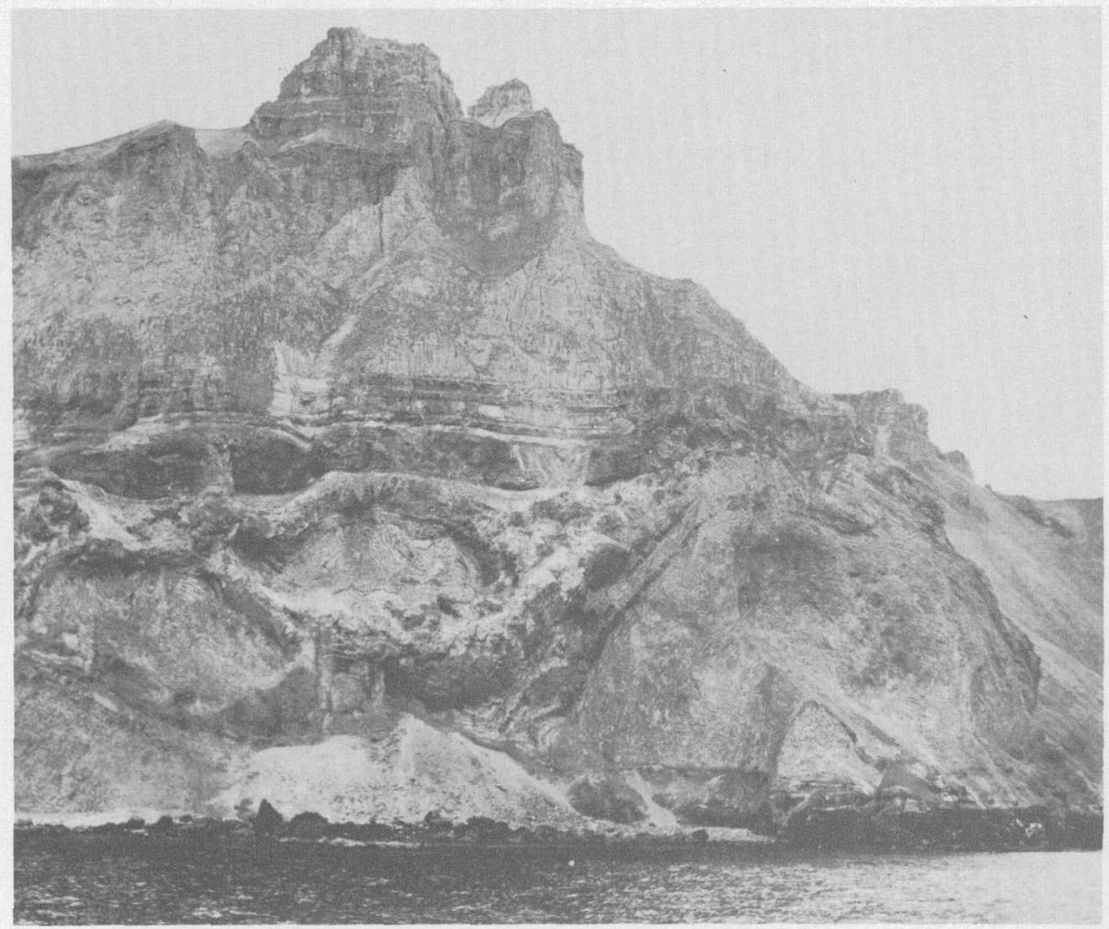

Figure 86.-Disruption of sills, Tower Point, southwestern Unalaska Island. Cliff is 1,200 feet high. The albitized (andesite?) dome and pods with strong concentric layering lie beneath partly fragmented layered argillites and an unbroken sill. Coarsebedded tuff caps cliff. 
nating reddish and greenish layers, of which the reddish layers are more resistant to erosion and project above the other layers on tidal flats (fig. 87).

\section{DIKES}

Dikes are common throughout the Unalaska formation as probable feeders of flows and intrusive pillow layers. In the northeastern part of the island, where they are unusually abundant, they form two sets. Closely spaced dikes, or multiple dikes, strike N. $70^{\circ} \mathrm{W}$. and dip steeply southwest on the rounded ridge between Summer and Agamgik Bays and on the northern end of the ridge at the head of Kalekta Bay. The second set of dikes, striking N. $45^{\circ} \mathrm{W}$. and dipping steeply southwest, are most closely spaced southwest of Lofty Mountain. In these areas dikes commonly form 75 percent of the rock, and locally, as at the end of the ridge extending into the head of Kalekta Bay, they form all of the rock. Isolated dikes of both sets are scattered throughout adjacent areas, and in the few places where dikes of the two sets occur together, those trending N. $45^{\circ} \mathrm{W}$. cut the others and are intrusive into strongly sheared, discontinuous sheets and septa of tuff breccia of the Unalaska formation. Similar dike complexes in the Hawaiian Islands mark the location of volcanic rift zones (Wentworth and Macdonald, 1953, p. 89-91, fig. 45).

The rocks of both dike sets are greenish-gray to dark-bluish-gray andesite porphyry. Some dikes are bordered by flow breccias; the

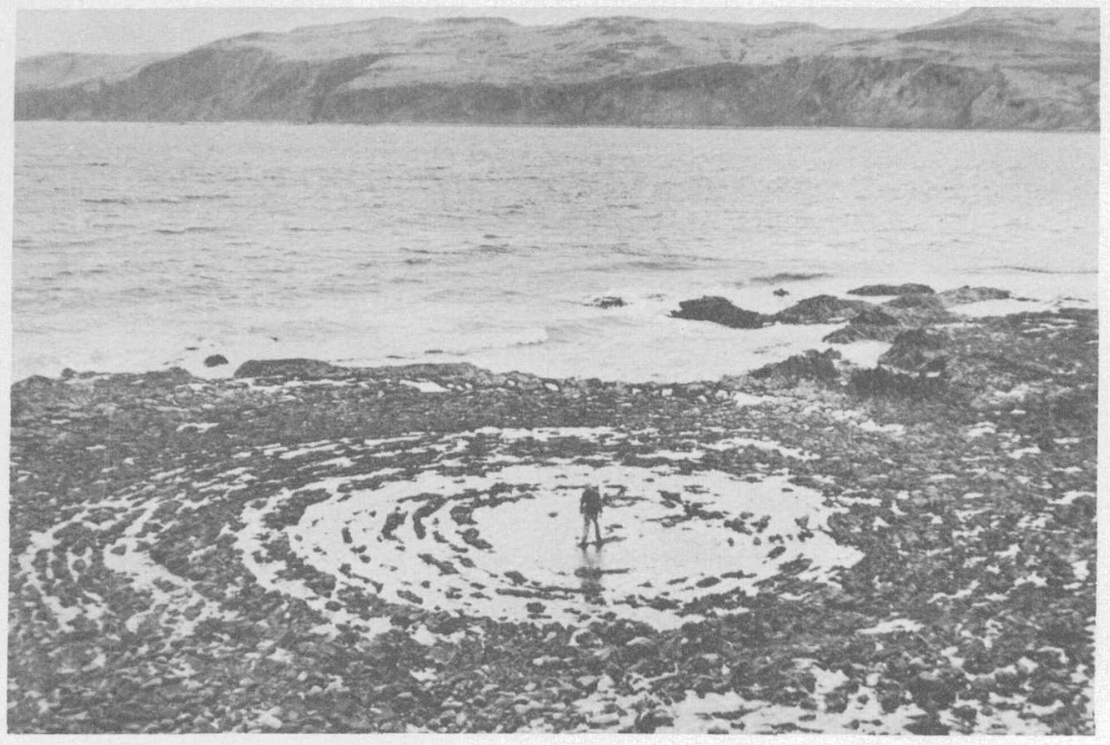

Figure 87.- Horizontal section of a layered dome on a tidal bench along the west side of Alimuda Bay, western Unalaska Island. 
northeast boundary of the Kalekta Bay dike swarm is such a zone, 300 feet wide. Many dikes contain intensely fractured zones parallel with the walls, and rounded fragments of the parent andesite are imbedded in a dense matrix of the same composition.

PETROGRAPHY OF THE UNALASKA FORMATION

The igneous rocks in the Unalaska formation are albitized andesite (spilite) and more rarely, albitized basalt and dacite. The dominant minerals are plagioclase and clinopyroxene, which generally occur as phenocrysts as well as in the groundmass. Some rocks also contain hypersthene and others common hornblende. Accessory minerals are magnetite, apatite, and rare sphene, zircon, and primary quartz. Pyrite euhedra of possible primary origin occur in some vitrophyres. Felty texture is ubiquitous and the long feldspar laths in many rocks are alined, forming a flow texture. Phenocrysts rarely exceed about 15 percent of the volume of the rock and average only about 5 to 10 percent, but in a few dikes the phenocrysts make up as much as 50 to 75 percent. Glass is a minor constituent in a few rocks, and rarely it is dominant. In many thin sections, especially of sedimentary rocks, original textures and compositions are barely discernible because the rocks are so altered. Completely recrystallized igneous and sedimentary rocks of the Unalaska formation are described on pages $622-624$.

The term "basalt" is used in this report for an igneous rock whose microphenocryst and groundmass plagioclase composition is greater than 50 percent anorthite. In the field the color of the rock was an approximate guide; if the large feldspar crystals were chalky, albitization was suspected and the distinction between andesite and basalt was not made. The composition of the groundmass and microphenocryst plagioclase was determined from extinction angles in the [100] plane, and the high temperature curve given by Tröger (1952, p. 113). The average plagioclase in the groundmass from the Unalaska formation and from other volcanic rocks on the island contains about 5 to 10 percent less anorthite than the plagioclase phenocrysts (see p. 624); hence, a rock that has a very fine groundmass or is much altered is considered a basalt if the plagioclase phenocrysts are at least as calcic as $\mathrm{An}_{60}$, especially if they are accompanied by abundant pyroxene. Names of glassy rocks are obtained by comparing their chemical analyses with analyses of similar but coarser rocks reported by Washington (1917). The original composition of some albitized rocks is estimated from unaltered cores of crystals. Compositions of most albitized rocks, however, are unknown or are estimated by comparison with the composition of nearby rocks. Petrographic descriptions are based on a study of about 220 thin sections, mostly of the igneous rocks. 
Plagioclase crystals are generally lath shaped. Stubby crystals are more common as phenocrysts than in the groundmass, are more common in basalt than in andesite, and are more common in dikes than in other igneous bodies. Normal, oscillatory, and possible reverse zoning are common, and in many crystals the zones or cores contain dusty inclusions. The crystals with dusty incluisions and possible reverse zoning do not show clear twinning, and their composition cannot be determined in this section. The effect of their omission from the composition averages is unknown. Plagioclase composition ranges from albite to bytownite, but generally is andesine or labradorite. The plagioclase of dikes is labradorite to anorthite. The clinopyroxene is either augite or diopside; those grains with pleochroism or color are recorded as augite(?) and those without are listed as augite or diopside. Hypersthene and common hornblende and magnetite appear as phenocrysts in some dilies. In one dike, quartz, biotite, and plagioclase phenocrysts occur together. Olivine occurs in the volcanic pipe on Eider Point.

\section{SPECIFIC DATA FOR ANALYZED ROCKS}

Chemical and spectrographic analyses of nine igneous rocks from the Unalaska formation are listed in table 1. General locations from which the rocks were collected are given on the following pages and detailed locations are indicated on the map.

Specimen 1 is feldspathic basalt porphyry from a dike in the Unalaska formation near Summer Bay in Unalaska Bay. It is dark bluish gray and contains phenocrysts as large as 1 millimeter. Phenocrysts compose 10 percent of the rock: 9 percent calcic labradorite, which forms embayed crystals, euhedral laths, and grains with inconspicuous normal zoning; 1 percent augite(?), which forms altered euhedra and is replaced by penninite(?); and a trace of pyrite. The groundmass has a felty texture and consists of abundant euhedral and subhedral laths of calcic andesine and scattered granules of a black opaque mineral. Alteration is moderate, producing disseminated calcite and penninite and traces of uralite and chlorite.

Specimen 9 is feldspathic basalt porphyry from the Unalaska formation $1 \frac{1}{2}$ miles northwest of Humpback Bay in Makushin Bay. It is greenish gray to grayish green and contains phenocrysts 1 to 2 millimeters long. Phenocrysts compose 15 percent of the rock: 12 percent sodic labradorite, which forms embayed crystals, euhedral laths, and irregular grains and which contains normal and oscillatory zones and zones of dusty inclusions ; 3 percent augite or diopside, which form euhedral to anhedral crystals and crystal clusters and which alter to chlorite and uralite(?) pseudomorphs; and a trace of olivine(?), which appears as chlorite and uralite (?) pseudomorphs. The groundmass has a felty to granular texture and consists of plagioclase, altered pyroxene(?), and a black opaque mineral. Alteration is moderate; chlorite and uralite(?) replace pyroxene and olivine(?).

Specimen 14 is andesite porphyry from the Unalaska formation along the shore halfway between Humpback Bay and the mouth of Glacier River in Makushin Bay. It is medium gray to medium bluish gray and contains phenocrysts 
2 to 4 millimeters long. Phenocrysts compose 10 percent of the rock; 8 percent sodic andesine, which forms embayed crystals and subhedral to anhedral laths and which contains normal and oscillatory zones and zones of dusty inclusions; 2 percent augite (?), which forms euhedral to subhedral crystals, crystal clusters, and pseudomorphs of penninite (?) ; a trace of ilmenitic magnetite, which forms subhedral to anhedral crystals and embayed crystals. The groundmass has a felty to flow texture and consists of abundant subhedral laths of sodic andesine, much pyroxene, and traces of a granular black opaque mineral. Alteration is slight; there are traces of disseminated penninite(?) and uralite(?) and veinlets of epidote and quartz.

Specimen $\mathbf{1 5}$ is andesite porphyry from a dike in the Cnalaska formation along the south shore of Kalekta Bay. It is light bluish gray to medium gray and has phenocrysts 1 to 3 millimeters long. Phenocrysts compose 20 percent of the rock: 19 percent sodic labradorite to sodic andesine, which forms embayed crystals and subhedral laths and which is zoned normally; a trace of clinopyroxene, which alters to uralite(?) and chlorite; and a trace of pyrite, which forms subhedra associated with clinopyroxene. The groundmass, which has a felty and intersertal texture, consists of abundant subhedral laths of sodic andesine, and also a trace of subhedral clinopyroxene and a granular black opaque mineral. Alteration is moderate: chlorite and uralite(?) are common, and calcite forms disseminated crystals and veinlets.

Specimen 19 is pyrite-bearing dacite vitrophyre from the Unalaska formation 1 mile east of Chernofski Harbor. It is black and contains plagioclase phenocrysts 1 to 4 millimeters long. Phenocrysts compose 5 percent of the rock: 2 percent calcic labradorite, which form embayed crystals, euhedral laths and stubby crystals, and fragments, and which have oscillatory zones and apatite inclusions; 1 percent euhedral augite (?) ; 1 percent euhedral hypersthene; and a trace of euhedral to subhedral ilmenitic magnetite. Microlites of plagioclase are common and of apatite rare. The groundmass is a perlitic glass, which contains a few small chlorite(?) spherulites.

Specimen 20 is dacite vitrophyre from the Unalaska formation at Buttress Point, 10 miles southwest of Kuliliak Bay. It is black and has plagioclase phenocrysts as large as 2.5 millimeters, and amygdules with a diameter of 1 to 4 nillimeters. Phenocrysts compose 5 percent of the rock: 4 percent sodic andesine, which forms embayed crystals and euhedral to subhedral laths and siubby crystals, and which has normal zones and apatite inclusions; a trace of subhedral hypersthene; a trace of subhedral augite(?); and a trace of subhedral to euhedral ilmenitic magnetite. Microlites of plagioclase are common, and of apatite rare. The groundmass is glass, which is slightly devitrified and altered to chlorite(?) and contains 1 percent zeolite(?)-filled amygdules.

Specimen 22 is albitized andesite(?) porphyry from the Unalaska formation. $1 \frac{1}{2}$ miles south of Hive Bay and about halfway between Staraya Bay and Udagak Strait. It is medium-light gray to medium gray and has chalky plagiociase phenocrysts 1 to 5 millimeters long. Phenocrysts compose 5 percent of the rock : 4 percent albite, which forms euhedral to subhedral laths and stubby crystals having apatite inclusions; and 1 percent euhedral to anhedral magnetite. The groundmass is mottled and indistinct. Alteration is intense: alhite and kaolin are pervasive; calcite is common and forms irregular patches near albite clusters; uralite(?) is present; and quartz is rare and forms scattered grains on crudely alined pods.

Specimen 23 is albitized dacite (?) porphyry from the Unalaska formation at Hive Bay halfway between Staraya Bay and Udagak Strait. It is light gray 
and contains chalky plagioclase and ferromagnesian phenocrysts 1 to 2 millimeters long. Phenocrysts compose 1 percent of the rock, consisting of subhedral laths of albite with apatite inclusions. The groundmass has an indistinct intersertal texture and consists of abundant subhedral laths of albite, a trace of a granular black opaque mineral, and a trace of quartz that may be primary. Alteration is intense, albite and kaolin are pervasive and abundant, quartz is common and intersertal; calcite is common and forms scattered patches, especially near altered ferromagnesian minerals; and chlorite and uralite (?) are common alteration products of the ferromagnesian minerals.

Specimen 24 is albitized dacite porphyry from one-half mile west of Buttress Point and 101/2 miles southwest of Kuliliak Bay. It is brownish gray and has chalky plagioclase and ferromagnesian phenocrysts 1 to 2 millimeters long. I'henocrysts compose 1 percent of the rock, consisting of euhedral to subhedral laths and stubby crystals of albite with apatite inclusions and a trace of subhedral magnetite. The groundmass has an in distinct intersertal texture, consisting of abundant subhedral laths of albite and much interstitial altered glass, as well as traces of anhedral clinopyroxene, a granular black opaque mineral, and interstitial quartz that may be primary and that has apatite inclusions. Alteration is intense; albite and kaolin are pervasive and abundant; quartz is common and interstitial ; and there are traces of chlorite and uralite (?) altering clinopyroxene.

The major oxides of the analyzed rocks are plotted against silica in the variation diagram of figure 88 . In general, these rocks are among the more silicic and alkalic of the suite from Unalaska Island. Specimens 22, 23, and 24 are completely albitized and cannot be compared directly with the unaltered rocks, though they are from sills and deltoid-shaped domes of the Unalaska formation. specimen 1 , which contains the least silica of the entire suite, is from a dike in the Unalaska formation; it is highly aluminous (note the normative corundum, table 1) and comparatively low in ferromagnesian minerals. It may represent an igneous episode unrelated to that which produced the rocks of the Unalaska formation. In the volcanic rocks of Unalaska Island the average content of boron, barium, scandium, and strontium is higher, and the average content of chromium and copper is lower than in similar rocks reported by Goldschmidt (1954, respectively, p. 281-282, 252, 305, 245, 548, and 179).

\section{ALTERATION}

Rocks of the Unalaska formation have been altered during possibly two episodes. The earlier episode, perhaps penecontemporaneous with deposition, has resulted in the development of abundant spilitic rocks. Superposed upon this sodium enrichment, or occurring with it, is a hydrothermal alteration most probably associated with the introduction of granodiorite plutons.

Spilites are common in all parts of the Unalaska formation except between Kalekta Bay and Beaver Inlet in the northeastern part of the island. The "fresher" appearance, poorer induration, and the absence of pale colors associated with albitization of rocks in this northeastern area suggests that these rocks may be younger than those of the rest of the formation, but the altered and unaltered types apparently are .laterally gradational and probably are different alteration facies. 

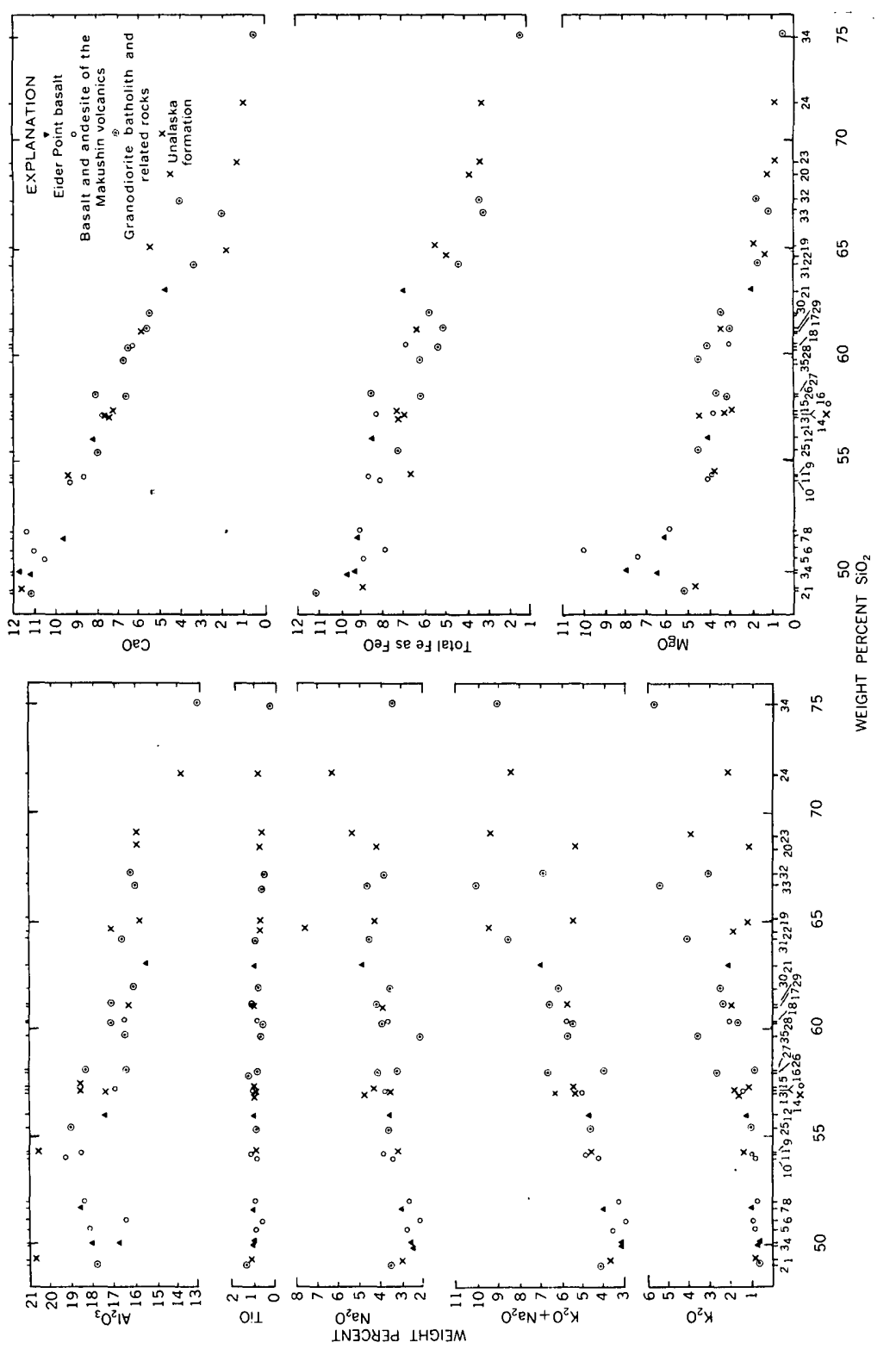

odse af 
About one-half of the thin sections of the Unalaska formation show albite with kaolinitic alteration. These rocks are lighter colored than their nonspilitic counterparts, and the plagioclase phenocrysts have a chalky appearance. Several thin sections contain both albitized and relict calcic plagioclase. Some of the phenocrysts contain clear patches of andesine or labradorite in an irregular network of kaolinitic and more sodic plagioclase, showing incomplete albitization.

Hydrothermal alteration, which is responsible for the widespread distribution of chlorite, uralite, and epidote (fig. 89) in the rocks of the Unalaska formation, is far more conspicuous. Some of the granodioritic rocks show similar alteration, but the Makushin volcanics and the younger volcanic rocks are notably free of these secondary minerals.

Chlorite is usually pseudomorphous after amphiboles or pyroxenes and commonly includes several different compositior al varieties. As many as three varieties of chlorite occur in some thin sections. Altered glass generally contains abundant chlorite, some of which occurs as veins and cavity fillings or is interstitial. Most of the chlorites show low birefringence, but some have anomalous blue, violet, or bluishgreen interference colors. Uralite is also a common alteration product of ferromagnesian minerals and is altered in turn to chlorite. Epidote is more restricted and was found only within 5 miles of the granodiorite plutons, except for a single occurrence at the southwest end of the island (fig. 89). Generally epidote is granular; it is scattered widely, but is subordinate to chlorite except near pluton contacts.

Other alteration products include sericite, kaolinite(?), pyrite, quartz, calcite, and less common secondary minerals such as leucoxene, hematite, limonite, and possibly some sphene. Kaolinite(?) is a more common alteration product of feldspar than is sericite. Some of the pyrite disseminated in igneous rocks and that which occurs as phenocrysts in glassy pillow lavas is possibly primary, but the pyrite that forms pods or veins is clearly secondary. About half of the thin sections examined show secondary quartz as veinlets, vug fillings, or as a replacement. Material between pillows is commonly rich in secondary crystalline and cryptocyystalline quartz. The reported frequency of primary quartz may be underestimated because of the difficulty in recognizing it when secondary quartz is abundant. The amount of secondary silica in the extremely fine, chertlike argillites may have been underestimated because the determination of minerals in thin sections is doubtful. Calcite is less abundant than quartz and occurs as veinlets and pockets, and rarely as pseudomorphic replacements. Hematite and limonite are generally found where the pyrite content is high, and many of the bright oxidation colors along sea cliffs mark 
pyrite-rich rock, which is commonly confined to zones suggestive of veins or faults.

Locally along the contacts of the large intrusives with the Unalaska formation, there is a zone of biotite-hornblende-pyroxene hornfels, some of which is sheared. Patches of these minerals, and in places also epidote, cut hybrid rocks containing relict volcanic texture. Within and near the roof of the largest pluton a few veins of tourmaline were noted.

Some of the common hydrothermal alteration minerals are distributed in concentric belts around the batholiths, as shown in figure 89 . Extreme alteration of the host rocks may be represented by mobilized border rocks discussed below. Near the contact with the batholith, scattered tourmaline crystals and the biotite-hornblende-pyroxene hornfels mark a high- to medium-temperature zone which commonly contains more than 20 percent secondary minerals. Farther outward, but within 5 miles of the nearest batholith, is the medium- to lowtemperature epidote zone in which the rocks contain about 10 percent of these alteration minerals. Beyond this distance the rocks rarely contain more than 5 percent of combined chlorite and uralite.

FAUNA AND AGE

Fossils were found in road and building cuts immediately east of Unalaska Lake, 1 mile from the dock area in the village. I'elecypods were identified by F. S. MacNeil as $M y a$ cf. $M$. truncata, which has a wide range in the Tertiary. Bones and teeth were identified by G. E. Jewis as parts of a desmostylid sirenian-a relative of the sea cows, which probably differed from them in having legs instead of flippers. The most significant specimen is a low-crowned cheek-tooth fragment with typical desmostylid cusps. The fragments probably are referable to a single animal of the genus Cornvallius, which is generally indicative of an early Miocene age, although identification as Desmostylus is possible. *** "Cornwallius lived in shallow coastal littoral, deltaic, lagoonal or estuarine waters, and fed on shellfish," according to G. E. Lewis. F. S. MacNeil states that the present-day representatives of the clam "Mya cf. $M$. truncata live in intertidal depths for a few fathoms below low tide." Perhaps Cornwallius found Mya a succulent morsel. Mya indicates a cold-water environment, probably very much as the Unalaska Island waters are today.

Cornwallius is known in the Sooke formation of the Puget Sound area and in the San Gregorio formation of Baja California. These formations, or others correlated with them, are considered to be lower Miocene by some (Lewis, written communication, Oct. 14, 1954) but upper Oligocene according to others (Durham, 1950, p. 26, 34-36; Clark and Arnold, 1923, p. 125). Desmostylus is generally considered 
to be indicative of Miocene age, but in Japan it may occur in the upper Oligocene as well (Onodera, S., 1957, p. 238-253; Minato, M., Matsui, M. Ishhii, J., 1957, p. 308-316).

F. M. Byers reports (oral communication) pelecypods which have not been identified from a locality about 11/2 miles south of Pyramid Peak near Unalaska village.

In the vicinity of the village the Unalaska formation is of probable early Miocene age; elsewhere on the island the nonfossiliferous rocks of the formation are possibly middle or early Tertiary; the older age is included because the fossiliferous rocks are possibly high in the Unalaska formation.

On the geologic map of Alaska, Dutro and Payne (1957) show the rocks herein called Unalaska formation as part of a generalized unit which is of questionable Mesozoic age in this area. This age was based on information available before the discovery of the desmostylid teeth. The Mesozoic and Tertiary volcanic rocks shown north of Beaver Inlet on this map are now known to be merely unaltered representatives of the Unalaska formation (see fig. 89).

\section{ENVIRONMENT AND ORIGIN}

The finely laminated argillaceous and siliceous rocks probably accumulated in deep basins, for the great uniformity and continuity of the laminae suggest quiet conditions of sediment accumulation. A similar environment is proposed by Bramlette $(1946$, p. 34-35) for the layered siliceous rocks of the Monterey formation of California, which resemble in many respects the finely layered rocks of the Unalaska formation. Klienpell $(1938$, p. 17) further suggests that portions of the Monterey formation were deposited at depths as great as 3,000 feet.

The abundance of coarse clastic rocks on northern and northeastern Unalaska Island, and several fossils which are shallow-water forms, probably indicate a near-source environment. The persistence and thickness of the conglomerate zone along the upper reaches of the Shaisnikof River suggest a beach deposit or a combination beach and submarine talus deposit.

Physical conditions during formation of the pillow structures and deltoid-shaped domes are uncertain, but mixing of sills with wet muds probably played a major role. Normal-sized pillows and larger pods or pillows of magma were kneaded and folded as the whole mass moved; during such movement mud was folded into them and argillite was dragged into the pillow layers. The breccia with fist-size pods at Cape Aiak may be a submarine flow breccia, perhaps a special form of the more common pépérite (Macdonald, 1939, p. 329) that retained its mobility until after the bulbous mass was injected. $58053 \overline{2} 0-61 \cdots$ 
Magmas moving on a sheet of submarine muds might be too heavy to be supported as flows and would sink, forming pods of all sizes by fragmentation of the viscous material. Or the magmas could spread laterally before reaching the mud-sea interface, and form tongues and pods in the mud. Budding above sill-like bodies formed some pillow structures and possibly some detached domes. The immiscibility of magma and mud, with the early development of a skinlike cooling surface on the budding magma, may help to explain the tendency for detachment and isolation. Deltoid-shaped domes may be laccolithic intrusives, or sills completely detached from the parent mass. Motion of the magma, indicated by brecciated contacts, pépérites, and deformed pillows, was a constant and perhaps necessary element in the formation of the pillows and other bulbous structures.

The regular distribution of oxides with respect to silica in the variation diagram, figure 88 , suggests that one parent magma was the source of all volcanic and plutonic rocks on the island.

The origin of spilites on Unalaska Island may be twofold: some spilites probably are hydrothermal; others may have been altered during deposition. That the spilites originated from a sodic magma is doubtful, for nonsodic ferromagnesian minerals occur with albitized plagioclase. Those dikes which are albitized must have been altered much later than any diagenetic alteration of the rest of the Unalaska formation. As the degree of hydrothermal alteration (chloritization and uralitization) increases near some dikes, some albite was probably introduced hydrothermally also. For these reasons, too, a hydrothermal origin of most or all spilites on the island seems slightly more probable than does a diagenetic one, hence albite alteration is shown with other hydrothermal minerals on figure 89. However, the widespread, somewhat spotty distribution of spilites on the southwestern end of the island, away from the largest pluton, and their close association with pillow structures and related submarine volcanic forms still leave room for an explanation considering diagenetic spilitization. No diagnostic criteria are available to determine the relative importance of these two origins of sodium enrichment; we cannot even be certain that both were operative on Unalaska Island.

It is further possible that spilitization was due to other processes. For instance, the sodium-rich fluid which effected spilitization may have been derived from connate water trapped in submarine sediments and volcanic rocks. Later plutonic invasions may have mobilized this fluid and enabled the cold feldspars to become albitized.

The chlorite-uralite-epidote alteration of the Unalaska formation is interpreted as a widespread hydrothermal reaction to both connate 
EXPLANATION

INTENSITY AND DOMINANT
MINERALOGY OF ALTERATION

TIMING

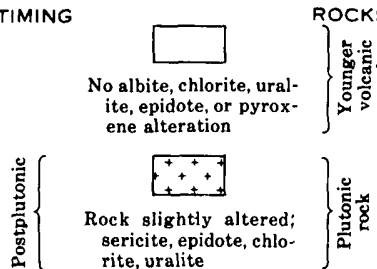

rite, uralite

בั้

Rock severely altered

Rock severely altered;
hornfels-biotite, am

phibole, pyroxene

Thickness and continu

ity exaggerated

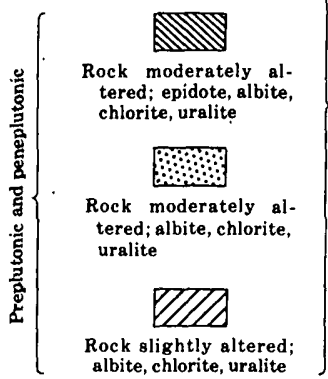

albite, chlorite, uralite

Contact

Dotted where concealed

Fault

Dashed where approximately located, dotted where concealed

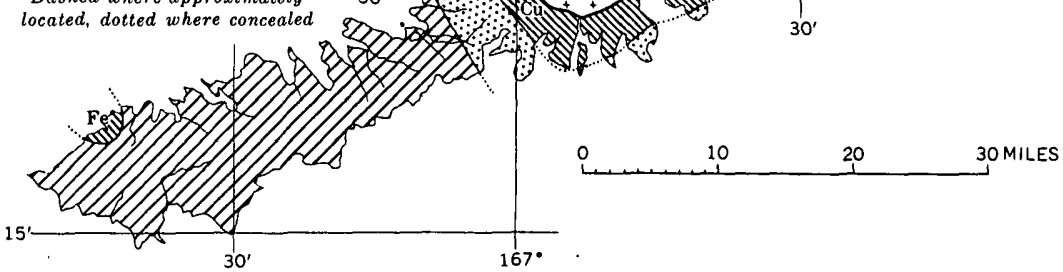

FIGURE 89.-Alteration and mineralization on Unalaska Island.

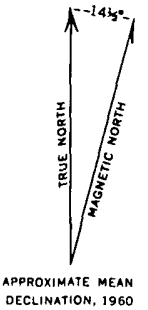

DECLINATION, 1960

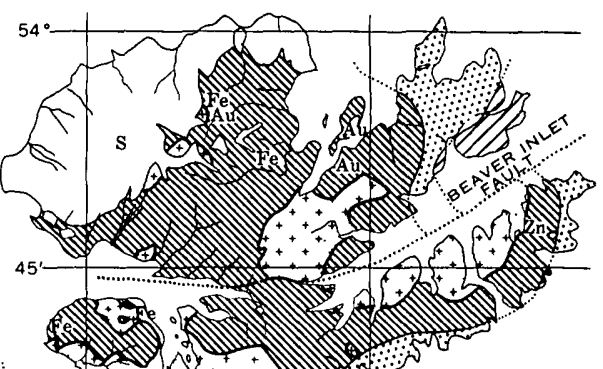

$$
\begin{array}{ll}
\mathrm{Au} & \text { Gold } \\
\mathrm{Cu} & \text { Copper sulfides } \\
\mathrm{Fe} & \text { Iron sulfide } \\
\mathrm{S} & \text { Sulfur } \\
\mathrm{Zn} & \text { Zinc sulfide }
\end{array}
$$

fluids and fluids introduced by the granodiorite batholiths prior to the last stage of their emplacement. Alteration zones, marked by secondary mineral assemblages as well as by secondary mineral abundance, are symmetrical about the batholiths and progressively of higher grade and intensity toward them. The maximum hydrothermal alteration thus coincides with the source of maximum available energy. Rocks of the batholith were deuterically altered, and perhaps fluids involved in this late alteration also escaped into the host rocks. 


\section{GRANODIORITE BATHOLITH}

FUELD RELATIONS

Three small batholiths and 25 smaller plutons ranging in size from sills and dikes 10 feet wide to stocks 4 miles wide have been studied. The three small batholiths are: Shaler pluton, centered on the Shaler Mountains in the south-central part of the island; Beaver pluton, south of Beaver Inlet; and Captains pluton, between Captains Bay and Erskine Bay. The northern part of the Shaler pluton between Skan Bay and Anderson Bay is typical of the plutonic suite and was studied in detail; about half of the 263 thin sections of plutonic rocks are from this area.

The topographic forms developed on the plutonic rocks are similar to those on the Unalaska formation which they intrude, but the volcanic rocks of the Unalaska formation generally produce jagged high ridges, whereas the batholithic rocks erode to rounded buttresses and more smoothly textured landscapes (fig. 90). Where homogeneous granodiorite is exposed at the shoreline, layers of characteristic dark- and light-weathering coloration are produced at water level. The volcanic rocks and the less homogeneous plutonic rocks show no distinctive shoreline weathering.

The contacts of the large plutons are generally very steep to vertical. In the Skan Bay-Naginak Cove area, however, many contacts are horizontal or gently dipping. The general attitude of this contact, despite all the irregularities, is nearly horizontal, and this contact is the roof of the northern part of the pluton.

Schistose or gneissic rocks form a narrow vertical zone along the southern margin of the Shaler pluton-at least from Johnson Cove to Raven Bay and possibly to Pumicestone Bay-and in the eastern half of the 3600 Mountain pendant. At Johnson Cove the schistose zone is about 100 yards wide, strikes N. $70^{\circ} \mathrm{E}$. and is nearly vertical; the schistosity within the zone strikes N. $50^{\circ} \mathrm{E}$. and dips $65^{\circ} \mathrm{SE}$. If magma motion produced the dynamic metamorphism at this portion of the contact, then this combination of attitudes suggests that in this area the magma moved upward and from west to east. In an outcrop about one-half mile southwest of the summit of 3600 Mountain, a recrystallized volcanic agglomerate has inclusions flattened in the plane of the nearly vertical schistosity and elongated downdip; this lineation, presumably an "a" lineation, suggests that magma movement was nearly vertical. Forceful intrusion of the magma must be inferred locally from these relationships, but most other information suggests passive emplacement: The contacts of the plutons, for example, though noticeably discordant, are seldom marked by drag of bedding in adjacent wall rocks. This abrupt 


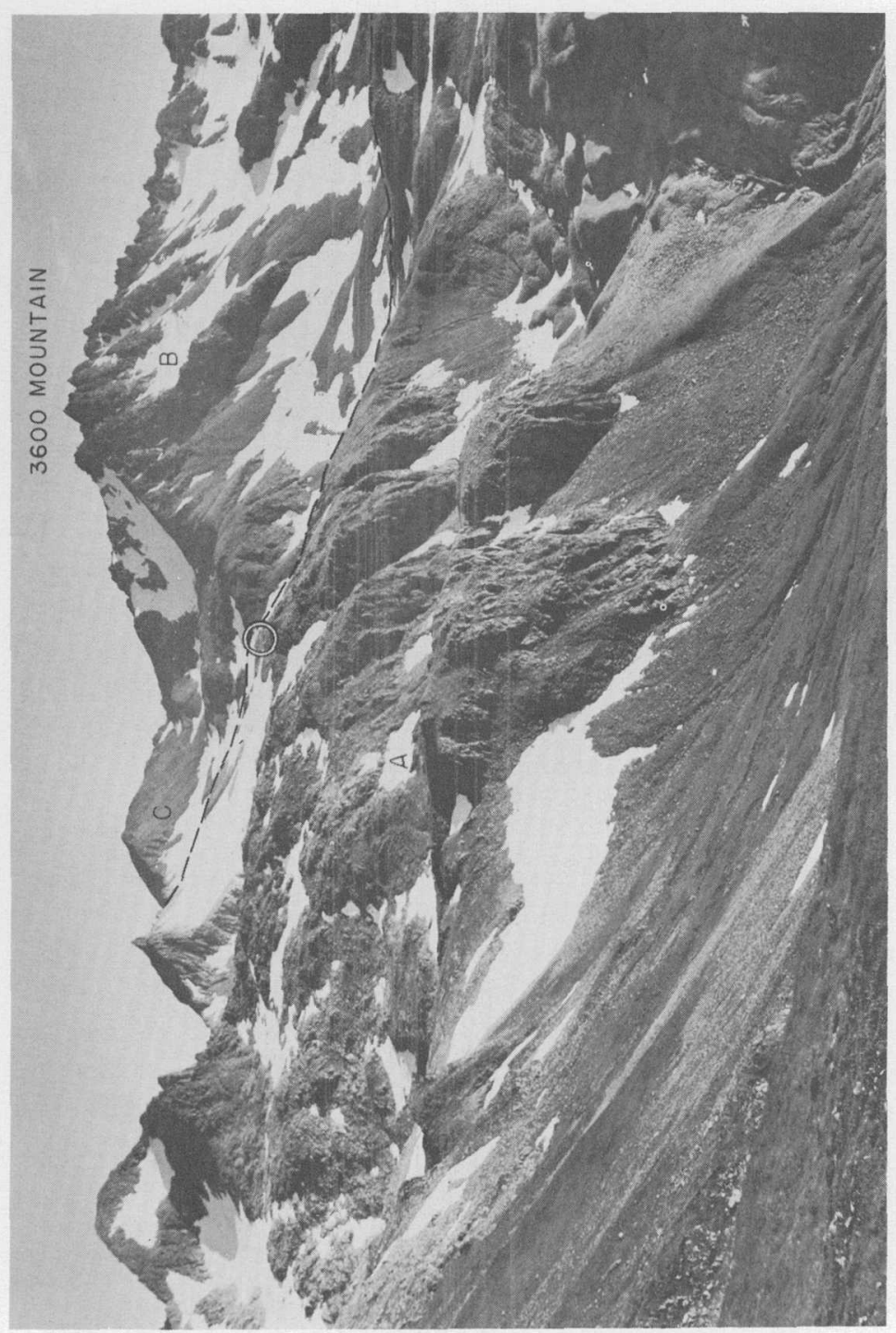

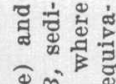

舫

a

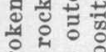

능 형

8 月 웡

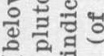

जा

藏范泀

a

正密

ชี

$\infty 0$ 呵

हี สํํㅀ

요요

+ 덩

สํ ถั

द्व

궁

岁徎

음

들 흠

吅

크웅

항ㅎㅇ का

․

๑)

연

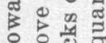

$+: 0$

구 స

며

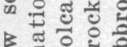

일

के

4 政

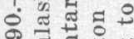

由

苑被

密 
discordance is especially well exposed between Usof Bay and Raven Bay, on the eastern side of Three Island Bay, and in the southern half of Udagak Strait. In the Skan Bay-Naginak Cove area the Unalaska formation dips gently northwestward both near Cape Starichkof and in the unmetamorphosed portions of the 3600 Mountain pendant. It is nearly horizontal in the ridge between Cape Starichkof and Anderson Bay. The roof pendants are not infolded remnants; the randomly undulating contact owes its shape to joint control of stoping or assimilation rather than to folding of the overlying rocks.

In the interiors of the three small batholiths, widely spaced parallel joints are separated by massive unjointed rock (fig. 91). Some large joints or faults extend beyond the plutonic rocks (p.656, pl. 77). The heterogeneous border rocks are characterized by very irregular fracture patterns, with near-random joints and joint sets, down to handspecimen size without large intervening areas of unjointed rock (fig. 92). Probably the relative homogeneity of composition controlled the mode of fracture.

The age of all large coarse-grained plutons and most small coarsegrained plutons is probably younger than early Miocene and older than middle Pleistocene, as rocks of the Captains pluton crop out $11 / 2$ miles upstream from the altered rocks at the desmostylid locality and the Makushin volcanics uncomformably overlie quartz diorite stocks in the Makushin massif area.

\section{PETROGRAPHY OF THE BATHOLTTH}

Most of the plutonic rocks of Unalaska Island have hypidiomorphicgranular textures, but a few are porphyritic. The wallrocks bordering the large plutons are schistose or hornfelsic. A summary of the mineralogy of all holocrystalline rocks of Unalaska Island is given in plate 76. Johannsen's (1950, v. 1, p. 141-161) terminology for igneous rocks is followed throughout, even for the recrystallized wallrocks, to facilitate direct comparison of rock compositions-except that Johannsen's tonalites are called quartz diorites, and his adamellites, quartz monzonites. Mineral percentages given are visual estimates; they are believed to be accurate within 1 to 5 percent of any one constituent.

The principal felsic minerals of the holocrystalline rocks of Unalaska Island are plagioclase, potassic feldspar, and quartz. The plagioclase ranges in composition from albite to anorthite; most is unzoned, but much exhibits progressive oscillatory zoning from wide calcic cores to thin sodic rims. The range of average composition of individual plagioclase crystals can be large within a single rock 


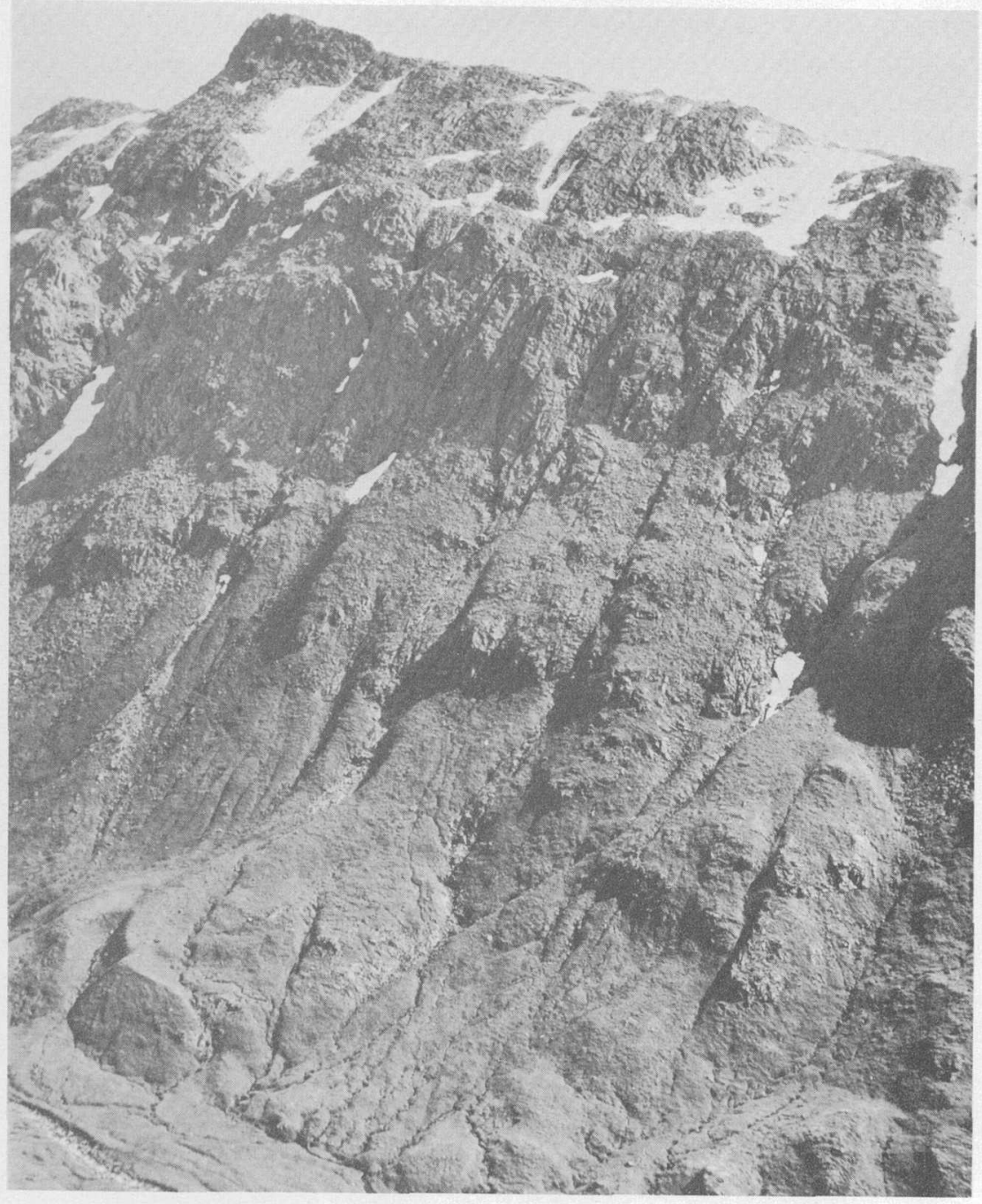

Figure 91.-Joint pattern in homogeneous central granodiorite of Shaler pluton, looking south from south shoulder of 3600 Mountain. Relief is 2,600 feet. Joints are 50 feet to several hundred feet apart; the massive rock between is unjointed except for irregular face fractures of outerops.

(fig. 93), and for this reason the plagioclase composition is given in plate 76 only for specimens for which determinations on six or more grains have been averaged. Composition of plagioclase in the plutonic rocks was determined by measurement of extinction angles of albite twin lamellae in MP sections $\perp$ to 010 (Tröger, 1952, p. 113, upper diagram, low temperature curve). Practically all the potassic feldspar is orthoclase, with large optic angle and no cross-hatch twin- 
ning. All potassic feldspar is interstitial and crystals are usually anhedral to subhedral; the common appearance in thin section is that of an irregularly branching mass with concave outward surfaces. Some orthoclase crystals are developed in former miarolitic cavities, which were subsequently filled with quartz. Micropegmatitic intergrowths with quartz are common; feathery perthite is commonly developed. Orthoclase or potassium-rich alkalic feldspar is commonly

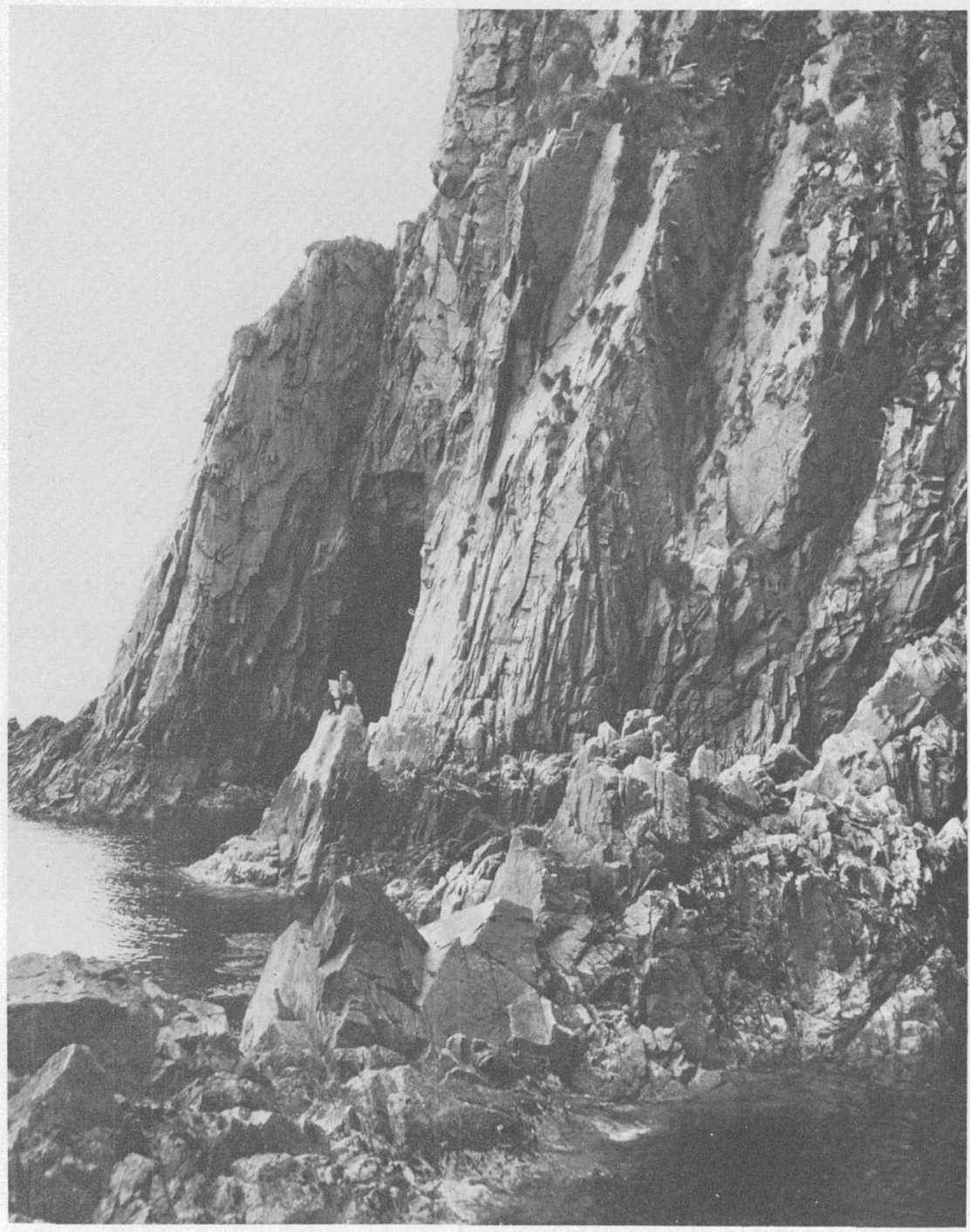

Figure 92.-Joint pattern in inhomogeneous border rocks of 'Shaler pluton on Kof Point. Rocks are intimate mixtures of gabbro, granite, quartz diorite, quartz monzonite, and granodiorite, broken by discontinuous closely spaced joints of many orientations. 

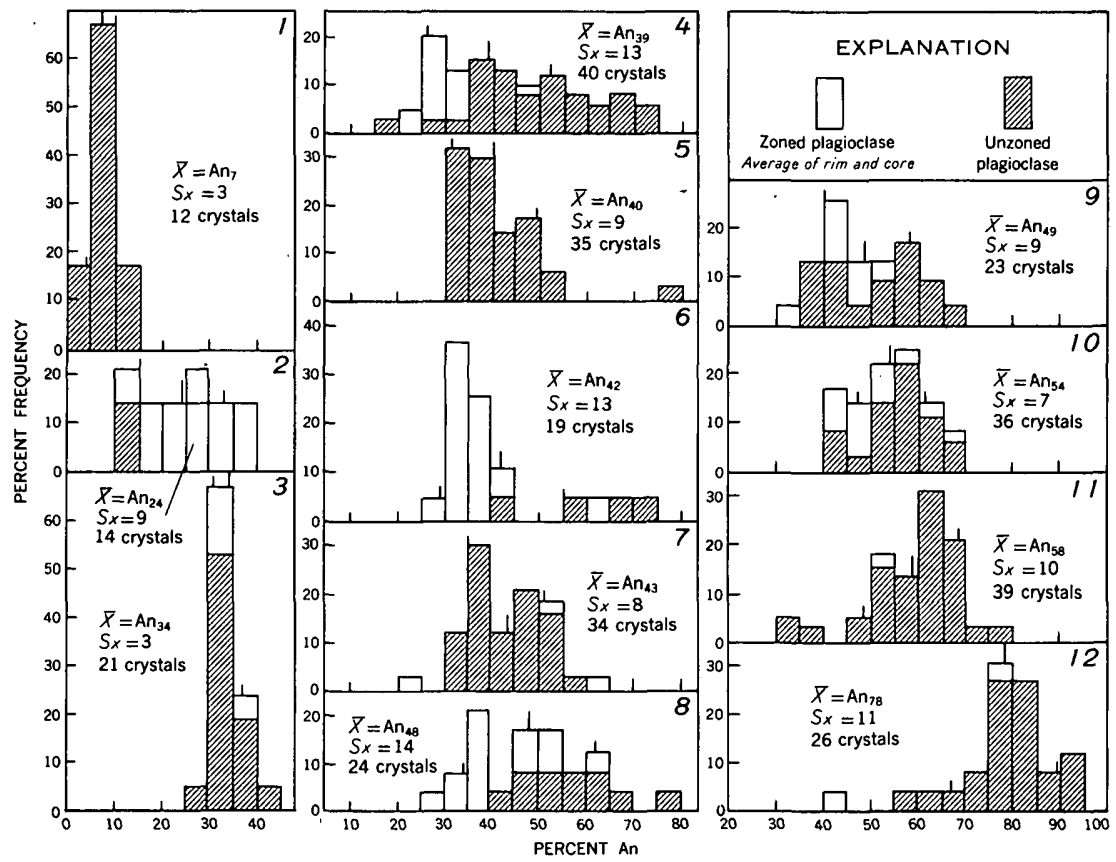

Figure 93.-Percent-frequency distributions of the average percent anorthite in plagioclase crystals of typical holocrystalline rocks of Unalaska Island. $\overline{\mathbf{X}}$ is arithmetic mean for each rock; $S_{\approx}$ is standard deviation for each rock.

optically continuous with the albite rims of plagioclase. Except in a few quartz porphyries having subhedral to enhedral quartz phenocrysts, most of the quartz is late and occurs as anhedral crystals with a mammillary form. Primary muscovite was observed in three rocks, and zeolites, probably thomsonite and stilbite, form up to 5 percent of the groundmass of the sills on the southwest end of the island.

In figure 93 the plagioclase composition is shown diagrammatically for the following rocks from the Shaler pluton, as represented by designated chemical analyses: 1, leuco albite quartz monzonite from marginal aplitic body near the south-central contact of the 3600 Mountain pendant, analysis $34 ; 2$, leuco granite from a marginal aplitic body at the north contact of the 3600 Mountain pendant, near the contact indentation southwest of the head of Naginak Cove; 3, granodiorite from northeast of the head of Raven Bay, analysis 29; 4, granodiorite from the south shore of large lake north of 3600 Mountain pendant, analysis 33 ; 5 , granodiorite from shore bench south of mouth of stream emptying into north side of Skan Bay, analysis $26 ; 6$, granodiorite from sea cliff outcrop 2 miles west of Tarasof Point, which intrudes gabbro represented by specimen 11 (below) ; 7, granodiorite from head of north arm of Skan Bay; 9, 
quartz diorite from near contact 3 miles southwest of Tarasof Point; 10, quartz gabbro from near contact $23 / 4$ miles southwest of Tarasof Point, analysis 25 ; 11, gabbro from sea cliff outcrop 2 miles west of Tarasof Point, which is intruded by granodiorite represented in rock 6 (above). Rock 8 is a granodiorite from the Captains pluton, west of the stream 1 mile southwest of the head of Captains Bay, and rock $1 \bar{z}$ is a gabbro from the Cape Aiak sill 3 miles north-northeast of southern tip of Cape Aiak, analysis 2. In plate 76, aplites, large plutons, small: intrusive bodies, and recrystallized wallrocks are represented, respectively, by approximately $17,163,35$, and 43 specimens, except in distributions dealing with plagioclase composition where they are represented, respectively, by approximately 13,158 , 29 , and 56 specimens. In plate 76 , amphibole percentages include amphibole altered from pyroxene.

The principal mafic minerals of the holocrystalline rocks of Unalaska Island are orthopyroxene, clinopyroxene, amphibole, biotite, and magnetite-ilmenite. Olivine is present (to 8 percent) in only a few rocks. The orthopyroxene, hypersthene where determinable, is invariably euhedral and acicular, and may be partially or completely replaced by bastite. The clinopyroxene, generally augite, is anhedral to subhedral (rarely euhedral and stubby) and poikilitic, and is generally partly replaced by amphibole. Secondary amphibole (uralite) may be hornblende or hornblende-actinolite or actinolite-tremolite (pleochroism in light greenish tints or colorless). Primary amphibole ranges from anhedral to euhedral and from massive to fibrous, and is usually hornblende or hornblende-actinolite pleochroic in green, bluish green, olive green, brownish green, or brown. Riebeckite(?) occurs in one hornfels in vuglike spaces also containing sodic oligoclase and pyrite. Biotite is usually subhedral to anhedral and frequently is associated with magnetite-ilmenite. Magnetite-ilmenite is universally present and is always anhedral. Leucoxene alteration is developed sparingly, which suggests that magnetite is dominant over ilmenite.

Accessory constituents of plutonic rocks of Unalaska Island are: anhedral titanite (sometimes veinlike); euhedral apatite (rarely anhedral) ; anhedral allanite (commonly in veins or interstitial and always metamict) ; euhedral tourmaline; euhedral zircon; anhedral pyrite (commonly in veins); anhedral chlorite (penninite); anhedral to subhedral epidote-clinozoisite; hematite; rutile, as submicroscopic needles in feldspar and stubby euhedra in titanite; anhedral calcite; and anhedral chalcopyrite (?). The occurrence of a dusky green spinel in one border hornfels from Blueberry Bay has been confirmed by $\mathrm{X}$-ray powder studies. A mineral believed to be prehnite is present 
in several rocks as elongate, radiating aggregates which dilate biotite cleavages, an unusual occurrence similar to that described by Wells and Bishop (1955, p. 154, figs. 3, 5) in diorite from the Channel Islands.

Probably 60 to 80 percent of the coarse-grained rock at the ground surface of Unalaska Island is granodiorite (pl. 75, fig. 86), and even this figure probably increases rapidly with depth. Only 38 percent of the 263 rocks studied fall in the granodiorite category (see table 2), but the volumetrically minor aplites, small intrusive bodies, and hornfelses bulk disproportionately large in this table. However, many rocks besides granodiorite are associated with the Unalaska coarsegrained intrusive complex (fig. 94).

Holocrystalline rocks occur in varieties as felsic as leucogranite and kalialaskite and as mafic as melagabbro and hornblendite; there are also many intermediate types. Except for the tabular bodies of aplite and pegmatite, these rocks grade imperceptibly into each

TABLE 2. Incidence of studied holocrystalline rock types on Unalaska Island (Johannsen nomenclature)

[Johannsen (1950) igneous rock names applied to recrystallized wallrocks to facilitate direct comparison igneous rock compositions]

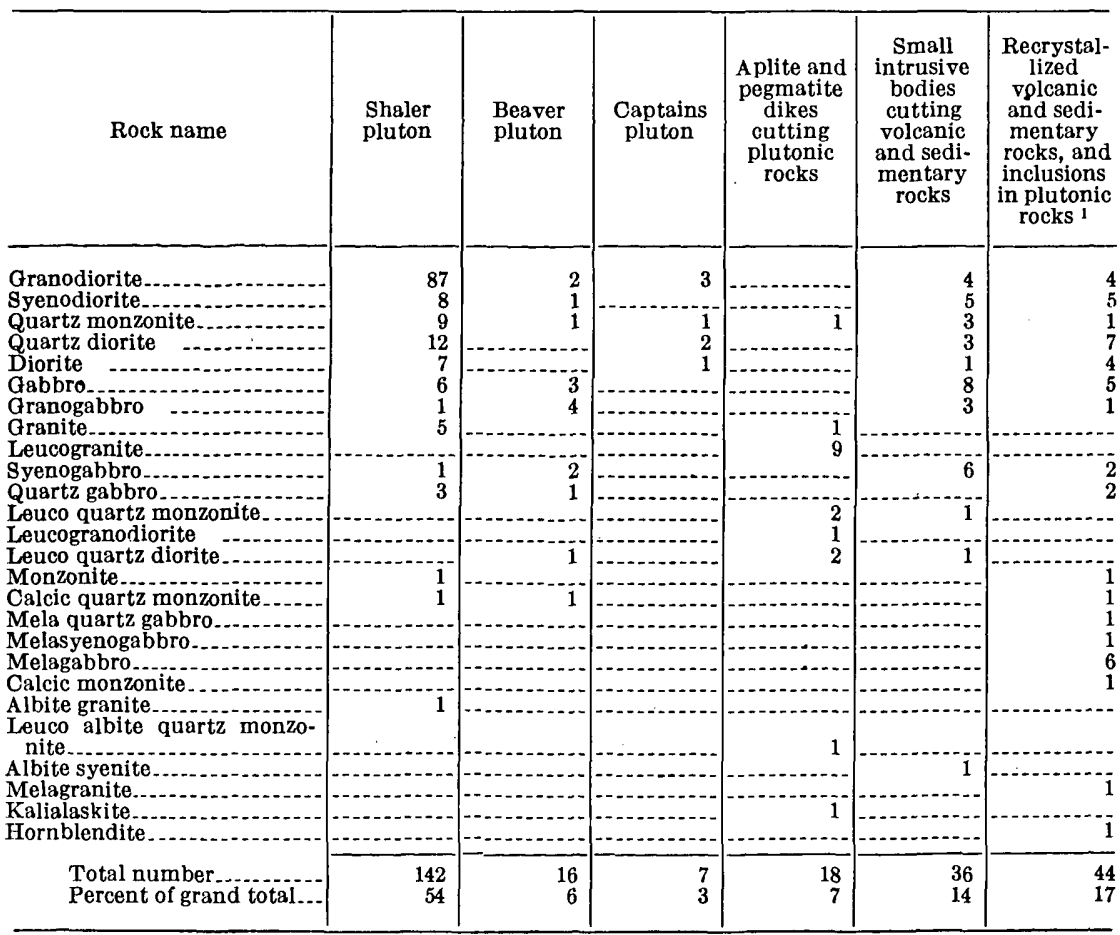

\footnotetext{
1 Includes 30 border hornfels, 6 border schists and gneisses, and 8 inclusions.
} 

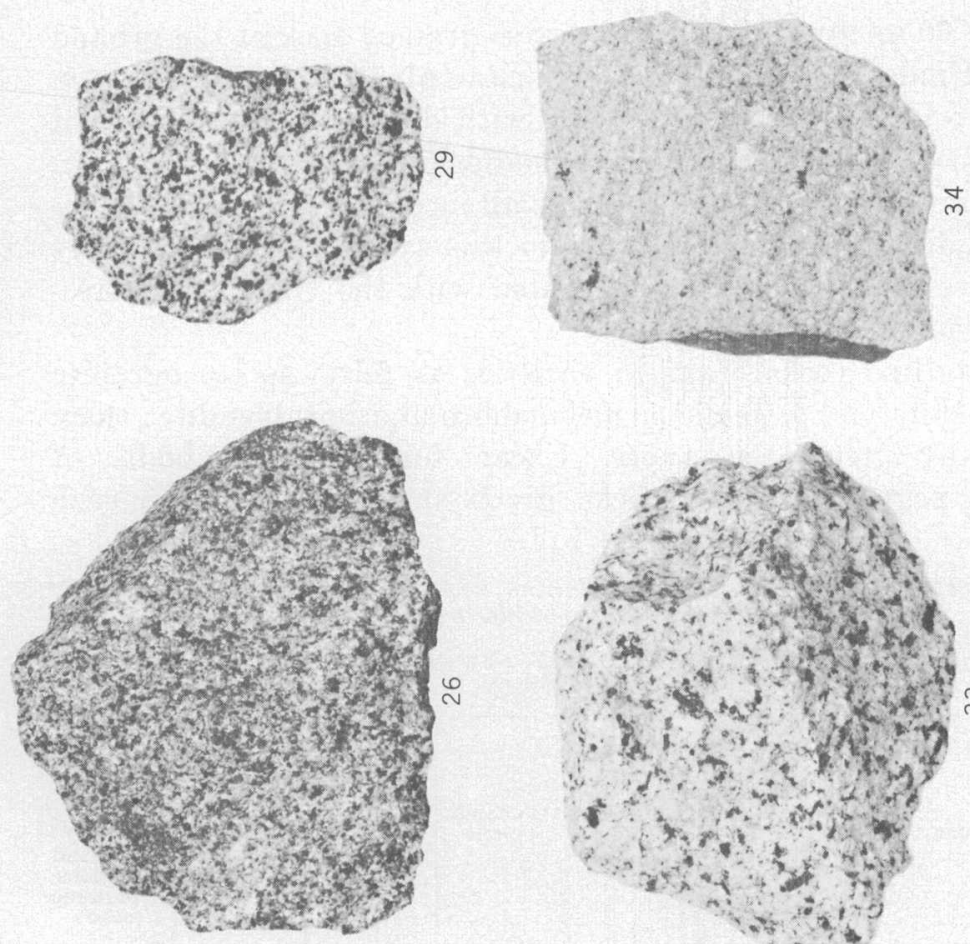

造 $\stackrel{2}{2}$

ले ली है

‥을

ㅇ. 호

嘆

논은

ㅋํㄱ

1 点

$\therefore \infty^{\circ}$

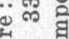

เै...

के 응

렬

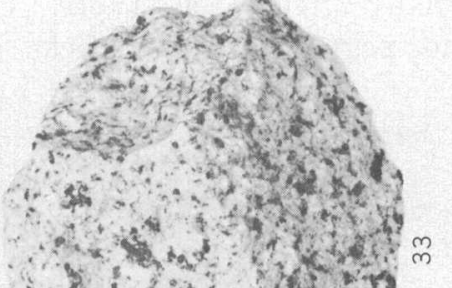

羟

. ఫ

엄

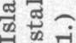

ॠ

密要

$\therefore$ d.

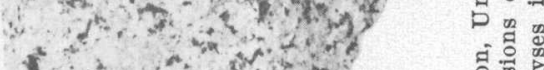

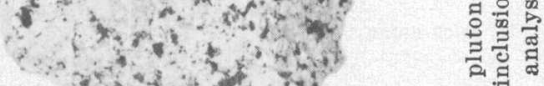

농요

造

a 0

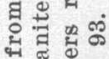

कू

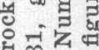
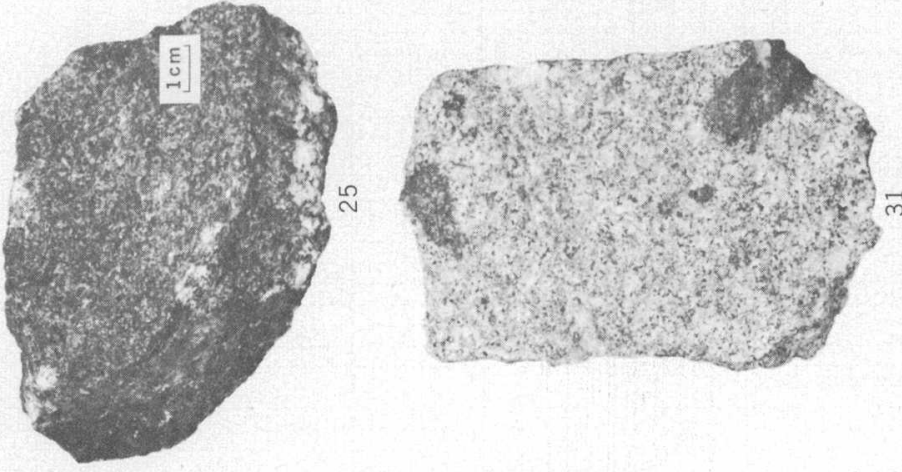

… ㅍ

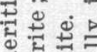

ำ

สี

ฮี ⿷匚⿱

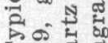

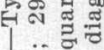

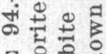

볼 을

品 
other. ${ }^{1} \Lambda$ granodiorite that grades in one direction into a syenodiorite may grade in other directions into quartz monzonite and quartz gabbro, and all three of these rocks may grade into one another. Apparently nearly all chemical constituents act as independent variables. The following descriptions are concerned with the distribution of this multiplicity of igneous rock types within six natural groupings of holocrystalline rocks.

\section{SHALER PLUTON}

The Shaler pluton is exposed in the Shaler Mountains of southern Unalaska Island. The rocks are best exposed above altitude 1,500 feet in the glaciated, mountainous interior (figs. 90, 91), and along fiords (fig. 92). Most of the granodiorite is light colored, equigranular, and medium to coarse grained. White andesine-oligoclase, pink orthoclase, clear quartz, green hornblende, and brown biotite are usually recognizable with a hand lens. A preferred orientation of stubby subhedral or euhedral plagioclase crystals is evident in many thin sections. The contact with the surrounding Unalaska formation is marked by a strong topographic depression for 20 miles, in three segments: From north of the head of Pumicestone Bay eastward to the east side of Usof Bay; from the "thumb" of Three Island Bay northward along a stream valley; and westward from south of Tarasof Point.

The large majority of the rocks studied from the Shaler pluton are granodiorites. Fewer than a third are less silicic: quartz diorite, syenodiorite, diorite, gabbro, quartz gabbro, syenogabbro, or calcic quartz monzonite, in order of observed abundance; gabbroic rocks total only 10 percent. A small number are more silicic or felsic than granodiorite: quartz monzonite, granite, albite granite, or monzonite, in order of abundance (table 2). All of these rocks-those that are less silicic and those that are more silicic than granodiorite-are associated with roof pendants or with portions of the main contact (fig. 90, pl. 78) (Jagger, 1908, p. 19, 32). Locally, swarms of small inclusions of wallrocks are also present, as in the mafic rocks $43 / 4$ miles south-southwest of Tarasof Point, or in the area of small roof pendants northeast of Skan Bay.

\section{BEAVER PLUTON}

The Beaver pluton is exposed on the headlands south of Beaver Inlet. The contact is marked topographically by the east side of

\footnotetext{
${ }^{1}$ In a few outcrops sharp contacts between coarse-grained rocks have been observed. In these places the felsic rocks always dilate the mafic rocks; elsewhere these same rocks are gradational into each other. Sharp internal contacts are an extreme rarity within plutons of Unalaska Island, though sharp external contacts are quite common.
} 
Udamat Bay, and perhaps by the trough line of Beaver Inlet on the north side of the mass. Most of the specimens studied from the Beaver pluton are gabbroic; by comparison, only 10 percent of the Shaler pluton rocks studied are gabbroic. The more mafic nature of the Beaver pluton rocks may be due to assimilation of the more mafic wallrocks surrounding this pluton; or a disproportionate number of specimens were collected from the border zone of the pluton, where mafic rocks are more common.

\section{CAPTAINS PLUTON}

The Captains pluton is exposed at the head of Captains Bay. Of the 7 thin sections studied, 3 are from granodiorite; 2, quartz diorite; 1 , quartz monzonite; and 1 , diorite

\section{APIITES AND PEgMatites}

Thin dikes of aplite and pegmatite, dominantly of leucogranite composition, occur throughout the large plutons and in closely adjacent wallrocks and have sharp contacts. Included with this category are anastomosing masses found only near the borders of the large plutons, which have indistinct contacts against surrounding and included rocks (fig. 95). The small anastomosing masses grade into the larger felsic bodies at the border of the batholiths. Inclusionsrich "plum-pudding" rocks, like that in figure 95, are well developed on the north side of Skan Bay, especially on Kof Point (fig. 92).

\section{SMALI HOLOCRYSTALLINE INTRUSIVE BODIES}

About one-half of the small holocrystalline intrusive bodies have gabbroic affinities and one-half have dioritic affinities (table 2). These bodies include 4 small stocks north of Humpback Bay, 1 small stock north of Staraya Bay, 10 unmapped dikelike apophyses near batholithic contacts, and 11 isolated intrusive masses between Riding Cove and Konets Head (pl. 75). Eight thin sections were made of specimens from the large sill exposed in several isolated masses near Cape Aiak. Elsewhere 1 or 2 thin sections were studied from each small holocrystalline intrusive body. Probably many aphanitic dikes and sills are also related to the batholithic intrusion, but as these cannot be distinguished from the dikes feeding sills in the Unalaska formation they are all discussed together (p. 599-600).

The Cape Aiak gabbro sill has a maximum thickness of about 350 feet, wedges out eastward and westward, and covers at least 30 square miles. At its easternmost exposure, the sheet dips $40^{\circ}$ to the south and perhaps there becomes a dike. The sill locally truncates the bedding of the host rocks and sends small stringers into them. Two probable feeder dikes of this sill appear beneath it northeast of Cape Aiak. 


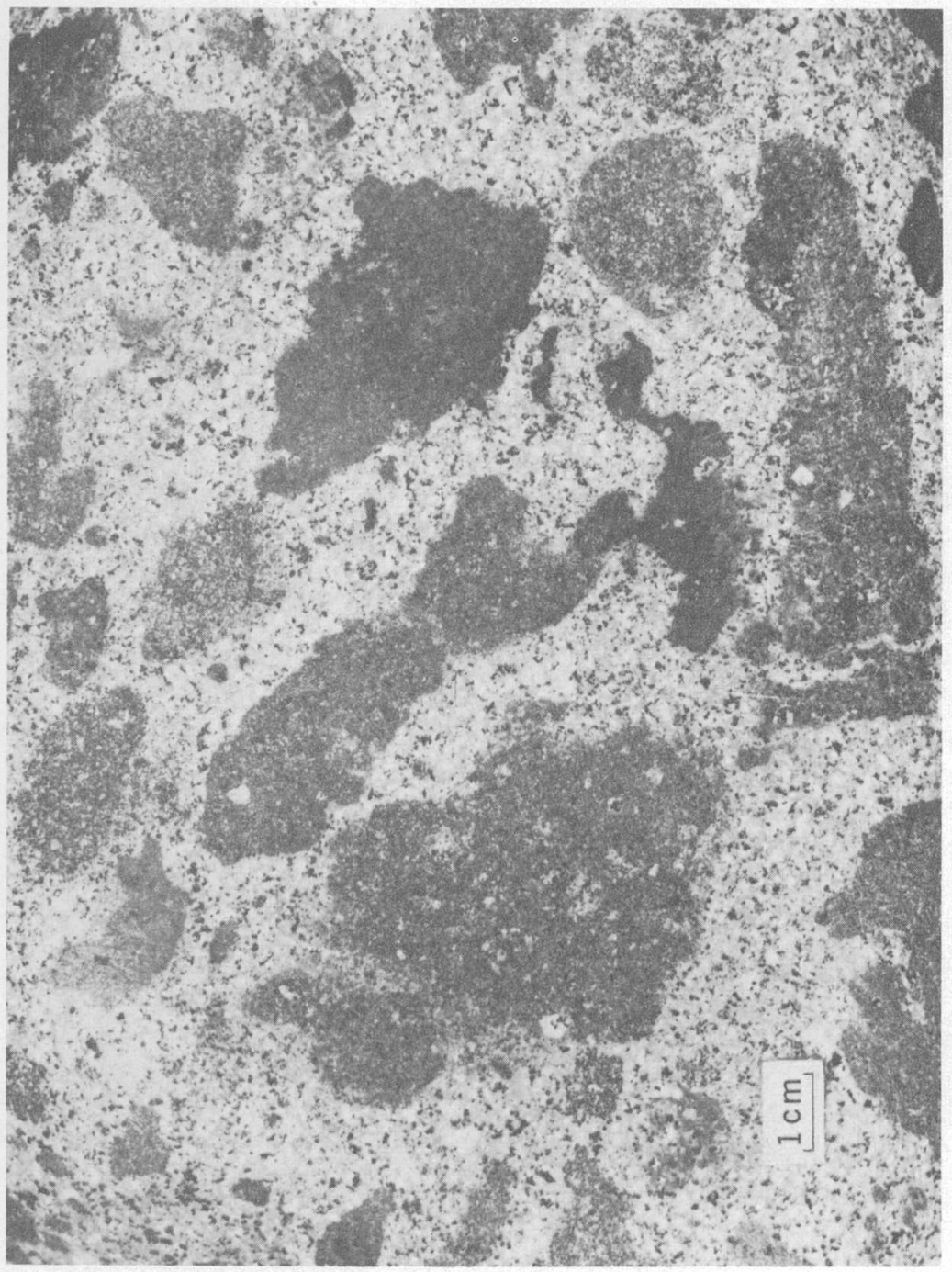

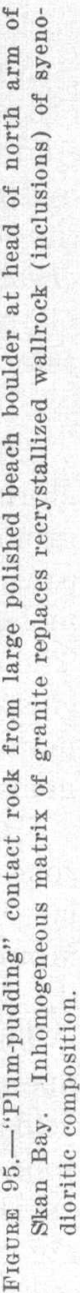


The rocks of the Cape Aiak sill and associated bodies are generally moderately coarse, but fine-grained border phases and less common pegmatitic varieties also occur. Columnar joints are conspicuous in all the sills exposed in coastal or inland cliffs. The unaltered rock is medium to dark gray; where the plagioclase has been albitized the rock is mottled dark gray and very light gray.

A noteworthy diabase sill occurs at Boulder Bay near the southwestern end of the island. The wallrocks there contain 15 to 20 percent of epidote and other secondary minerals. This local and more intense hydrothermally altered area apparently was heated by the magna of the nearby pegmatitic diabase sill. The sill contains numerous phenocrysts of feldspar and pyroxene up to 5 inches long which are intermeshed in such intricate fashion that they must have grown in place after intrusion.

\section{RECRYSTALLIZED WALLROCKS}

The overall composition of the recrystallized wallrocks tends to be more mafic but also more heterogeneous than any other holocrystalline group (table 2). Most representatives would be compositional equivalents of igneous rocks in the range from granodiorite to melagabbro with the volcanic rocks clustered toward granodiorite. The composition of the recrystallized fine-grained sediments tends to cluster around a composition equivalent to melagabbro. Rocks studied under this category include 30 border hornfelses, 6 border schists and gneisses, and 8 inclusions in plutonic rocks.

Holocrystalline wallrocks are limited to a narrow discontinuous zone (exaggerated in fig. 89) around the borders of the batholiths and larger stocks. The best exposures occur in the east half of the 3600 Mountain roof pendant southwest of Naginak Cove (fig. 90) and in the prominent valleys between Raven Bay and Johnson Cove.

The border hornfelsès generally are dark-gray or greenish-gray fine-grained rocks (often mistaken for an igneous chill zone in the field; for a similar account see Cady and others, 1955, p. 87, 88) with sporadic porphyroblasts of biotite, hornblende, or pyroxene. Volcanic structures such as agglomerate fragments, pillows, and bombs are generally obliterated, but the fine bedding characteristic of the sedimentary argillites is commonly preserved, even in small inclusions away from the main contact (fig. 96). The argillites are converted to hornblende-bytownite rocks with alternate layers richer in one or the other of these minerals; long dimensions of crystals are commonly perpendicular to this relict layering.

The foliation of the border schists and gneisses is produced by a preferred mineral orientation and by a parallel arrangement of lenticular rock fragments. These foliated rocks are generally somewhat 


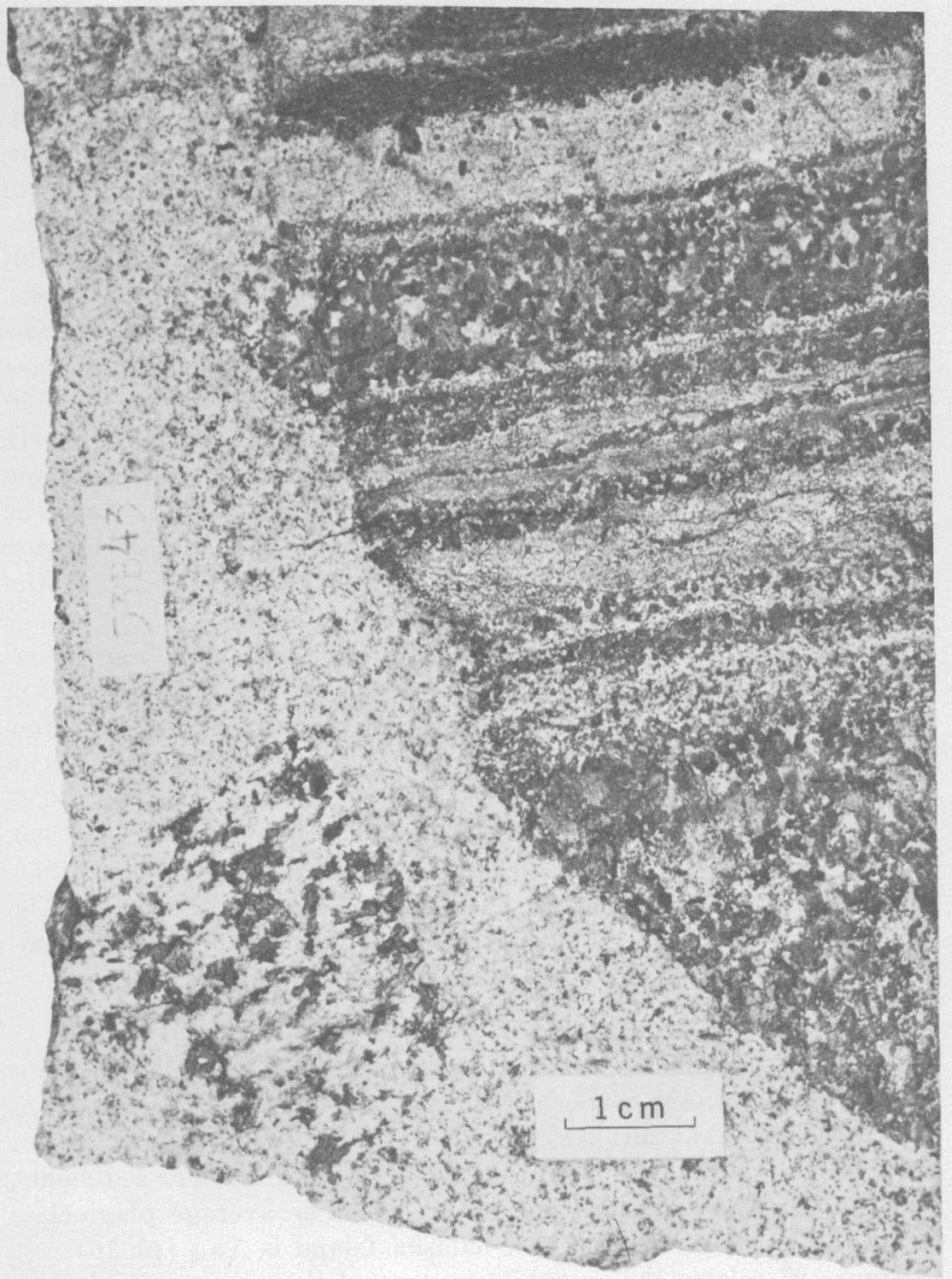

Figure 96.-Recrystallized inclusions of layered argillite in gabbro from small stock on north side of Humpback Bay. Average composition of inclusions is equivalent to that of a melagabbro. Long dimensions of many hornblende and plagioclase crystals in coarse layers are perpendicular to lavering. 
coarser grained than the structureless hornfelses. The hornfelses and gneisses are mineralogically similar. The usual orthopyroxene and clinopyroxene, green or brown amphibole, biotite, plagioclase, quartz, orthoclase, and magnetite are present. Spinel-bearing amphibolite hornfels from Blueberry Bay also contains olivine porphyroblasts. Textures of the holocrystalline border rocks range from schistose to porphyroblastic granulitic ; many porphyroblasts of clinopyroxene, hornblende, or biotite are extremely poikiloblastic. Inclusions near contacts have textures resembling those in nearby wallrocks, whereas inclusions far from contacts have textures resembling those in the surrounding igneous rock. Boundaries of some inclusions are very diffuse. Some shadowy remnants of plagiclose phenocrysts in former lavas are completely replaced by granular aggregates of quartz and alkalic feldspar; in grains where the replacement has not gone to completion and where the surrounding matrix is recrystallized, the matrix plagioclase is 5 to 10 percent more sodic than the phenocryst plagioclase, indicating the amount of disequilibrium between the phenocrysts and groundmass in the original rock.

Border hornfelses are rare in the Aleutians, but have been recognized on Adak Island (Fraser and Snyder, 1959, p. 381, 382, 388); border schists and gneisses are even rarer than hornfelses. A few boulders of coarse gneiss have been found in surficial deposits on Amchitka Island (Powers and others, 1960, p. 542-545; Coats, 1956, pl. 18B), on the shores of Kanaga Island (Fraser and Barnett, 1959, p. 231), and on western Tanaga and Ogliuga Islands (Coats, 1956, p. 88, 89), but the sources of these boulders are not known. The exposures on Unalaska Island are the only known outcrops of dynamically metamorphosed rocks in the Aleutian Islands.

\section{COMPARATIVE MINERALOGY}

The compositions of the average plagioclase of the holocrystalline rocks ${ }^{2}$ are $\mathrm{An}_{39}$ in the Shaler pluton; $\mathrm{An}_{57}$ in the Beaver pluton; $\mathbf{A n}_{44}$ in the Captains pluton; $\mathrm{An}_{24}$ in the aplites cutting plutonic rocks; $A n_{51}$ in the small intrusive masses cutting volcanics and sediments, and $\mathrm{An}_{47}$ in the recrystallized wallrocks. The average plagioclase for all holocrystalline rocks of Unalaska Island is $\mathrm{An}_{42}$ (pl. 76).

Figure 97 relates the anorthite content of the average plagioclase and the total percent of mafic minerals for four groups of holocrystalline rocks on Unalaska Island and illustrates the intermediate compositional position of the plutonic border rocks and apophyses between the relatively uncontaminated central plutonic rocks and the mafic wallrocks.

\footnotetext{
${ }^{2}$ Determined by taking the arithmetic mean of the anorthite content of 6 to 40 individual plagioclase crystals per specimen, and then taking the arithmetic mean of all the average anorthite contents for each specimen within a particular group.
} 


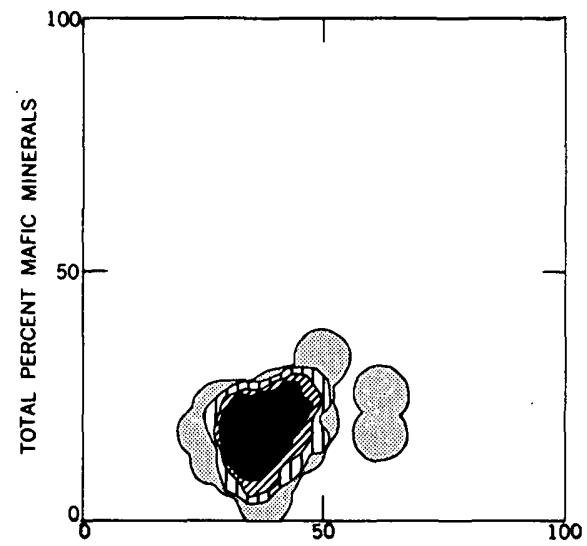

PERCENT An IN AVERAGE PLAGIOCLASE

$A$-Plutonic rocks (Shaler, Beaver, and Captains plutons) greater than one. half mile from a mapped contact: 45 specimens

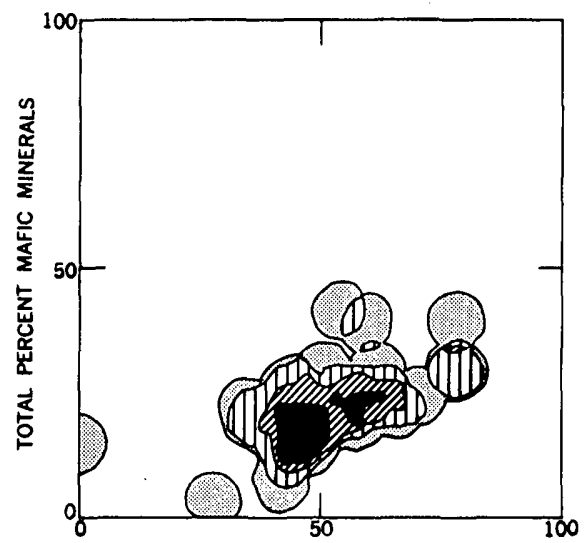

PERCENT An IN AVERAGE PLAGIOCLASE

C.-Small intrusive bodies (Stocks, sills, apophyses): 30 specimens

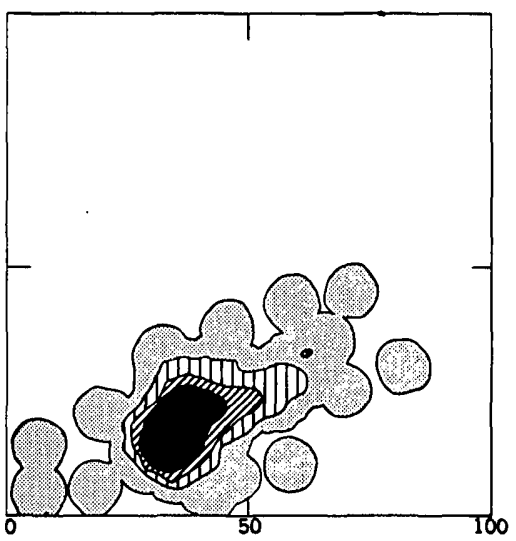

PERCENT An IN AVERAGE PLAGIOCLASE

B.-Plutonic rocks (Shaler, Beaver, and Captains plutons) less than one-half mile from a mapped contact: 115 specimens

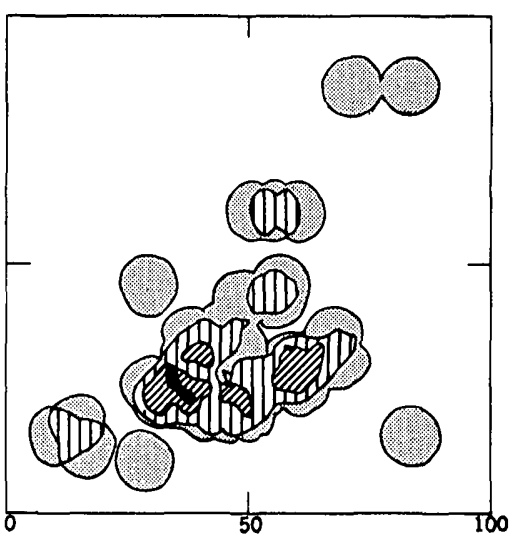

PERCENT An IN AVERAGE PLAGIOCLASE

$D$-Recrystallized wallrocks (contact hornfels and schist and inclusions in plutonic rocks): 36 specimens

\section{EXPLANATION}

Contours showing percentage of specimens per 1-percent area of graph
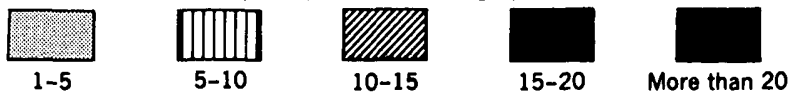

Figuk: 97.-Graph showing distribution of total mafic mineral content and anorthite content of average plagioclase for holocrystalline rocks of Unalaska Island; illustrates increasing mafic content, increasing calcic content, and decreasing homogeneity in the series $A, B, C, D$. 


\section{SPECIFIC DATA FOR ANALYZED ROCKS}

Chemical analyses of 13 specimens of plutonic rocks of Unalaska Island and 10 wallrocks of the Unalaska formation, which are reported in table 1 and plotted on figure 88, support the indirect conclusions about the compositions derived from the mineralogical data. Some of the analyses are of rocks of rare occurrence and are included to illustrate the range of composition of the suite. Both plutonic rocks and wallrocks have representatives throughout the range of chemical composition. Practically all the specimens analyzed are magmatic types, and the fine-grained sediments of the Unalaska formation are not represented.

Analysis 17 is of a composite sample of 32 small hand specimens of the Unalaska formation from the Skan Bay-Naginak Cove area. In this sample, lava makes up 51 percent of the weight, tuff 34 percent, and clastic sediments the remaining 15 percent; these proportions are crudely representative of the formation in that area near the north margin of the Shaler pluton. Specimen 33 is most nearly representative of the north part of the pluton and is less femic in all respects than specimen 17 .

The estimated modes agree reasonably well with the appropriate normative minerals. The difference between normative and modal quartz is 3 percent or less for all but two of the analyzed rocks. The difference between normative and modal orthoclase is 5 percent or less for all but four of the analyzed rocks. The anorthite composition of the normative plagioclase and the average modal plagioclase agree within 5 percent for all but three analyzed rocks. The normative nepheline in analysis 2 and the normative corundum in analysis 34 have no observed counterparts in thin section. Specific agreements and discrepancies will be discussed under the detailed descriptions which follow.

Specimen 2 is a gabbro from the sea cliff 3 miles north-northeast of the southern tip of Cape Aiak. The texture is porphyritic and hypidiomorphic, and the mafic minerals are locally aggregated. Felsic minerals range in abundance from 50 to 70 percent, of which about 1 percent is orthoclase and the rest is plagioclase replaced by $\mathbf{1 0 - 1 5}$ percent albite and. minor sericite. The unaltered plagioclase composition, by extinction angle, is $\mathrm{An}_{78}$ [mean of 26 crystals, standard deviation is 11 percent An, average amount of zoning per individual plagioclase crystal is 3 percent An per crystal (fig. 93, no. 12)] ; by index oils, is $\mathbf{A n}_{08}$. Mafic minerals make up 30-50 percent, of which $25-30$ percent is stubby euhedral phenocrysts of clinopyroxene, 2-3 percent clinopyroxene or uralite needles (length-to-width ratio is $20: 1$ ) grown on the margins of the large pyroxenes rather than altered from them, $0-1$ percent biotite(?) now completely altered to antigorite, $8-10$ percent magnetite, $<1$ percent is apatite, and $<1$ percent serpentine.

Discrepancy in plagioclase compositions (above) is probably due to two causes. (1) Low temperature curves were used; using the same angles, high 
temperature curves give average plagioclase as $\mathrm{An}_{\mathrm{67}}$ (2) Alteration to albite lowers normative plagioclase. Presence of 7.10 percent olivine and 0.85 percent nepheline in the norm is unexplained, but other specimens from the Cape Aiak sill contain abundant zeolites through out the the groundmass, and if the analyzed sample contained a pocket of these the total rock might be undersaturated in silica.

Specimen 13 is a recrystallized wallrock, equivalent to syenodiorite in composition, from a beach boulder at the southeast end of the north arm of Skan Bay: it occurs as an inclusion in granite like that represented by analysis 32. The texture is hypidiomorphic-granular. Felsic minerals compose $75-80$ percent of the rock: $2-3$ percent quartz, 5-10 percent orthoclase partially altered to kaolin (1-2 percent), and 65-70 percent plagioclase partially altered to sericite (2-3 percent) and clinozoisite ( 0.1 percent). The plagioclase composition, by extinction angle, is $\mathrm{An}_{35}$ (mean of 10 crystals, standard deviation is 6 percent $A n$, a verage amount of zoning per individual plagioclase crystal is 11 percent An per erystal). Mafic minerals compose 20-25 percent: 10-14 percent hornblende (much is interstitial), 5-10 percent biotite partially altered to epidote (0.1-0.5 percent) and penninite (0.1-1 percent), 1-3 percent magnetite, 0.1-1 percent spheve (associated with the magnetite) partially altered to leucoxene $(0.1-0.5$ percent), one large grain of tourmaline (about 0.3 percent), and $<0.01$ percent hematite.

Specimen 25 is a quartz gabbro from elevation 1,000 feet on the west-facing hill slope $23 / 4$ miles southwest of Tarasof Point. The texture is hypidiomorphicgranular. Felsic minerals compose 75-80 percent of the rock: 4-6 percent quartz, $<0.1^{\circ}$ percent orthoclase, and $70-75$ percent plagioclase slightly altered to sericite $(<0.1$ percent). The plagioclase composition, by extinction angle, is $\mathrm{An}_{64}$ [mean of 36 crystals, standard deviation is 7 percent $A n$, average amount of zoning per individual plagioclase crystal is 9 percent An per crystal (fig. 93, no. 10) ]. Mafic minerals compose $20-25$ percent : $0.5-1.5$ percent clinopyroxene (remnants in hornblende and euhedra in feldspar), 8-10 percent hornblende (an indeterminate amount derived from clinopyroxene), 6-8 percent biotite slightly altered to penninite $(<0.1$ percent) and cliozoisite $(<0.1$ percent), 2-5 percent magnetite, $<0.1$ percent hematite, $0.5-1.5$ percent apatite, 0.5-1 percent tourmaline, and $0.1-1$ percent penninite (interstitial).

Potassium oxide apparently is contained in biotite, sericite, and plagioclase. Thin sections stained for $\kappa_{2} \mathrm{O}$ failed to reveal any more than the amount of orthoclase shown.

Specimen 26 is a granodiorite from the rock bench at the tip of the headland south of the largest stream on the north side of Skan Bay. The texture is hypidiomorphic-granular. The rock contains $70-75$ percent felsic minerals: 7-10 percent quartz, 15-18 percent orthoclase partially altered to kaolin (1-3 percent), and $\mathbf{4 5 - 5 0}$ percent plagioclase preferentially altered in centers to sericite (3-5 percent). The plagioclase composition, by extinction angle, is $\mathbf{A n}_{40}$ [mean of 35 crystals, standard deviation is 9 percent An, average amount of zoning per individual plagioclase crystal is 0 percent An per crystal (fig. 93. no. 5) ] ; by index oils, is $\mathrm{An}_{30}$. Mafic minerals make up 25-30 percent; 5-10 percent clinopyroxene slightly altered to hornblende $(0.3-0.5$ percent), 3.7 percent hornblende partially altered to antigorite (1-2 percent) and minor magnetite, 10-15 percent biotite slightly altered to penninite $(<0.01$ percent), $2-3$ percent magnetite, $<1$ percent sphene slightly altered to leucoxene $(<0.01$ percent $)$, and $0.5-1.5$ percent apatite.

Specimen 27 is a granogabbro occurring one-third mile from the Beaver pluton contact on the east side of Final Bay. The texture is hypidiomorphic and the 
groundmass is myrmekitic. Felsic minerals compose $80-85$ percent of the rock: 7-10 percent quartz, $15-25$ percent alkali feldspar partially altered to kaolin (2-3 percent), and 50-58 percent plagioclase partly altered to sericite (about 5 percent) and epidote-clinozoisite (about 1 percent). The plagioclase composition, by extinction angle, is $\mathrm{An}_{62}$ [mean of 28 crystals, standard deviation is 10 percent An, average amount of zoning per individual plagioclase crystal is 2 percent $A$ n per crystal ], by index oils, is $A_{54}$. Mafic minerals compose $15-20$ percent: 10-13 percent uralitic hornblende (probably 85 percent of this after pyroxene, 15 percent after biotite) partly altered to penninite $(0.5-1.5$ percent $)$. $0.5-1.5$ percent sphene partly altered to leucoxene (0.1 percent), 4-6 percent magnetite, and $<1$ percent apatite.

The discrepancy in plagioclase composition is probably due to sodium in the alkalic feldspar, and potassium in the plagioclase(?).

Specimen 28 is a granodiorite from the Shaler pluton near the contact on the ridge between Blueberry Bay and Three Island Bay. The texture is hypidiomorphic-granular. Felsic minerals compose 70-80 percent of the rock: 10-15 percent quartz with undulatory extinction, 5-10 percent orthoclase partly altered to kaolin ( $<1$ percent), and 50-60 percent plagioclase partly altered to sericite ( $<5$ percent). The plagioclase composition, by extinction angle, is $\mathrm{An}_{43}$ [mean of 22 crystals, standard deviation is 12 percent An, average amount of zoning per individual plagioclase crystal is 4 percent An per crystal]; by index oils, is $\mathrm{An}_{46}$. Mafic minerals compose 20-30 percent : $<1$ percent clinopyroxene (remnants), 9-14 percent hornblende (an indeterminate amount after pyroxene) partially altered to magnetite $(<1$ percent) and hematite $(<1$ percent), 9-14 percent biotite partly altered to penninite $(2-3$ percent) and sphene $(0.1-0.5$ percent), 0.5-1.5 percent of apatite, $0.5-1.5$ percent magnetite-ilmenite, $<1$ percent sphene, $<0.01$ percent zircon (two small crystals, one with a pleochroic halo in biotite, the other with a pleochroic halo in hornblende). The rock is cut by a thin vein of orthoclase.

Specimen 29 is a granodiorite from 1 mile northeast of the head of Raven Bay. The texture is hypidiomorphic-granular. Felsic minerals compose $\mathbf{7 5}-80$ percent of the rock : 10-15 percent quartz, 10-15 percent orthoclase partly altered to kaolin ( $<1$ percent), and 50-55 percent plagioclase partly altered to sericite ( $<1$ percent). The plagioclase composition, by extinction angle, is $\mathbf{A n}_{34}$ [mean of 21 crystals, standard deviation is 3 percent An, average amount of zoning per individual plagioclase crystal is 3 percent An per crystal (fig. 93, no. 3) ], by index oils, is $A n_{38}$. Mafic minerals compose 20-25 percent : 4-6 percent clinopyroxene partly altered to hematite $(<0.01$ percent) and hornblende $(3-4$ percent, occurs as reaction zones between pyroxene and biotite; pyroxene adjacent to feldspar and quartz is not altered to hornblende), 13-17 percent biotite slightly altered to hematite ( $<0.01$ percent), 1-3 percent magnetite-ilmenite, $<1$ percent sphene (this includes $<0.1$ percent sphene which occurs as reaction rims around some magnetite-ilmenite in biotite), and 0.5-1.5 percent apatite. Parallel oriented euhedral inclusions of pyroxene, biotite, magnetite, and apatite occur in some of the larger plagioclase crystals.

Specimen 30 is a granodiorite from the Captains pluton 1 mile southwest of the head of Captains Bay. The texture is hypidiomorphic-granular to porphyritic. Felsic minerals compose 75-85 percent of the rock: 10-15 percent quartz, 13-17 percent orthoclase partly altered to kaolin (2-4 percent), and 50-55 percent plagioclase partially altered to sericite (0.5-1.5 percent) and clinozoisite $(<0.01$ percent). The plagioclase composition, by extinction angle, is $A n_{48}$ [mean of 24 crystals, standard deviation is 14 percent $A n$, aver- 
age amount of zoning per individual plagioclase crystal is 16 percent An per crystal (fig. 93, no. 8) ], by index oils, is $\mathrm{An}_{44}$. Mafic minerals compose 15-25 percent: 1 percent pyroxene (all as small inclusions in one large plagioclase crystal), 12-15 percent hornblende ( 50 percent of this is massive and poikilitic with magnetite, 50 percent of this is uralitic fibers), 3-5 percent biotite partially altered to penninite (1-2 percent) and ilmenite and sphene $(0.5-1.5$ percent) which in turn are altered to leucoxene $(<1$ percent $), 2.4$ percent magnetite, and $<1$ percent apatite (in feldspar).

Specimen 31 is a granite, the matrix of a "plum pudding" rock like that of figure 95, from the shore bench one-half mile southeast of the tip of Kof Point (near fig. 92). The texture is hypidiomorphic, micrographic; the original rock contains many inclusions but this analysis is of the matrix only. Felsic minerals compose 75-80 percent of the rock: 5-7 percent quartz occurring in myrmekitic to micrographic intergrowths with much alkalic feldspar, 45-55 percent alkalic feldspar partly altered to kaolin (3- 7 percent), and 15-25 percent plagioclase partly altered to sericite (2-4 percent), kaolin (2-5 percent), albite (lumped with alkalic feldspar) and epidote (1-2 percent). The plagioclase composition, by extinction angle, is $\mathrm{An}_{41}$ [mean of 10 crystals, standard deviation is 16 percent An, average amount of zoning per individual plagioclase crystal is 13 percent $A n$ per crystal], by index oils, is $A n_{37}$. Mafic minerals compose 20-25 percent: 12-15 percent clinopyroxene mostly replaced by actiuolitic hornblende $(10-13$ percent), sphene $(<1$ percent), and magnetite ( $<1$ percent), 5-7 percent biotite completely replaced in most areas by epidote $(<1$ percent), penninite $(3-4$ percent $)$, titanite $(0.5-1.5$ percent) and magnetite-ilmenite (0.5-1.5 percent), $2-4$ percent magnetiteilmenite, $<1$ percent apatite, $<0.1$ percent epidote, sphene, penninite, and a fibrous amphibole that fills tiny holes in the groundmass.

The discrepancy in the plagioclase composition between the mode and the norm is probably due to the presence of secondary albite in the rock. Also, the alkalic feldspar probably contains large quantities of both orthoclase and albite molecules.

Specimen 32 is a granite, the matrix of a "plum pudding" rock like that of figure 95, from a beach boulder near the head of the north arm of Skan Bay. The texture is hypidiomorphic-granular; the original rock contains many inclusions of the type represented by analysis 13 but this analysis is of matrix only. Felsic minerals compose $93-97$ percent of the rock : 10-20 percent quartz, 50-70 percent alkalic feldspar heavily altered to kaolin (10-20 percent), and 15-25 percent plagioclase partly altered to epidote $(0.1-0.5$ percent), sericite (0.1-1 percent), and kaolin (lumped with above). The plagioclase composition, by extinction angle, is $\mathrm{An}_{18}$ [mean of 5 crystals, standard deviation is 9 percent An, average amount of zoning per individual plagioclase crystal is 0 percent An per crystal]. Mafic minerals compose 3-7 percent: 2-3 percent hornblende and $0.1-0.5$ percent is biotite both partly altered to epidote $(0.1-1$ percent) and penninite (0.1-0.3 percent), 1-1.5 percent is magnetite, 0.1-1 percent is sphene slightly altered to lucoxene, $0.1-0.5$ percent is rutile occurring as stubby yellow rods in sphene, and $0.1-0.3$ percent is penninite (interstitial).

Comparison of the mode and norm for this rock indicates that the alkalic feldspar contains large quantities of both orthoclase and albite.

Specimen 33 is a granodiorite from north of the 3600 Mountain roof pendant, midway between Skan Bay and Naginak Cove. The texture is hypidiomorphicgranular. Felsic minerals compose $80-85$ percent of the rock: 15-20 percent quartz, 10-15 percent orthoclase slightly altered to kaolin $(<1$ percent), and 
50-55 percent plagioclase partially altered to sericite (1-2 percent). The plagioclase composition, by extinction angle, is $\mathrm{An}_{38}$ [mean of 40 crystals, standard deviation is 13 percent An, average amount of zoning per individual plagiclase crystal is 8 percent An per crystal (fig. 93, no. 4) ], by index oils, is $A n_{40}$. Mafic minerals compose $15-20$ percent: $5-8$ percent actinolitic hornblende as long as $10 \mathrm{~mm}, 8-12$ percent biotite up to $7 \mathrm{~mm}$ in diameter and partially altered to penninite (1-2 percent) and sphene $(<1$ percent, itself slightly altered to leucoxene $<0.01$ percent), $1-2$ percent magnetite, and $<0.01$ percent apatite (in plagioclase).

.Specimen 34 is a leuco albite quartz monzonite from an irregular aplitic body at the margin of the 3600 Mountain roof pendant, 0.7 mile southwest from the summit of the 3,600-foot peak for which the pendant is named. The texture is allotriomorphic-granular, locally subgraphic, locally pseudoperthitic. The specimen contains 94-98 percent felsic minerals: 20-24 percent quartz, 25-34 percent orthoclase slightly altered to kaolin, and 40-49 percent plagioclase (only one-sixth of which is twinned) slightly altered to sericite. The plagioclase composition, by extinction angle, is $\mathrm{An}_{7}$ [mean of 12 crystals, standard deviation is 3 percent An, average amount of zoning per individual plagioclase crystal is 0 percent An per crystal (fig. 93, no. 1) ]. There are $2-6$ percent mafic minerals of which $2-6$ percent is biotite (?) completely altered to magnetite $(0.5-1.5$ percent), penninite $(2-3$ percent), epidote $(<0.1$ percent), and sphene $(0.1-1$ percent), and $<0.3$ percent is allanite associated with minor epidote.

The discrepancy in the amounts of normative and modal quartz may be due to unrecognized fine-grained quartz in the groundmass, or perhaps some of the quartz was mistakenly identified with the abundant untwinned plagioclase.

Specimen 35 is a granodiorite from near the head of Captains Bay. No hand specimen or thin section is available.

\section{ALTERATION}

Almost none of the plutonic rocks studied in thin section contain more than 10 percent of mineral alteration products (fig. 89). The hornfelses, schists, and gneisses are completely recrystallized but contain virtually no later alteration; they are only rocks of the Unalaska formation that are completely recrystallized.

Alteration minerals in the plutonic rocks include: sericite (from alteration of plagioclase feldspar, often associated with late orthoclase feldspar, usually present in amounts of 0.5-3 percent); kaolin (from alteration of potassic and occasionally plagioclase feldspar, amount difficult to estimate but usually less than 5 percent) ; epidoteclinozoisite (epidote is commonly an alteration product of biotite, and clinozoisite of plagioclase, in few places present in amounts greater than 1 percent) ; tremolite-actinolite (common after hornblende, rare after plagioclase); zeolites (includes analcite, thomsonite, and stilbite, present to 10 percent in some of the western Unalaska sills); prehnite (associated with zeolites, rare); calcite (present in only one-tenth of the rocks as alteration of either felsic or mafic minerals, generally 1-2 percent where present, a few concentrations greater than 10 percent known); sphene (commonly present as small parallel blebs or 
groups of blebs reflecting former biotite cleavage, usually less than 1 percent); leucoxene (nearly all specimens present as very minor amounts on sphene or ilmenite); hematite (pseudomorphous after pyrite or as small flakes in mafic minerals, nearly always less than 0.5 percent) ; serpentine (alteration of olivine (?) in sills of western Unalaska, present to 5-10 percent in some of these rocks, absent elsewhere) ; vermiculite (present as alteration of biotite in one pegmatite) ; magnetite (rare as alteration product) ; limonite (rare); rutile (occurs as stubby yellow rods in alterated (?) sphene, rare); and chlorite (includes bastite after orthopyroxene, fine-grained antigorite after hornblende and some biotite, and penninite after biotite and some hornblende; bastite rare, antigorite uncommon, penninite commonly present in amounts of $1-4$ percent). There is a suggestion that the penninitic chlorite possesses different optical properties (abnormal interference colors) in different parts of the Shaler pluton in the Skan Bay-Naginak Cove area.

Of the plutonic rocks studied in thin section, 22 percent contain dilation veins, though many veins are too thin to be seen in hand specimen. Most of these rocks ( 86 percent) were collected within 0.5 mile of a known plutonic contact, more than one-half were collected within 0.1 mile of a known contact. Chlorite and orthoclase are the commonest fillings; all other major primary and secondary minerals except olivine, calcic plagioclase, biotite, orthopyroxene, zircon, and apatite are also represented.

PLUTONIC ROCKS: SUMMARY AND INTERPRETATION

The plutonic rocks of Unalaska Island are the products of crystallization of a granodioritic magma that invaded the rocks of the Unalaska formation by assimilation, stoping, and forceful intrusion, and possibly by melting. During late crystallization of at least one of the batholiths the core became enriched in alkalies, silica, and rare earths. I ate solutions developed a uniform kaolin-chlorite-sericite alteration throughout the plutons.

The typical plutonic rock is equigranular granodiorite with hypidiomorphic texture. Practically all changes in composition of plutonic rocks are gradational. The most mafic though compositionally variable igneous rocks are in the small intrusive bodies or are near the borders, especially the roof zones of the large intrusive bodies, and the wallrocks are still more mafic and inhomogeneous. Locally, near the borders of the largest plutons, porphyroblastic hornfelses and schists have been formed from wallrocks. In at least the Shaler pluton, broad composition zones (ignoring areas of roof rocks) are concentric with the outer walls of the pluton and are increasingly felsic toward the center (fig. 98). 


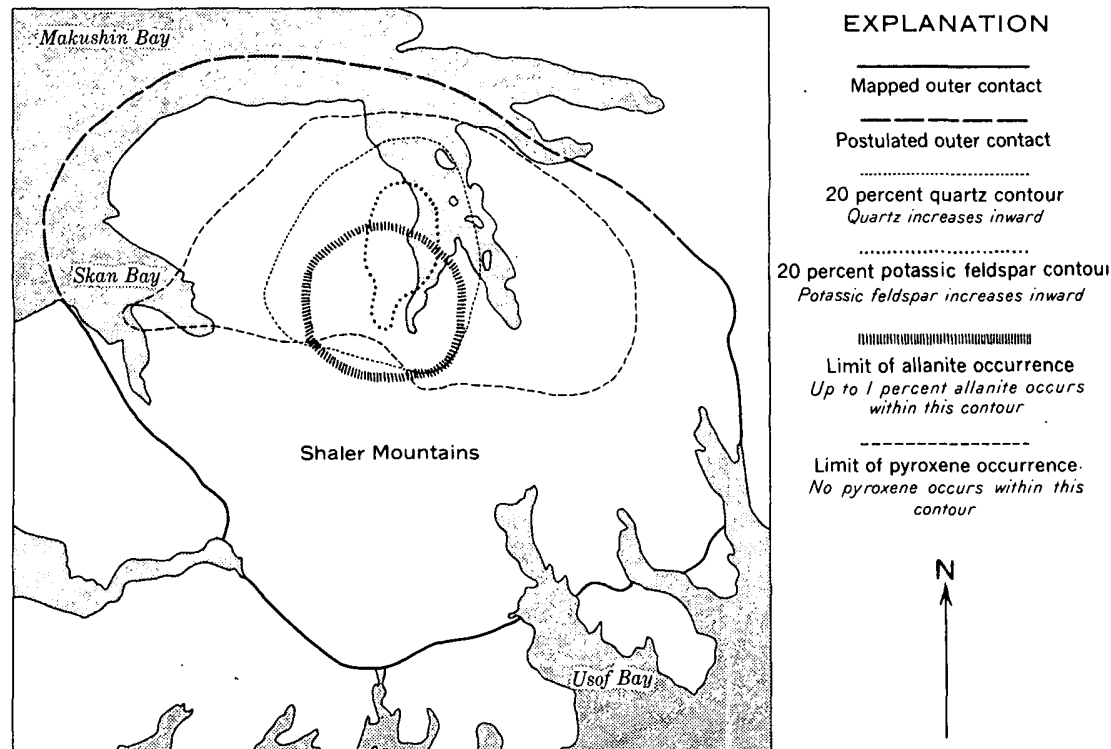

FigURE 98.-Concentric mineral zones within Shaler pluton, with roof rocks and plutonic border phases removed.

The increase in both mafic content and inhomogeneity from batholith center to and including wallrocks indicates that the magma bodies have been modified in composition near their borders, especially their roofs, by a wallrock complex of heterogeneous volcanic rocks and basic sediments. Because of these compositional characteristics, some form of assimilation in place or melting of wallrock must be the requisite explanation. Similar conclusions have recently been drawn for other Aleutian areas (Fraser and Snyder, 1959, p. 389) and for the much larger California batholiths (Hamilton, 1956a, p. 1596-1597; 1956b, p. 1795 ; McCulloh, 1954, p. 21).

A possible mechanism of emplacement for the Unalaska batholiths is suggested: Melting of the Unalaska formation or older formations begins and proceeds irregularly outward until a large molten mass has been formed within the crust of the earth. Motion caused by tectonic stresses or convection currents produces dynamically metamorphosed wallrock in a few places, results in small apophyses of basic border rocks intruding upward into the Unalaska formation, and orients stubby plagioclase crystals. Locally the more basic, more viscous border phases of the pluton are displaced by the more homo- 
geneous, less viscous central phases of granodiorite magma and very locally sharp internal contacts are produced. The final position of the batholith may be slightly above the position where it was originally formed or may be very far above this position, depending upon the quantity and duration of the available supply of heat and upon the relative efficacy of the stoping, fluxing, and forceful intrusive mechanisms. As the heat supply dwindles, crystallization begins at the outer walls and proceeds irregularly inward until the mass is completely solidified, a process possibly lasting more than a million years (Lovering, 1955, p. 271, 277). If upward migration of the molten magma bodies was significant, it is possible that the many finegrained sills and lava flows in the Unalaska formation were derived from this rising series of batholiths. Later in their history the plutons would have engulfed and altered their own earlier extrusive products.

Other causes of diverse plutonic compositional suites are not applicable here. Successive intrusion of different plutons of decreasing basicity is ruled out, first by the extreme coincidence required to explain the compositional progression into the wallrock, and second by the gradational nature of the great majority of the contacts between'the different igneous rock types. Separation of immiscible fractions from a single parent magma body is refuted for the same reasons. The Unalaska situation is the reverse of that normally prescribed for crystal differentiation. The basic border rocks are largely at the roof of the pluton, opposite to what would be expected if gravitative settling had played a large part in their disposition. Filter pressing of a partly crystalline mass does not satisfactorily explain the inhomogeneity of the border areas.

The late history of the Shaler pluton is partly revealed by the concentric mineral zones within it beneath the roof areas (fig. 98). All four of these zones can be shown texturally to have developed late in the history of the rock. The limit of pyroxene occurrence represents the point at which all the pyroxene has been converted to amphibole or where amphibole has crystallized instead of pyroxeneevents late in the reaction series. Quartz, potassic feldspar, and allanite show by their typical shapes in thin section (p. 615-616) that they formed last in the history of the rock and their concentration in the central area suggests that this area was subjected longest to crystallization processes. All of these mineral zones may be the result of late crystallization of uncontaminated central portions of the magma, but at least part of them probably were formed from hydrothermal solutions which utilized the core of the crystallizing magma column as a flue until it was completely solid. If so, the original magma may have been a granodiorite lower in quartz and potassic feldspar 
than the rock exposed in this central zone. Late solutions rich in alkalies and silica probably congregated at many local points beneath the roof to give rise to the contact "plum pudding" rocks and many irregular aplites. A similar interpretation has previously been advocated for the Adak batholith (Fraser and Snyder, 1959, p. 389,390$)$. During this late hydrothermal period a uniform kaolinchlorite-sericite alteration was developed throughout the plutons, and small joints in the more brittle rocks near the contacts were filled with all the late minerals. The hornfels zone, with its complete lack of hydrothermal alteration, apparently was impervious to, or too distant from, the late alteration solutions. Indirectly, this lack of alteration in the hornfels zone points to the regional alteration of the Unalaska formation as a prebatholith phenomenon or a phenomenon related to the early stage of batholith emplacement.

\section{MAKUSHIN VOLCANICS}

A thick pile of unaltered and little-deformed lava and pyroclastic rocks overlies the Unalaska formation and granodiorite plutons with slight angular unconformity and forms Makushin Volcano, a broad volcanic dome more than 6,000 feet high and 10 miles wide (figs. 99 and 100).

These rocks, which consist of basalt and subordinate andesite, are here designated the Makushin volcanics; they are now restricted to the northern part of the northern bulge of the island, though they probably once extended farther south. Locally they are unconformably capped by basaltic flows and pyroclastic rocks that retain their constructional forms. The thickness of the Makushin volcanics is highly varied but probably does not exceed several thousand feet. The formation is of Pliocene(?) and Pleistocene age. The bulk of the rocks is probably late Pleistocene. The rocks of the formation are typically exposed in the sea cliffs and ridges near Reese Bay.

\section{UNCONFORMITY BENEATH THE MAKUSHIN VOLCANICS}

The lower surface of the volcanic pile is irregular, with marked local relief in many places, and a general northward slope so that the pile caps ridges on the south and reaches below sea level on the north. The basal unconformity is marked by structural discordance, by the upward limit of strong alteration, by the truncation of many dikes, and by a discontinuous basal conglomerate locally containing cobbles of granodiorite and rocks of the Unalaska formation. A deep zone of intense oxidation and clay formation in the older rocks is particularly prominent on ridges adjacent to Glacier Valley and in places beneath the Makushin volcanics, and resembles the remnants of an exhumed weathered surface. 


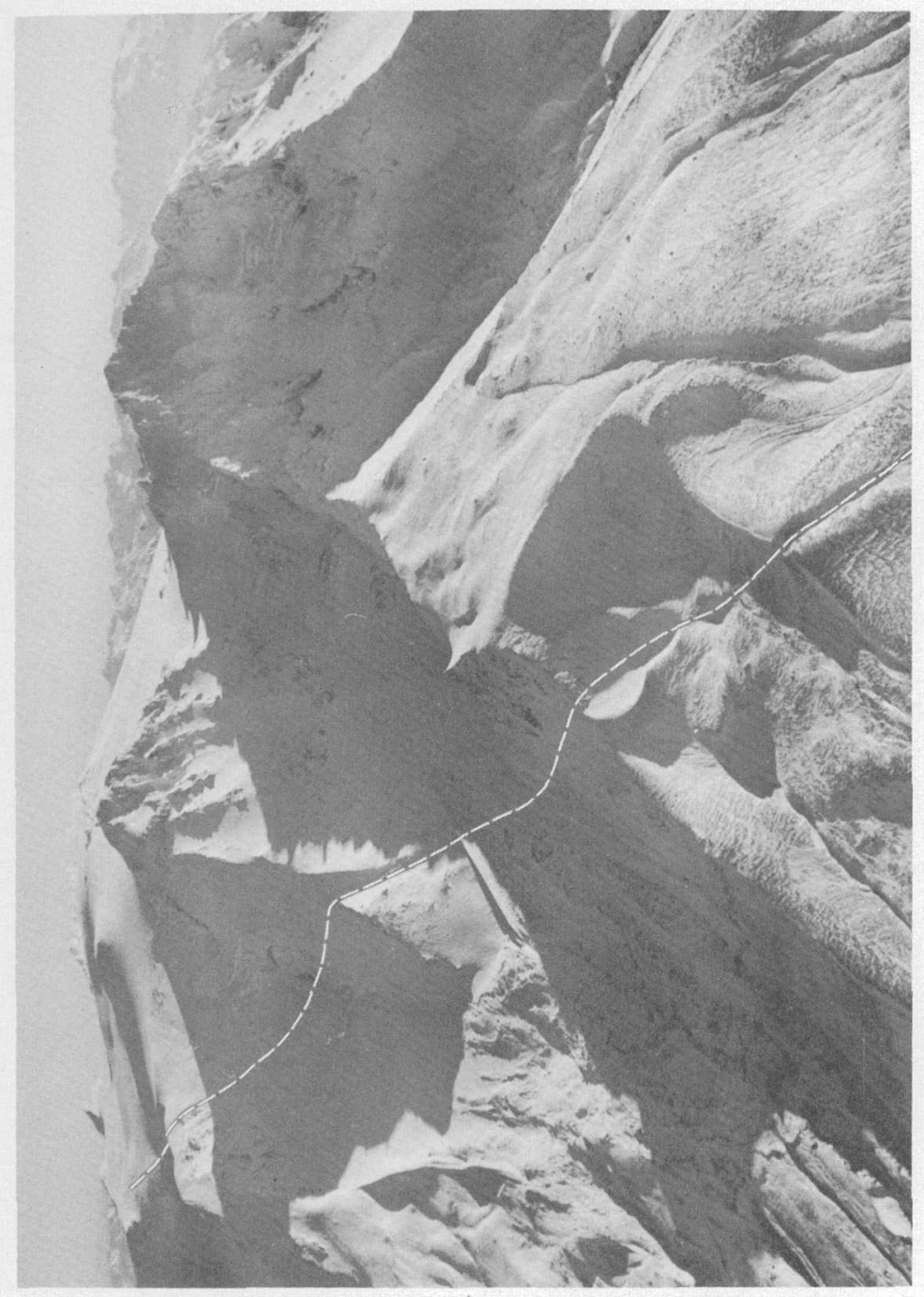

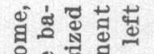
웡

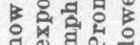
궁 졍 -

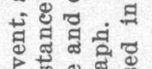
จ

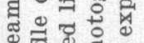

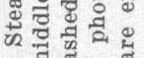

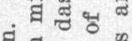

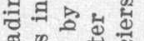
解

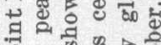
용 क एक on 0 ‡

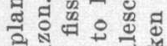
สี

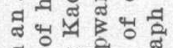

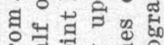
蛇宫引

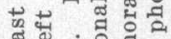
ङ 苂颌

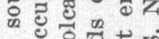
soㅇㅇㅛ 욕연 ฮึ 몽

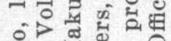
政

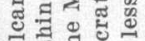
을

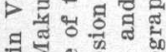
클 충 क्ष 茝 1

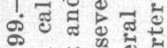

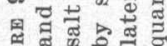
总 


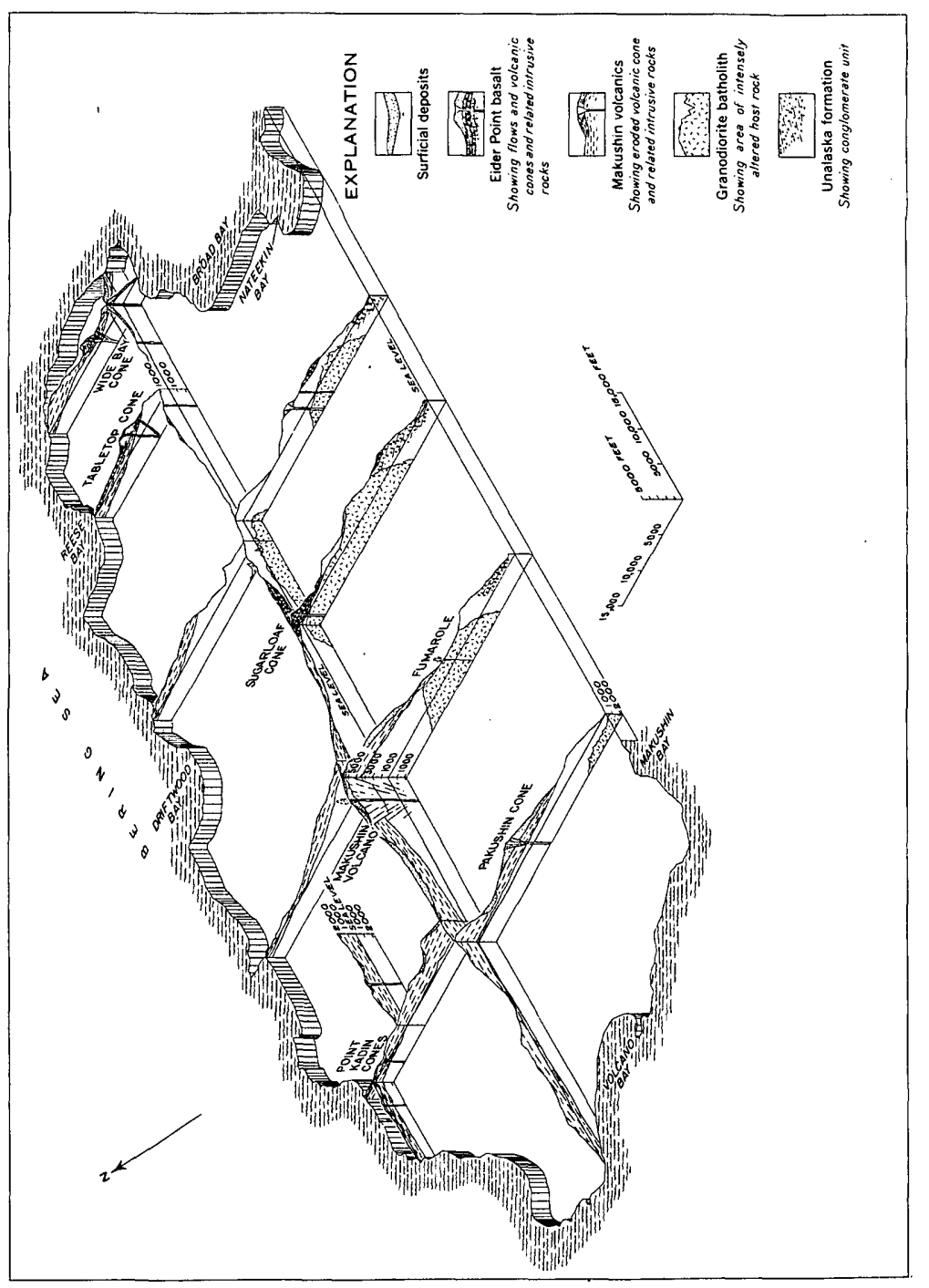

p

苟

喝

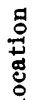

实

苛

营

总 
The configuration of the unconformity beneath the Makushin volcanics is shown on the structure contour map, figure 101. The contours are most accurately located near this unconformity; minimum elevations are shown beyond the limits of the Makushin volcanics, and maximum elevations in areas covered by that formation. As a result of these limitations, the reconstructed relief of the unconformity is subdued, and the results are wholly qualitative rather than quantitative; yet this relief is similar to that of the present land in this area.

The major ridges and valleys before deposition of the Makushin volcanics were approximately in the position of similar topographic features today. Driftwood and Glacier Valleys in particular are reflected in the drainage on the unconformity. A high area on that surface underlying Makushin Volcano may represent an original. drainage divide on the old land surface, or it may be the result of later volcanic doming of the unconformity. Using the present stand of the sea as a datum, one can say that the extrusion of Makushin volcanics has built the island several miles northward and westward.

The Makushin volcanics consist of about four-fifths basalt and andesite lava flows and one-fifth intercalated agglomerate, tuff breccia, and flow breccia. Flows 10 to 50 feet thick form small steplike cliffs on steep slopes, alternating with benches underlain by the fragmental rocks. In most places platy fractures are parallel to the flow structures, emphasizing the gentle dips, but locally these structures are erratic. The flow rocks are grayish purple to brownish gray, and the more fragmented and vesicular rocks are pale red or reddish gray. Thin ash beds and flow breccia dominate the fragmental deposits. Thicker pyroclastic and mixed pyroclastic and epiclastic units are prominent in several areas; these might serve as key beds in a detailed study. Most of the pyroclastic units are massive and unsorted; a few are well sorted and well bedded, even crossbedded or graded bedded, and contain rounded debris, incluing scattered volcanic bombs and lapilli.

Dips of flows radiate from Makushin Volcano and suggest this site as the principal vent area. The summit is an ice-filled caldera almost 2 miles in diameter, which is probably the remnant of one of the youngest vents of the Makushin volcanics. The roots of two vents and associated intrusive bodies in the Unalaska Bay area are described separately. A few dikes and, more rarely, sills intrude this basalt and andesite sequence. An unusually thick sill-like body is exposed along the coast northwest of Mount Marshal Reese.

PETROGRAPHY OF THE MAKUSHIN VOLCANICS

The Makushin volcanics are broadly uniform in texture and composition except in the few places where xenocrysts or xenoliths ap- 


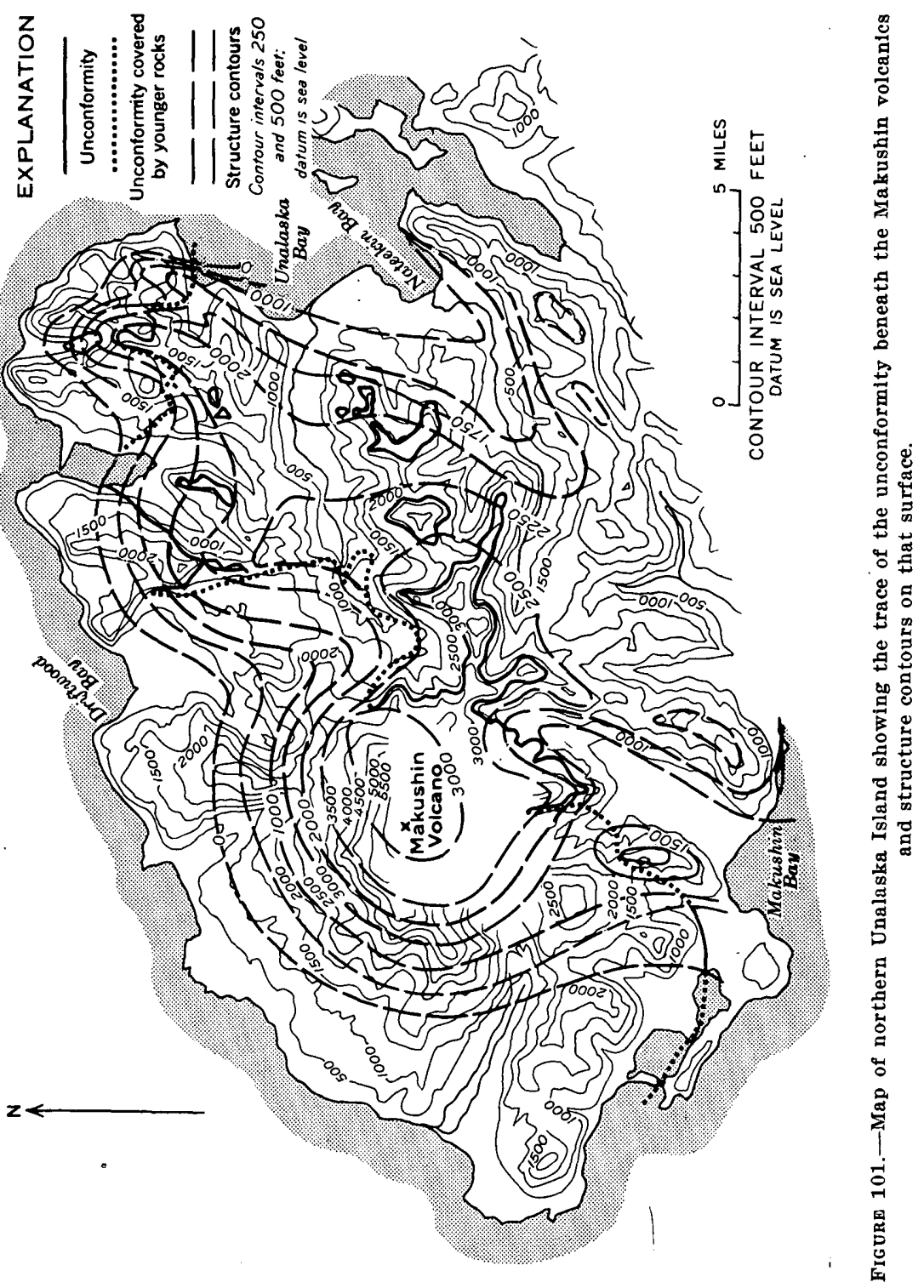


pear. Representative rocks contain between 10 and 30 percent phenocrysts, largely plagioclase but including augitic pyroxene, hypersthene, and olivine, and a few rocks contain xenocrysts or xenoliths. Felty or flow textures characterize the groundmass, the plagioclase is typically in long laths but less commonly stubby, with glassy or finely granular interstitial material. Augitic pyroxene, hereafter called augite although it may include diopside, commonly encloses hypersthene and less commonly encloses olivine in typical reaction-rim relationship.

The essential minerals are plagioclase, generally labradorite (most common), augite (abundant), hypersthene (scarce), and olivine (generally scarce, rarely abundant). Accessory minerals are magnetite, apatite, zircon, and, very rarely, amphibole and cristobalite. secondary minerals are largely pervasive hematite and limonite that obscure the groundmass of most of the fragmental and highly vesicular rocks. A few uncontaminated basalts also contain a little chlorite and zeolite.

A few of the smaller intrusive bodies associated with the Makushin volcanics have anomalous textures and compositions. The basalt intrusive complex 2 miles west of Nateekin Bay (pl. 75) contains cigar-shaped augite crystals with the $c$-axes normal to the direction of crystal elongation, which suggests strong resorption of xenocrysts. Contamination of the magma is possible, but the resorbed augite crystals are not likely to have been derived from the Unalaska formation host rock; rather they may have come from an earlier crystallized phase of Makushin volcanics.

In the cirque immediately south of this complex and on the spur a mile and a half southwest of Pakushin Cone there are small intrusive bodies of dacite and andesite. Amphibole and markedly embayed quartz and biotite crystals are present, and chlorite is abundant. Some of the large plagioclase crystals are calcic oligoclase and are mottled; the groundmass plagioclase, however, is clear sodic labradorite. The ubiquitous pyroxene and olivine of the basalt and andesite of the Makushin volcanics are absent. Presence of a basaltic magma contaminated with granodiorite could indicate the origin of these bodies, for the amphibole, quartz, biotite, and oligoclase are all common only in the plutons. Two other small intrusive bodies-one a mile northwest of Pakushin Cone and the other a mile northwest of Wide Bay Cone-are noteworthy for their relatively coarse texture; they are best described as fine-grained diorites, younger than the major plutonic masses elsewhere on the island. 
SPECIFIC DATA FOR ANALYZED ROCKS

The seven analyzed rock specimens of the Makushin volcanics are described below. The analyses show that, as a group, the Makushin volcanics have silica and alkali contents between those of the rocks of the Unalaska formation and those of the Eider Point basalt; however, there is considerable overlap in them. Chemical and spectrographic analyses appear on table 1 and additional data appear on the silica variation diagram, figure 88 .

Specimen 5 is feldspathic basalt porphyry from the Makushin volcanics $13 / 4$ miles west of Wide Bay Cone. It is light gray to medium light gray and contains pyroxene phenocrysts one-third millimeter long. Phenocrysts compose 5 percent of the rock and include augite or diopside, which forms euhedral to anhedral crystals and crystal clusters. The groundmass has a felty to coarsely crystalline texture and includes abundant subhedral laths of sodic to calcic labradorite with normal zones and faint oscillatory zones, much granular and anhedral augite(?), and subhedral and anhedral olivine and magnetite.

Specimen 6 is olivine basalt porphyry from the Makushin volcanics $41 / 4$ miles south of Tabletop Mountain and 4 miles east of Sugarloaf Cone. It is medium dark gray to grayish purple and contains plagioclase, pyroxene, and olivine phenocrysts 1-4 millimeters long. Phenocrysts compose 30 percent of the rock: 15 percent labradorite(?), which forms euhedral laths to anhedral fragments, and stubby crystals, and which contains oscillatory and normal zones, and zones of dusty inclusions; 10 percent augite or diopside, which form faintly zoned euhedral grains and fragments; 5 percent subhedral to anhedral olivine. The groundmass has a granular to flow texture and consists of abundant plagioclase, much clinopyroxene and a black opaque mineral, and traces of olivine(?) and cristobalite. Alteration is sparse; chlorite(?) replaces olivine.

Specimen 8 is olivine-bearing feldspathic basalt porphyry from the Makushin volcanics $31 / 4$ miles north-northeast of Sugarloaf Cone. It is dark gray to grayish black and contains plagioclase and pyroxene phenocrysts 1-3 millimeters long. Phenocrysts compose 25 percent of the rock : 15 percent sodic bytownite to sodic labradorite, which forms stubby euhedral crystals and fragments having faint oscillatory zones, narrow rims of normal zones, vermicular zones, zones of dusty inclusions, and apatite inclusions; 5 percent euhedral to subhedral augite( ?) ; 4 percent subhedral olivine with pseudomorphs of serpentine(?) ; 1 percent hypersthene with augite reaction rims; and a trace of anhedral magnetite. The groundmass has intergranular texture and includes abundant subhedral laths and stubby crystals of sodic bytownite to sodic labradorite, and much granular augite(?) and a black opaque mineral. Alteration is sparse; 3 percent of the rock is chlorite(?), which replaces olivine.

Specimen 10 is olivine-bearing feldspathic basalt porphyry from Makushin volcanics 1 mile northeast of Pakushin Cone. It is pale purple to grayish purple and contains plagioclase, pyroxene, and olivine phenocrysts $1-1$ millimeters long. Phenocrysts compose 25 percent of the rock: 15 percent sodic labradorite, which forms euhedral stubby crystals and fragments, and which contains faint oscillatory and normal zones, zones of dusty inclusions, and apatite inclusions ; 6 percent euhedral to subhedral augite (?) ; 2 percent hypersthene with thin augite(?) reaction rims; 2 percent euhedral to anhedral olivine; and 1 percent subhedral magnetite(?), with some myrmekitic intergrowth in augite(?). The groundmass has a felty to intergranular texture 
and consists of sodic labradorite, abundant subhedral laths and stubby crystals of much granular augite( ?), a black opaque mineral, and a trace of granular olivine.

Specimen 11 is olivine-bearing basalt porphyry from Makushin basalt and andesite $2 \frac{1}{2}$ miles southwest of Pakushin Cone. It is pale purple to medium light gray and contains plagioclase, pyroxene, and olivine phenocrysts 1-2 millimeters long. Phenocrysts compose 15 percent of the rock : 9 percent labradorite, which forms euhedral to subhedral stubby crystals having normal and oscillatory zones ; 2 percent subhedral augite (?) ; 3 percent anhedral olivine with augite(?) reaction rims ; 1 percent subhedral to anhedral and embayed magnetite(?). The groundmass has crudely trachytic to intergranular texture and includes abundant subhedral laths and stubby crystals of calcic labradorite, much granular augite (?) ; a trace of a granular opaque mineral, and a trace of cristobalite(?). Alteration is slight; olivine and magnetite(?) alter to hematite and limonite.

Specimen 16 is olivine-bearing andesite porphyry from the Makushin volcanics one-half mile south of the vent to Makushin Volcano. It is dark gray and vuggy and contains plagioclase and pyroxene phenocrysts $2-3$ millimeters long. Phenocrysts compose 25 percent of the rock: 14 percent sodic labradorite, which forms euhedral to anhedral grains, fragments, and stubby crystals, and which has normal and oscillatory zones, zones of dusty inclusions, and apatite inclusions; 5 percent euhedral crystals and fragments of augite(?) ; 2 percent subhedral to anhedral hypersthene with augite(?) reaction rims; 3 percent anhedral olivine; and 1 percent subhedral to anhedral magnetite. The groundmass has an intergranular to obscured texture and includes abundant laths and stubby crystals of calcic andesine, much glass and granular augite(?), and traces of hypersthene, olivine, and a granular black opaque mineral.

Specimen 18 is andesite porphyry from the Makushin volcanics 3 miles southeast of Sugarloaf Cone. It is medium gray to purplish gray and contains plagioclase and pyroxene phenocrysts 1-4 millimeters long. Phenocrysts compose 20 percent of the rock: 12 percent andesine to bytownite, which forms euhedral laths and fragments, and which has normal and oscillatory zones, zones of dusty inclusions, and apatite inclusions; 5 percent augite(?), which forms euhedral to anhedral grains, crystal clusters, and reaction rims around hypersthene; 2 percent subhedral hypersthene with reaction rims; a trace of anhedral olivine (?) ; a trace of subhedral to anhedral magnetite; and a trace of euhedral apatite. The groundmass has a felty to flow texture and includes abundant subhedral andesine laths, much augite(?), and a trace of a granular black opaque mineral.

\section{AGE OF THE MAKUSHIN VOLCANICS}

Most of the Makushin volcanics are believed to be middle to late Pleistocene in age, if the method of dating the insular shelf, presented below, is accepted. If the dating of the insular shelf proves unsatisfactory, then the lower age limit of the Makushin volcanics is set by the late Miocene or Pliocene batholith which intruded the Unalaska formation. The basalt and andesite is extensively glaciated and must precede at least part of late Pleistocene time.

\section{EIDER POINT BASALT}

Numerous small volcanic cones, associated volcanic mudflows, and lava flows that largely retain details of their constructional forms 
are scattered about the northern bulge of Unalaska Island. One of these cones is still active. These young rocks lie unconformably on the deeply dissected surfaces of Makushin volcanics or older rocks. The rocks from these vents are not contemporaneous, but a chronology is not available. These rocks are here named the Eider Point basalt, for the rocks of Wide Bay Cone above Eider Point are typical of the unit.

Rocks of the Eider Point basalt resemble those of the Makushin volcanics; flows of both units are grayish purple to brownish gray and relatively thin, but the younger flows are less continuous. The constructional forms and, in places, conspicuous basal unconformities are the chief distinguishing features of the Eider Point basalt. Pyroclastic deposits, usually separate cones, are far more conspicuous in the younger rocks than in the Makushin volcanics. Phenocrysts are ubiquitous and compose on an average 20 percent of the volume. Felty or flow textures are most common, and vuggy and vesicular structures abundant. Sodic bytownite or labradorite plagioclase, augite, olivine, and in some rocks hypersthene are the essential minerals; magnetite and apatite are the chief accessories.

\section{MAKUSHIN VOLCANO; FUMAROLES AND HOT SPRINGS}

A small cinder cone and remnants of other probable cones project. through the ice field within the summit caldera of Makushin Volcano (fig. 99). Scoriaceous basalt from this cone is typical of the Eider Point basalt. Photographs of the summit of Makushin Volcano showing Makushin cone and fumaroles are presented by Freiday (1945, p. 448-449).

Scattered about the main vent are several fumaroles and much sulfur and sulfur-impregnated clay. This sulfur is discussed under the heading "Economic geology." Gases from the vent area are largely water vapor; some $\mathrm{H}_{2} \mathrm{~S}$ and probably $\mathrm{SO}_{2}$ are emitted. Occasional minor amounts of ash accompany the gases and discolor the snow about the vent, which has been mildly active since 1826 (Coats, 1950, table 2).

A large fumarole area is active at the head of Glacier Valley about 3 miles southeast of the summit vent, and a smaller fumarole area lies 2 miles south of the summit. Hot springs are found in these areas, and also on the east side of the valley bottom $1 \frac{1 / 2}{2}$ miles from the shore of Summer Bay, some 20 miles from Makushin Volcano.

\section{PAKUSHIN CONE}

A basalt composite cone lies midway between Makushin Volcano and Makushin Bay. The base of this cone has an elevation of about 2,000 feet, and its multiple-cratered summit reaches an elevation of 
3,395 feet. Ash and cinders from this cone are draped over bordering knobs of older rocks and fill adjacent valleys. Low on the northeastern flank some of the lava flows from Pakushin Cone are slightly glaciated, probably in Recent time during a period of expansion of the icecap. The vitric groundmass contains an unusually large percentage of phenocrysts, of which the plagioclase phenocrysts are nearly all equidimensional. Olivine exceeds 15 percent of the rock volume.

\section{POINT KADIN VENTS}

Ten small cones and explosion craters lie on a rift zone trending N. $75^{\circ}$ W. northwest of Makushin Volcano (fig. 99). Several of these consist of multiple craters; others form elongate fissures. Remnants of the original rim of the largest of these craters are marked by alined ledges of agglutinated lava. Fragments of Makushin volcanics, in this area lighter in color and conspicuously porphyritic, appear among the ropy and scoriaceous ejecta on the low cones.

North of this line of vents as far as Koriga Point the flows, agglomerate, and most of the ejecta are dark-gray, vịtreous to cryptocrystalline olivine-free rocks. All of these flows have well-developed flow structures and some contain inclusions with porphyritic feldspar. The composition of these rocks cannot be estimated from petrographic study, but a chemical analysis of one vitrophyre, analysis 21 , shows that the specimen is andesite with some affinities toward dacite.

The very fresh constructional forms of these vents and the lack of glacial erosion of those away from the present ice limit indicate that they are very young features and certainly postglacial. This age is verified by comparison of the offshore profile here, which has only a suggestion of a submarine bench, with that of Makushin Bay, which has a wider postglacial submarine bench. They need be no older than a few thousand years.

\section{BISHOP POINT VOLCANIC MUDFLOW}

The valley south of Bishop Point contains a terrace about 100 feet above the dissecting streams, the surface of which slopes seaward unscarred by streams. The agglomerate forming this terrace is massive and internally structureless, contains abundant cinders, and overlies the basalt and andesite flows of the Makushin volcanics. It is probably a volcanic mudflow formed at a relatively recent time. The mantle of soil and volcanic ash and cinders contain only the upper two of the three distinctive ash-cinder layers characteristic of this area, and it is conceivable that the mudflow was contemporaneous with the lowest of the three layers. A heavy ash-cinder fall blanketing the icefields at the head of the valley south of Bishop Point could readily 
have become mobilized and could have incorporated much glacial till enroute to the lower part of the valley.

\section{SUGARLOAF CONE AND LAVA FLOWS}

The upper reaches of Driftwood and Makushin Valleys contain unaltered lava flows and pyroclastics. Along the drainage divide between these valleys is a small cinder cone called Sugarloaf Cone by Jaggar (1908, p. 11). The flows, which are older than the cinder cone, dip away from this divide, which may be their vent area.

Sugarloaf Cone consists of steeply outward dipping, crudely bedded pyroclastics unconformably capped by well-bedded, gently inward dipping clastic beds. This unconformable cap suggests the remnant of a crater fill with well-reworked pyroclastics, which may have been deposited in part in a pond. The remnant of the cone also shows that a considerable outer portion of the cinder cone has been removed without destroying its conical form, for the crater rim that contained the pond is missing.

The composition of the vuggy flows and pyroclastics associated with Sugarloaf Cone is characteristic of the younger basalt except that ". olivine, hypersthene, and augite form reaction rims in almost every combination about each other. Reaction rims in accord with Bowen's reaction series as well as those abnormal to it occur in the same thin section. One clinopyroxene grain is surrounded by grains of olivine, and outside of these is another thin rim of clinopyroxene. Several varieties of plagioclase phenocrysts occur in the same thin section, some clear and others with clouded cores or zones.

Prior to extrusion of the flows around Sugarloaf Cone the upper basin of Makushin Valley probably drained into Driftwood Valley, for the unconformity at the base of these flows conforms to that valley. This old drainage also explains the disproportionate width of upper Driftwood Valley in relation to its present drainage area. These lavas were overriden by jce-they bear glacial striae and roches moutonées-during a late glacial advance, after which Sugarloaf Cone was formed.

CONE AND LAVA FLOWS OF TABLETOP MOUNTAIN

Tabletop Mountain is a pyroclastic cone surrounded by flows originating from small flank domes, and like Sugarloaf Cone is capped by well-bedded pyroclastics and reworked poorly indurated sandstones dipping gently inward. The truncated outer edge of this crater fill and the several dikes projecting from the slopes of the cone indicate that it is considerably eroded. Coalescent summit depressions may indicate volcanic subsidence at the end of its explosive history. The flows are vuggy and contain a little more olivine and augite than the 
average Eider Point basalt. These flows have also been slightly glaciated and presumably are of late Pleistocene age.

\section{WIDE BAY CONE}

A small, symmetrical composite cone overlies rocks of the Unalaska formation and Makushin volcanics north of Wide Bay. Its summit crater is essentially unfilled and the outer slopes of the cone are largely intact, for individual flows may be traced from the crater edge to the base of the cone. The flows west of the cone cover the floor of a cirque, but their toes are slightly abraded by glacier movement. The flows resemble those of Tabletop Mountain: they are vuggy and contain prominent olivine and augite phenocrysts, which are more abundant than in the average Eider Point basalt.

\section{OTHER POSSIBLY YOUNG FLOWS}

On the south wall of Nateekin. Valley, $21 / 2$ miles from the head of the bay, is a possibly young basalt flow with what appear to be push moraines and lateral levees. Although containing chlorite and uralite, it is much less altered than the adjacent rocks of the Unalaska formation. The flow contains aplitic inclusions, rich in quartz and biotite, and contains amphibolite xenocrysts. Possibly the amphibole and even the uralite and chlorite are derived from inclusions. Contamination of the basaltic magma by quartz-rich granodiorite, such as occurs at nearby Captains Bay, may explain these xenoliths and xenocrysts.

On the bluft above the mouth of McLees Lake is a small dome and lava tongue that suggests a young flow. In the possible vent area scoriaceous slabs dip outward. The rock is petrographically similar to the adjacent Makushin volcanics.

\section{PETROGRAPHy OF THE EIDFIR POINT BASALT}

SPECIFIC DATA FOR ANALYZED ROCKS

Chemical and spectrographic analyses of five rocks of the Eider Point basalt appear on table 1 .

Specimen 3 is olivine basalt porphyry from a flow of Eider Point basalt 1 mile northeast of Tabletop Mountain. It is grayish red purple to medium gray and contains plagioclase phenocrysts as Iong as $1 \mathrm{~mm}$. Phenocrysts compose 20 percent of the rock: 10 percent bytownite, which forms euhedral laths, stubby crystals, and fragments, and which has normal zones, apatite inclusions, and rare vermicular inclusions; 5 percent augite(?), which forms euhedral to subhedhral crystals and crystal clusters, and which has apatite inclusions; 5 percent subhedral to anhedral and embayed olivine. The groundmass has an intergranular texture, with stubby crystals and 25 percent vugs, and consists of abundant euhedral to subhedral plagioclase, much subhedral to granular augite(?) and a black opaque mineral, and a trace of olivine. Alteration is sparse; olivine and the black opaque mineral alter to hematite and limonite.

Specimen 4 is olivine basalt porphyry from an Eider Point basalt flow threefourths mile southwest of Wide Bay Cone. It is medium gray and vuggy, and 
contains pyroxene and olivine phenocrysts 1-4 millimeters long. Phenocrysts compose 20 percent of the rock : 10 percent sodic bytownite, which forms euhedral laths, stubby crystals, and fragments, and which has normal zones, rare oscillatory zones, zones of dusty inclusions, and apatite inclusions ; 5 percent augite(?), which forms euhedral to anhedral grains and embayed crystals, and which is faintly zoned; and 5 percent olivine, which forms subhedral to anhedral crystals and embayed crystals. The groundmass has an intergranular texture and consists of abundant stubby subhedral calcic andesine, much granular clinopyroxene and a black opaque mineral, and traces of olivine and tridymite.

Specimen 7 is olivine-bearing feldspathic basalt from the Eider Point basalt 1 mile southwest of Pakushin Cone. It is medium dark gray and contains plagioclase phenocrysts shorter than $1 \mathrm{~mm}$. Phenocrysts compose 50 percent of the rock : 35 percent sodic labradorite, which forms subhedral crystals and stubby crystals, and which has normal zones, rare oscillatory zones, and some vermicular zones of intergrown groundmass; 15 percent olivine, which forms euhedral to subhedral crystals and embayed crystals. The groundmass has a granular and glassy texture and consists of much euhedral stubby calcic andesine, much subhedral to anhedral olivine, much euhedral to granular augite(?), and a trace of cristobalite( ?).

Specimen 12 is olivine-bearing andesite porphyry from a flow in the Eider Point basalt $1 / 2$ mile southeast of Sugarloaf Cone. It is medium gray and contains plagioclase, olivine, and pyroxene phenocrysts 1-3 millimeters long. Phenocrysts compose 30 percent of the rock: 15 percent calcic andesine to sodic labradorite, which forms embayed crystals, euhedral laths, and fragments, and which has normal and oscillatory zones, zones of dusty inclusions, and apatite inclusions; 10 percent euhedral to anhedral augite(?), of which one crystal has a reaction rim of granular olivine, one crystal has an inner rim of granular olivine and an outer rim of clinopyroxene, and one crystal has a clinopyroxene rim; 3 percent subhedral hypersthene, which has augite(?) reaction rims, and one crystal of which has an olivine(?) and myrmekitic magnetite(?) rim; and 2 percent anhedral olivine with clinopyroxene reaction rims. The groundmass has a felty to granular texture and consists of abundant subhedral labradorite, much clinopyroxene and granular olivine(?), and traces of a granular black opaque mineral and cristobalite.

Specimen 21 is andesite vitrophyre from a flow of Eider Point basalt 4 miles northwest of Makushin Volcano. It is grayish black and contains plagioclase phenocrysts as large as 1 millimeter in sheeted and finely vesicular glass. Phenocrysts compose 1 percent of the rock and include euhedral to fragmental labradorite and traces of clinopyroxene and magnetite. The glassy groundmass has alined microlites, dusty inclusions, and strong flow bands of light and dark streaks, and contains some euhedral cristobalite on vesicule walls.

\section{SURFICIAL DEPOSITS AND GEOMORPHOLOGY}

\section{GLACIAL LANDFORMS AND DEPOSITS}

Landforms showing glacial erosion are very prominent on Unalaska Island. In the mountainous parts of the island there are U-shaped valleys and passes, cirques and arêtes, and ice-scoured features of every size. Benches that slope gently seaward are perched at various elevations on the walls of many of the glaciated valleys; these may be zones of structural weakness accentuated by glacial 
scour. The benches along the east wall of Anderson Bay disregard the observable structure; they have been ascribed by Jaggar (1908, p. 32, 33, pl. facing p. 35; written communication, 1927) to marine erosion but are probably best explained by glacial scour. Many cirques hang above the main valley floors; some contain rock-basin lakes, and some high valleys contain several levels of cirques, which are separated steplike by steep walls. The erosional forms of this glaciated topography are little altered by postglacial erosion and probably reflect a late stage of Pleistocene glaciation.

Small glaciers fill the basins in the high peaks of the Shaler Mountains; an ice field of 15 square miles caps Makushin Volcano. The glacier covering $1 / 2$ square mile, 3 miles, 3 miles south of Naginak Cove of Anderson Bay descends to about 2,000 feet. In the valley west of Makushin Volcano a glacier reaches (1954) as low as 700 feet; it is till veneered below 1,200 feet and bare ice above. Smaller glacial tongues northwest of the volcano showed bare ice at about 3,000 feet in 1954, with buried ice below 2,000 feet. Crevassed surfaces are common to most of the tongues about the ice cap and to the other small glaciers. Semipermanent snow fields are common above 2,500 feet.

The snowline during maximum Pleistocene ice advance is estimated to have been at least as low as 1,200 feet in elevation; possibly it was as low as 400 feet. On the rugged part of the island, few cirques occur below 1,200 feet, but on the extreme eastern and western ends of the island, where the topography is more subdued, poorly developed cirques are found as low as 400 feet. Small cirquelike features at 500 feet on the north side of the island may owe their form to artesian sapping in flat-lying young volcanics. If one considers the lowest cirque floors as indicating a Pleistocene snowline (Sharp, 1938, p. 312 ), the relations indicate a minimum elevation of that snowline of between 400 and 1,200 feet. A similar estimate was made by J. P. Schaefer (written communication, 1955) for Attu Island.

The present snowline lies near 3,000 or 4,000 feet, the estimate varying with allowances for past climate and annual variations in weather. The photographs of the ice cap on Makushin Volcano taken by Freiday $(1945$, p. 448 and 450$)$ in September 1944, a particularly warm summer, provide the best basis for such an estimate and show the upper limit of abundant bare ice to be about 3,000 feet. Where abundant ice patches appear through the névé, ablation exceeds accumulation, and the upper limit of this defines the snowline. During still warmer summers, bare ice may appear as much as 1,000 feet higher. A rise of the snowline since the maximum Pleistocene glaciation of 2,000 to 3,000 feet is indicated. 
At the lower ends of the glaciers northwest of Makushin Volcano, two minor moraines reflect recent fuctuations of the ice position. In the valley south-southwest of Koriga Point, for example, the highest and youngest of these moraines forms an unbroken, lobate ridge of coarse rubble, 5 to 10 feet high. No vegetation grows on this moraine, and ice patches appear nearby beneath the till mantle. A few hundred yards farther down the valleys, a second, more subdued moraine of youthful appearance parallels the first, and is covered sparsely by mosses and flowering plants. Both moraines rest on the Point Kadin flow, which follows this valley. Above the lateral moraines associated with these terminal moraines there is more till, which extends farther down the valley. The extremely fresh appearance of these moraines and their close proximity to existing glaciers indicates that they represent small advances or pauses during recession, perhaps a few hundred years old. Comparable fluctuations of glacier margins are recorded on Umnak (Byers and others, 1947, p. 35, 38), Great Sitkin (Simons and Mathewson, 1947, p. 65, pl. 4; 1955, p. 33, pl. 5), and Attu (Schaefer, written communication, 1955).

Many cirque bottoms contain irregular mounds of till consisting of coarse blocky debris without appreciable interstitial fine material. This young glacial debris is perhaps another product of Recent glaciation. Other till, particularly in the lower cirques, probably dates back to the latest Wisconsin ice advance. A thin veneer of ground moraine covers parts of the island but is absent in the rugged interior. Till is well exposed in road and building cuts in the vicinity of Unalaska village and the military bases, is stony, has a matrix of clay and silt, and is plastered against depressions in the bedrock surface. Elsewhere exposures of such till are few. The reconnaissance nature of the mapping prohibited the general mapping of the till, but most of the till was deposited below sea level.

\section{STREAM EROSION AND ALLUVIUM}

Postglacial stream erosion has produced abundant steep-walled, narrow-bottomed ravines and gorges. The most characteristic feature of the large valleys, exclusive of those draining the large existing glaciers, is their steplike long profile, broken by rock spurs. Some rock-basin lakes have been alluviated. Alluviation is conspicuous and erosion of bedrock valley bottoms less important in valleys below existing large glaciers:

Alluvial fans deposited by tributaries on the bottoms of the main valleys are conspicuous, especially where the main streams are not burdened with outwash. Alluvial deposits grade upward into colluvium, talus debris, and, in places, till. Downstream, alluvium 
grades into beach deposits and, in some valleys, into lagoonal or deltaic deposits.

The rivers draining Makushin Volcano are burdened with glacial outwash; their valleys are wide and flat bottomed, with markedly braided channels and distributaries where outwash is being deposited. Vegetation is scarce and young in areas of outwash, and the frequently shifting channels keep resurfacing the valley floor. In the lower half of the wide part of Makushin Valley a thick sod cover and tall-over 6 feet-willows are common; distributaries are few and the channel not braided. Willows grow on the streamside levees, but the flats away from the channel are grass covered and swampy. Overbank floods add silt and mud to these swamps, but floods affect the channel position more rarely in the lower part of the valley than in the outwash-choked segment. The upper reaches of many of the larger valleys are flanked by terrace remnants of outwash gravels. Till is exposed at the base of such an alluvium-capped terrace at the head of the broad-valley segment of Makushin Valley.

\section{COLLUVIUM AND EOLIAN DEPOSITS}

Surficial deposits in the alluvial or till-filled valleys consist of an assortment of material derived largely from mechanical disintegration of rock, with admixtures of ground moraine and layers of ash, lapilli, and cinders. Ash probably is intercalated in soils of every valley on the island; Recent pyroclastics are most conspicuous in the northern bulge of the island and to a lesser extent on the extreme western end of the island. This distribution clearly reflects the proximity of a center of explosive volcanic activity on Unalaska Island and one on eastern Umnak Island. Kellogg and Nygard (1951, p. 45-46, map) describe one soil section at Dutch Harbor as consisting of dominantly reddish-brown and yellowish-brown silt loam and loam. They classify the soils as tundra and bog soils without permafrost at lower elevations, and as lithosols on rock and above about 1,000 feet.

Creeping and sliding mantle is extensive because of abundant moisture and steep slopes. Solifluction terraces and, in flat areas with Jittle vegetation, stone stripes are widespread indicators of gradual downhill movement of the mantle. More rapid movement is indicated by the turf-covered lobate mudflows that in places exceed 1,000 feet in width. Flows and landslide scars are particularly common on glacially steepened valley walls. Mounds of landslide debris and ponds filling depressions produced by impact of landslides on boggy ground occur along the edges of some of the alluvial valleys, as for example along the north wall of Makushin Valley. Along steep 
slopes, particularly sea cliffs and cirque headwalls, talus cones and aprons are prominent. The above-mentioned surficial deposits are not mapped separately.

\section{SOILASH PROFILES}

Soil-ash profiles are helpful in reconstructing some of the postglacial, prehistoric eruptive history of the volcanoes. Most of the sporadic volcanic eruptions are probably older than the arrival of pre-Aleut people over 4,000 years ago (Laughlin and Marsh, 1951, p. 82); for only a few thin ash layers are found in the midden sites.

Undisturbed and complete soil-ash profiles are most readily found along small streams incised into the floor of cirques at low elevations. A few sections are exposed by marine and eolian action. Major valley bottoms contain too thick a cover of alluvium and muck to provide such sections. In thin ash layers the thickness of the layer should be useful for correlations, for the ash would not bury the vegetation and drift freely, but in thick ash layers the fragment size may be a better correlating criterion than the thickness of the layer.

All profiles are from near Unalaska Bay and details of color and grain size of the soil and ash layers are not presented (fig. 102). Soil profiles in widely separated localities are grossly similar, but only those clustered together can be correlated with even fair reliability. In general the soil is progressively looser and more humic upward and contains more clay downward. Clay layers range in color from yellowish gray to orange, reddish brown, olive gray, and bluish gray. Bluish clays are common with till; reddish ones may be associated with limonite-rich bog deposits. The ash and cinder layers are generally medium gray or yellowish gray to orange, and perhaps some yellow clays are decomposed ash. Bombs and lapilli are scoriaceous, and some layers contain pumiceous lapilli. The bombs from the lowest pyroclastic layer in section $C$ contain a few phenocrysts of bytownite, hypersthene, and other ferromagnesian minerals, and are similar to the pyroclastics of the Eider Point basalt.

Since the last deposition of glacial till at altitudes below most small cirques, several major episodes of explosive activity are recorded in each section, as indicated by the thick layers of coarse bombs and lapilli. The upward decrease in grain size of pyroclastics points to a gradual decrease in violence and frequency of eruptions. The areal changes of size of pyroclastics and the abundance of pyroclastic layers indicates the source of some or most of this material lies in the western part of the northern bulge of the island, but some of the fine ash layers might have had a more distant source than Unalaska Island. 


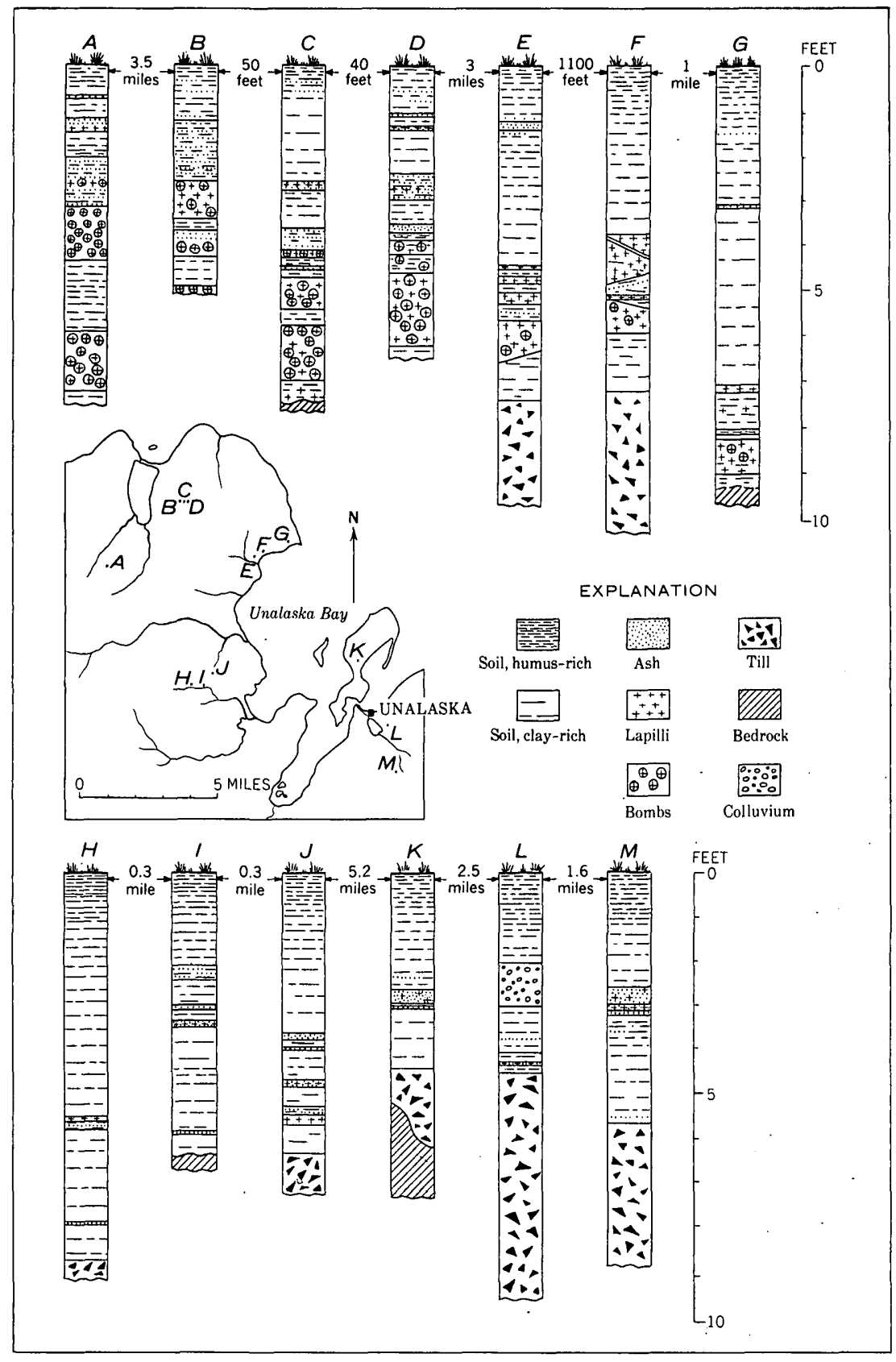

Fiadre 102.-Soll-ash profles. 


\section{EOLIAN FEATURES}

Depressions produced by deflation are prominent on the lower, western end of Unalaska Island, around the northern flank of Makushin Volcano, and on exposed ridges that have some vegetation cover. The bottoms of some of the larger pits are partly covered by pebble pavement; where coarse pyroclastics appear in the mantle these form lag deposits.

Dunes have formed behind a few large sand beaches, their apparent sources. The largest dune areas are in Surveyor Bay, the bay east of Cape Aiak, and Volcano Bay. The innermost area of dunes at Surveyor Bay has an unbroken cover of vegetation and is probably stable. The seaward edges of dunes nearest this bay and those east of Cape Aiak are partly destroyed by marine attack; grass-capped hummocks, 10 or more feet high, form isolated residual dunes.

\section{MARINE EROSION AND DEPOSITS}

Cliffs surround most of Unalaska Island, indicating the importance of marine erosion. Hanging valleys abound along most headlands exposed to direct wave attack for in such settings stream erosion is subordinate to marine erosion. Cliffs that are continuous with sea cliffs border the edges of some large fiords for a considerable distance inland, suggesting that prograding is changing the shoreline position in places. Wave-cut rock benches, emergent during low tide, are conspicuously present along moderately protected shores (fig. 87) but absent from shores completely protected from waves.

Beach deposits, ranging from boulders to sand, are prominent in the heads of all but the most protected bays, and thin strips of beach deposits commonly separate tidal benches from the sea cliffs. The latter deposit is undoubtedly of transient debris, locally derived. Beach berms at various low altitudes and variously prominent are common to those bays which are open to wave attack and not hampered by excessive alluviation or outwash deposition.

Bars and spits are built across many of the shallow bays. Cuspate spits along the sides of Pumicestone and Kulitiak Bays and at Eider Point represent the earliest stage. The spit at Dutch Harbor, representing a later stage, is almost $11 / 2$ miles long and reaches the middle of Iliuliuk Bay. The bar across Staraya Bay may just have been completed and is subject to spillover by storm waves, for during the last 17 years, as indicated by two sets of aerial photographs, part of the lagoon side of the bar has been built higher and wider. This lagoon is still brackish and its level fluctuates with the tide. The bar across Reese Bay also appears very youthful, for at its western end the bay and lagoon are separated by only a narrow boulder bar- 
rier. The asymmetry of the plan of the spits that have joined at this narrow section of the bar indicates that the strong longshore current is westward. It is also noteworthy that during at least one storm in the last 15 years, waves spilled over the bar into the lagoon without breaching the bar; for large sections of a floating steel dock, part of an army installation, were tossed to the top of the bar and across its narrow section. This lake was connected to the sea, according to the inhabitants of the place as reported by Grewingk (1850, p. 121), and is thus about 150 years old. Completed stable bars include those at Volcano, Summer, and Hive Bays. Continued prograding of bars, as at Kalekta Bay (Freiday, 1945, p. 446), Staraya Bay, and Protection Bay, produces a wide, stable bar area, and eventually the lagoons are filled by alluviation. In other valleys, alluvium and beach deposits gradually fill the bay without development of a bar or lagoon. Amaknak Island consists of three high rocky masses joined by bars, and Cape Kalekta and a small island at Kashega are joined to Unalaska Island by narrow bars.

Evidence of sea-level change is scanty. There are a few suggestions of a marine terrace between elevations of 350 and 400 feet. A bench at Cape Kovrizhka is 1 mile wide and contains closed depressions that might represent irregularities in a wave-cut platform. Possible additional remnants of a terrace occur in the English Bay area and on Unalga Island a few miles east of Unalaska Island. This may be a single surface which is tilted gently eastward; it is about 200 feet in elevation on the east side of Unalga Island and 1,200 feet east of Agamgik Bay. The relatively flat-capped promontories at, and west of, Alimuda Bay (fig. 82) may reflect a much-dissected marine terrace.

\section{STRUCTURAL GEOLOGY}

The Aleutian Ridge, marked above sea level by the Aleutian island arc, is bordered on the south by the Aleutian Trench, which lies on an average 28,000 feet below the island peaks and 1,000 to 10,000 feet below the adjacent floor of the Pacific Ocean, and on the north by the Bering Basin, more than 6,000 feet deep.

On Unalaska Island, bedding dips are generally less than $30^{\circ}$ and average $15^{\circ}$. The rocks are nearly horizontal in the western and northeastern ends of the island. East of Kashega, northward dips are dominant in the exposed older rocks. Along the northern shore near Alimuda Bay and Station Bay, the rocks dip northward $10^{\circ}$ to $15^{\circ}$ on the north side of a gentle anticline which parallels the coast. Local flexures are known in the Unalaska formation, but the abundance of fractures and probable faults and poor stratigraphic con- 
trol make interpretations of folds suspect. For example, along the south shore of Captains Bay the rocks dip gently southward for the first $1 \frac{1}{2}$ miles from the head of the bay; beyond a covered interval $1 / 2$ mile wide the rocks dip gently northward as far as Unalaska village. This structure may be an anticline, or may indicate tilted fault blocks.

Within a mile-wide zone along the southeastern contact of the Shaler batholith, the Unalaska formation dips variably and more steeply than elsewhere. Some of the rocks are sharply truncated by the batholith. Strata more than a mile from this section of the contact have a persistent gentle southward dip. Along the northeastern and southwestern borders of the batholith, dips are away from the batholith. Along the irregular northwest border, the regional northward dip prevails. The variable dips around the Shaler batholith may have originated by forceful intrusion of magma, with some outward and upward displacement of contact rocks, or may represent a terrain disrupted by fault jostling into which the magma passively stoped or fluxed its way. The Shaler batholith and, to a lesser extent, the other plutons control the overall shape of the island at the places where they occur. The Shaler pluton is protected from the sea by a carapace of Unalaska formation rocks about 5 miles wide, except for the narrow bays which dissect it to its core. This may reflect the original shape of the island when it was initially uplifted above sea level or may be the result of differential erosion of a much larger uplifted island.

\section{FAULTS}

Faults, joints, and related linear features are abundant (pl. 77), but the length, direction, and amount of displacement are known for only a few of them. Most of the faults are nearly vertical; low-angle faults have not been recognized.

The faults range from tight fractures to those with strongly sheared zones or minor amounts of breccia. Some faults are mineralized slightly with some combination of quartz, pyrite, and calcite.

The strong topographic alinement of Beaver Inlet, Erskine, Portage, and Makushin Bays bisects the island and suggests a major fault. If the Beaver and Captains plutons are parts of a single small batholith, more contaminated by mafic argillites along the southern border and separated by roof rocks near Uniktali Bay, then possible horizontal displacement on the fault is north side 6 miles west. This is supported by the alteration patterns shown in figure 89. Positive evidence for this fault has not been discovered in the valley between Portage Bay and Erskine Bay but exposures are poor in this area.

There is little regional consistency to the known faults, listed on table 3, except that they are steep normal faults. 
TABLE 3.-Unalaska Island faults and their displacements

\begin{tabular}{|c|c|c|c|c|}
\hline Location & Strike & $\begin{array}{c}\text { Amount } \\
\text { vertical } \\
\text { displace- } \\
\text { ment } \\
\text { (feet) }\end{array}$ & $\begin{array}{l}\text { Down- } \\
\text { thrown } \\
\text { side }\end{array}$ & Age \\
\hline Cape Aiak, north fault. & \multirow{5}{*}{$\begin{array}{l}\text { ENE. } \\
\text { ENE. } \\
\text { NE. } \\
\text { N.65\% W. } \\
\text { WNW. }\end{array}$} & 40 & \multirow{5}{*}{$\begin{array}{l}\text { N. } \\
\text { N. } \\
\text { NW. } \\
\text { s. }\end{array}$} & \\
\hline Cape Aiak, south fault & & 600 & & \\
\hline $\begin{array}{l}\text { Mount Kimble, southeast of Chernof- } \\
\text { ski Harbor (2 faults) }\end{array}$ & & & & \\
\hline $\begin{array}{l}\text { Ridge north of Makushin Valley (6 } \\
\text { faults) }\end{array}$ & & Small & & Recent. \\
\hline North side Nateekin Bay & & Small & & Recent. \\
\hline $\begin{array}{l}\text { South side Nateekin Bay (may be } \\
\text { continuous with fault on north side } \\
\text { of bay) }\end{array}$ & \multirow{3}{*}{$\begin{array}{l}\text { WNW. } \\
\text { NW. } \\
\text { NW. } \\
\text { E. }\end{array}$} & & \multirow{3}{*}{$\begin{array}{l}\text { S. } \\
\text { S. } \\
\text { NE. } \\
\text { N. }\end{array}$} & \\
\hline $\begin{array}{l}\text { South of Summer Bay } \\
\text { East of Pyramid Peak }\end{array}$ & & Small & & Recent. \\
\hline $11 \frac{2}{2}$ miles east of KOF Point ( 5 faults) & & $20-30$ & & Recent. \\
\hline Headland west of Udagak Stra & $\mathrm{N}$. & - . - & $\mathrm{E}$. & \\
\hline $\begin{array}{l}\text { Northeast of Staraya Bay } \\
\text { Hive Bay }\end{array}$ & E. & 1500 & S. & \\
\hline Bay north of Staraya Bay & NW. & 1,500 & & \\
\hline
\end{tabular}

\section{VOLCANIC STRUCTURES}

The caldera at Makushin Volcano and the craters at the summit of Pakushin Cone are rimmed by faults. The caldera on Makushin Volcano is about $11 / 2$ miles in diameter, and the peripheral fault is buried by the glacier cap. There are two Pakushin craters-a small one eccentrically within an older-and a recent cone within the smaller crater. The persistently gentle dips in the Makushin Volcano area, the thin flows, and the relatively large proportion of flows to pyroclastics present a shieldlike form on which the younger, and in part still active, pyroclastic and composite cones are set.' The Point Kadin explosion pits are along an eastward-trending fissure that was probably formed above molten lava at shallow depth. Similar features have been reported from the top of Kanaga Volcano (Fraser and Barnett, 1959 , p. 234), and Segula Volcano (Nelson, 1959, p. 265).

\section{IINEAR FEATURES}

Aerial photographs of Unalaska Island show linear features that commonly make regular patterns. Many are marked on the ground by slight depressions, knobs, alined drainage, or swamps; glacial erosion emphasizes many of these depressions. Others are marked only by changes in vegetation. A few correspond with known faults, as at Cape Aiak. Most linear features in the Shaler batholith cor- 
respond to joints and the sheared margin of the batholith and are generally shorter than those in the Unalaska formation. Presumably the large remainder represent unexposed joints and faults. Most are undeflected by topography and hence define essentially vertical planes; but a few on Sedanka Island and elsewhere are deflected by topography and thus indicate less steeply inclined planes.

A statistical count of more than 5,000 linear features in the Unalaska formation and the plutonic rocks is shown on the rose diagrams of plate 77, together with a representative selection of features on the map. The variable density of the counted linear features is due partly to the varying quality of aerial photographs. The northern bulge of the island has particularly poor photographic coverage and, hence, few mapped linear features.

The 10 areas for which rose diagrams are given were chosen to determine whether the linear pattern within the Shaler batholith is distinctive from patterns of adjacent areas and whether there is any islandwide change in trend. The linear patterns are independent of the contacts of the Shaler pluton, and many cross the contacts. The rectilinear pattern of Konets Head is strikingly different from the persistent but more disperse northwest-trending patterns found in most of the island, and it is probably significant that the Konets Head pattern is developed on the least altered terrane (compare fig. 89, pl. 77).

The pattern of Konets Head might have been formed tectonically before the batholiths were intruded and the country rock altered, and this rectilinear pattern is now concealed elsewhere on the island by that pattern impressed on both plutonic and wall rocks during a late stage of intrusion. On the other hand, most of the linear features might have been formed after solidification of the batholiths, by orogenic forces perhaps extending the length of the Aleutian arc, and the difference in linear patterns is due either to the different physical characteristics (state of alteration or recrystallization) of the rocks involved, or both the alteration and linear patterns were controlled by the same mechanism. The linear features, in any case, were largely formed after the intrusion of the batholiths, but before the eruptions of Makushin Volcano.

\section{ECONOMIC GEOLOGY}

Parts of Unalaska Island have been prospected for sulfur, gold, and zinc, and there are some deposits of pyrite and chalcopyrite, but almost no production or development work. Mineralized areas are located on figure 89. 


\section{SULFUR}

Sulfur occurs at fumaroles near the vent of Makushin Volcano, where the heat of escaping gases keeps part of the caldera free of ice. Most of the exposed pyroclastics at the solfatara are impregnated with sulfur sublimates. Maddren $(1919$, p. 292) found five samples, taken at depths down to 16 feet, to have an average sulfur content of 23 percent by weight. He measured (p. 288) fumes as hot as $310^{\circ} \mathbf{F}$. 'The account by Maddren (p. 283-292) is the most complete yet made of the geology and estimate of reserves of the sulfur deposits. Lesser accounts were presented by Rothwell (1899, p. 643), Pratt, W. A. (written communication, '1901), Sweeny and Myers (unpublished undergraduate thesis at Massachusetts Inst. Technology, 1908), and Smith $(1936$, p. 83). The glacier-covered volcano summit is accessible only with difficulty, and the prevailing weather is adverse.

\section{GOLD}

The island contains a few poorly auriferous quartz veins (Jaggar, 1908, p. 9 ; and A. J. Collier, 1905, p. 102-103, who is quoted by W. W. Atwood, 1909, p. 151-152; 1911, p. 127-128). Notable among these are those on the northwest slope of Pyramid Peak, 11/2 miles south of Unalaska village, where gold prospectors, probably delayed enroute to or from Nome about 1900, opened a small drift and erected a 3stamp mill; the deposit was soon abandoned.

Another auriferous quartz vein on Amaknak Island, between Dutch Harbor and Unalaska village, was mentioned by Eakle (written communication, 1907?) ; more veins were reported to him by the villagers but none was verified. Two tributaries on the north side of Makushin River near the head of the broad, flat valley that were panned gave, according to Eakle, a few minute grains of gold. Above these two streams is a conspicuous gossan formed of severely altered and pyritized rocks of the Unalaska formation near a contact with granodiorite.

\section{ZINC}

A zinc deposit on Sedanka Island is about $1 / 2$ mile from the southeast cove of Udamat Bay and about $2 \frac{1}{2}$ miles south of the abandoned village of Biorka. Sphalerite is the prominent ore mineral; pyrite is abundant, and some chalcopyrite and galena occur; the gangue is quartz and ankerite. During the month of exploration of this deposit, Webber, Moss, and Rutledge (1946) stripped the overburden adjacent to Lode Creek, mapped the area, and took abundant samples, which were assayed and given preliminary beneficiation studies. The potential ore is readily concentrated by selective flotation. The zinc ore contains minor quantities of copper, lead, silver, and gold. The 
average zinc content of 29 samples taken along a narrow mineralized zone 240 feet long is reported as 6.8 percent; of these, 19 consecutive samples averaged 9.1 percent zinc.

The mineralization is described by Webber, Moss, and Rutledge $(1946$, p. 4$)$ as "confined to the hanging-wall section of a fault striking N. $83^{\circ}$ E. across Sedanka Island and dipping approximately $55^{\circ}$ south $* * *$ Mineral deposition has been controlled structually by a series of nearly vertical fractures $\left(80^{\circ}-90^{\circ} \mathrm{SW}\right.$.) in the diorite forming the hanging wall of the fault. The fractures have an average strike of S. $60^{\circ}$ E. and are more closely spaced and mineralized as they approach the fault plane $* * *$ The footwall is an unmineralized finegrained greenstone." The diorite of the hanging wall of the fault is a basic variety of the plutonic rocks, and the greenstone is part of the Unalaska formation.

Kullerud (1.953, p. 130) has deduced from considerations of the $\mathrm{FeS}-\mathrm{ZnS}$ equilibrium relations that the Sedanka ores were deposited at a temperature below $138^{\circ} \mathrm{C}$.

\section{OTHER MINERALIZATION}

Disseminated pyrite and, less commonly, chalcopyrite occur in many scattered localities on the island. Some of these mineralized acreas, as those on Devilfish Point and on the north side of Broad Bay, are associated with andesite dikes. Other mineralized areas, as those near the head of the Broad Bay Valley, the walls of Anderson Bay, Cape Starichkof, and Broad Bay suggest that much of this enrichment is associated with the granodiorite batholith.

\section{POTENTIALITIES OF ECONOMIC DEPOSITS}

The economic possibilities of mineral deposits on Unalaska Island were not evaluated during this reconnaissance. No economic deposits have yet been found in the Aleutian Islands, which may in part reflect the inaccessibility of the area. Some islands south of the Alaskan Peninsula, notably Unga and Kodiak'Islands, contain small economic gold deposits, and one of the Komandorskiye Ostrova, the westernmost, Russian-owned Aleutian Island group, contained, in beach gravels, native copper that was utilized in the 18th century (Coxe, 1787, p. 206).

On the basis of such comparisons it seems possible that the Aleutian Islands may contain a few small deposits of copper, zinc, or gold; Unalaska Island is probably one of the more favorable islands for such mineralization because of the abundance of intrusive granodiorites. Prospecting the border and roof areas of the granodiorite may prove fruitful. The possibility for producing nonmetallic materials, other than sulfur, from Unalaska Island appears remote. 


\section{SUBMARINE GEOLOGY}

Only a small part of the crest of the Aleutian Ridge is exposed on Unalaska Island, although the island covers half its width. Submarine contours are shown in plate 75 , providing the basis for additional geological observations and inferences. The contoured area covers about 12,000 square miles.

In the reports on several other Aleutian Islands, the submarine topography and geology adjacent to the islands are also incorporated. The submarine studies of P. A. Smith (1937), H. W. Murray (1945), and Gibson and Nichols (1953) are unaccompanied by subaerial geologic mapping.

The contours were constructed from U.S. Coast and Geodetic Survey smooth sheets (hydrographic surveys) dated 1934 through 1939, on scales ranging from $1: 5,000$ in harbors to $1: 20,000$ along most coasts, to $1: 80,000$ and $1: 160,000$ beyond about 10 miles offshore. Nearshore soundings were located by visual fixes on triangulation stations; offshore soundings, by the radio-acoustic ranging method described by P. A. Smith (1935, p. 10-12). The accuracy of a visual fix is usually one part in 500 to 1,000 , and that of a fix obtained by radioacoustic ranging is about one part in 200 to 500 (Smith, 1935, p. 13). Depths were obtained by echo soundings, which vary in abundance from about 850 soundings per square mile on the 1:5,000 smooth sheets to about 2 soundings per square mile on the $1: 80,000$ and $1: 160,000$ sheets. The limitations of echo sounding and the corrections used are described by Gibson and Nichols (1953, p. 11771178).

Above a depth of about 400 feet, the level of the insular shelf, the submarine topography was first contoured with an interval of 25 feet; intermediate contours have been omitted from plate 75 , but they increase the precision of the remaining contours. To obtain a valley configuration, independent evidence of a deflection in a contour was obtained from many contours. In areas of few soundings, valleys and ridges were contoured in the most generalized way as rounded forms, unless specific evidence gave contrary indications. These procedures of depth contouring apparently differ from those used by Smith (1937) to compile his map covering a portion of the Bering Sea near Unalaska Island; he shows more detail than the present map, although the same smooth sheets were used. Depth contours are calculated from mean lower low water, and subaerial contours from mean high water, a difference of about 3 feet (U.S. Coast and Geodetic Survey, 1947, p. 383). 


\section{PHYSIOGRAPHY}

\section{INSULAR SHELF}

The submarine landforms of the insular shelf, the prominent platform capping the Aleutian Ridge, are contoured in greater detail and therefore appear more varied than those of the bordering slopes. The abrupt change of slope at the outer margin of the insular shelf, or shelf break (Dietz and Menard, 1951, p. 1996), is marked approximately by the 400 -foot depth contour, and is sharper north of the island than south of it. The active volcanoes of Unalaska Island and adjacent islands are situated near the northern edge of the shelf; elsewhere the shelf is about 10 to 15 miles wide.

Elongate troughs, as much as 700 feet deeper than the insular shelf, occupy Beaver Inlet, Makushin Bay, Usof Bay, and other fiords. The sides of the troughs near the heads of the fiords are continuous with the valley walls above sea level, but near the open sea the valley walls and trough walls are separated by a bench submerged 200 to 300 feet and continuous with the insular shelf at the mouth of the fiord. In the deepest parts of the troughs, as shown by Beaver Inlet and Makushin Bay, the bottom surfaces are relatively flat and abut into the adjacent walls. Gentle transverse ridges or lips divide the trough bottoms into smaller basins.

Closed basins located off the mouths of most fiords differ from fiord troughs in that they are elliptical in plan and have more gently sloping walls. Few are more than 100 feet deeper than the adjacent insular shelf. On the seaward side of most of these basins are arcuate rims, concave landward, and south of Usof Bay and Akutan Island there are incomplete arcuate rims at depths as great as 600 feet beyond the better defined inner rims. Knobby topography is found inshore from the arcuate rims; in some places mounds and depressions are elongate parallel to the fiords, in others they are irregular or circular.

In Umnak, Unalga, and Akutan Passes submarine topographic features parallel the trend of the passes. The most prominent scarp in Umnak Pass lies 4 miles north of Boulder Bay, faces northwest, and is about 200 feet high. Unalga Pass contains many small ridges, depressions, and small scarps.

The topography of the remainder of the insular shelf is comparatively featureless. Near shore the bottom drops about 100 feet in the first mile and gradually flattens to about 20 feet per mile. Near headlands the submarine topography is irregular; between headlands it is relatively smooth. 


\section{LOWER INSULAR SHFLF}

The lower insular shelf, between the insular shelf and the south insular slope, forms a plane sloping seaward 100 feet per mile, and lies parallel to, and from 7 to 15 miles south of, Unalaska Island. Its average width is 6 miles, but it is nearly absent opposite the ends of the island. Most of the upper margin of the slope coincides with the 400-foot depth contour; however, near the incomplete arcuate rims off Usof Bay and south of Akutan Island the top of the lower insular shelf is at 600 feet. The lower margin of the lower insular shelf is irregular in plan and depth, for the submarine canyons on the south insular slope head at various depths and distances from the island; maximum depth to the edge of the shelf is 2,400 feet.

\section{SOUTH INSULAR SLOPE}

South of the insular shelf and lower insular shelf the insular slope drops about 1,000 feet per mile to the Aleutian bench (Murray, 1945, p. 775) and beyond that into the Aleutian Trench, which is deeper than 21,000 feet in this area. Only the upper part of this slope is shown on plate 75; it is broken by numerous submarine canyons, of which some are oblique, rather than parallel, to the general bottom slope.

\section{NORTH INSULAR SLOPE}

The north insular slope descends from a depth at the shelf break of about 400 feet to the Bering Basin, which is over 7,000 feet deep in the western part of the area. Near the shelf break the slope drops 1,000 feet per mile, but the gradient is gentler at depth. Submarine canyons make the north insular slope irregular in detail. In the steep upper part of the slope, canyons are numerous and intricate. A few of the canyons appear to be flat floored, and some near the top of the north insular slope have a V-shaped cross profile. Most canyon bottoms are shown as rounded because the data are too scanty to define their shapes.

A prominent ridge trends westward from Point Kadin on the north shore of Unalaska Island to Bogoslof Island, just west of the margin of the map.

\section{BERING BASIN AND CONTINENTAL SLOPE}

Little information is obtained from the portion of the broad-floored Bering Basin and Continental Slope in the map area, for the soundings are few. The Bering Basin is wedge shaped in plan, and its floor slopes gently southwestward from its apex, 1,800 feet deep north of Unalaska Bay, to a depth of 7,000 feet.

North of the Bering Basin the Continental Slope rises to about 2,400 feet. A conspicuous canyon more than 15 miles long, the mouth 
of which lies due north of Point Kadin at the edge of the map, trends southeast across this slope and forms a large reentrant in the edge of the continental platform.

\section{WAVE AND CURRENT ACTIVITY}

The dominant geomorphic agent now active on the shallow parts of the insular shelf is wave action, which is impressively effective along the shore. Hanging cirques, hanging stream courses, cliffed headlands, foreshore rock benches, spits, and bars are very common. The broad and almost featureless insular shelf north and south of Chernofski Harbor is best explained by wave erosion and deposition. The simplicity of these slopes is broken only near headlands, and the irregular submarine contours probably show submerged extensions of the headlands. Depth of wave action may be as much as 250 to 350 feet, the depth of the flattest portion of the insular shelf, and the depth above which glacial features are absent. Kuenen $(1950$, p. 228) presents evidence supporting transportation of debris by wave turbulence at this depth; it is likely, however, that the bulk of erosion by waves is restricted to shallower depths.

Along the southern shore of Makushin Bay a submerged bench separates the relatively steep fiord wall below it from an even steeper wall above the sea. This bench is widest, about 3,300 feet, at the mouth of the bay, narrows toward Tarasof Point, and is absent from there to the head of the bay. There are similar narrow benches near the mouths of Usof Bay, Beaver Inlet, and near Eider Point in Unalaska Bay, but only the one flanking Makushin Bay faces the open sea. These benches are believed to be cut by wave action since the ice vacated the fiord. This is suggested by their gradual narrowing toward the head of the bay and away from the direct attack of strong waves, by their continuity with the insular shelf and by the absence of valley-in-valley topography on the island. Had the cutting of the bench preceded the gouging of the fiord, the glacier would undoubtedly have rounded the edges of the bench.

Clear evidence of marine deposition on the insular shelf around Unalaska Island is scarce, but it is widely suggested. The seaward end of the trough in Makushin Bay is flanked by low ridges, the seaward ends of which are slightly recurved away from the intervening trough, as shown by the 200 -foot depth contour north of the trough and by the 300-foot contour south of it. They have the plan of spits and are located precisely where strong currents leaving the trough might be expected to "spill over" its edge, lose their energy on the open shelf, and deposit their load. These recurved ridges are probably submarine spits. Another suggestion of marine deposition occurs in the flat bottoms of some of the troughs. The glacial origin 
of these troughs is discussed below, but the areas of flat bottoms are believed to be underlain by marine sediments. The deep closed troughs should trap much sediment from the adjacent land. Probably much of the outer part of the shelf has a thick veneer of sediments derived from the retreating shore, but there is no direct evidence to support this idea.

\section{GLACIAL FEATURES}

Submarine glaciated landforms include fiords, elongate knobs and depressions, and possibly the basins on the insular shelf. The first two of these features have subaerial counterparts and, in places, are continuous with them.

Submarine glacial deposits include moraines, which form relatively narrow arcs, and possible till, which forms a broad zone of nonelongate knobs and depressions. The arcuate ridge at the junction of Skan Bay and Makushin Bay troughs, which is over 50 feet high, and the arcuate ridge near the mouth of Usof Bay are interpreted as moraines. The arcuate ridges near the shelf break off Makushin and Unalaska Bays and Beaver Inlet are probably also glacial depositional features, and the other irregular ridges on the shelf off the eastern two-thirds and mountainous portion of the island are possible glacial deposits. A line connecting the more conspicuous arcuate ridges is roughly parallel to, and inside of, a line connecting the less conspicuous ridges. These probably represent two glacial episodes; the moraines off Skan Bay and the mouth of Usof Bay may represent a third episode, possibly a pause during retreat of the glaciers. The zone of knobby topography without an elongate pattern in Unalaska Bay, which is conspicuous where contoured using a 25-foot contour interval, is constructional; it has not been ice scoured or modified by currents. Such topography could be the expression of - landslides, volcanic eruption (both postglacial), or ground moraine; of these the last seems most reasonable.

The arcuate ridges near the shelf break need not be end moraines or recessional moraines, for the submarine environment permits another variation of moraine with similar topographic features to form. Conceivably, a ridge resembling a moraine could be formed along the line at which shelf ice becomes free floating. Along this line of contact with salt water the ice sheet probably thins relatively abruptly, and the load, which is generally greater near the bottom of a glacier, would be dropped to form a ridge approximately parallel to the floating ice front and hence concave landward (fig. 103). This ridge would not be a true end moraine, for it does not form at the toe of the shelf ice, and a ground moraine sheet would lie on both sides of this pseudo end moraine. With a fluctuation of 


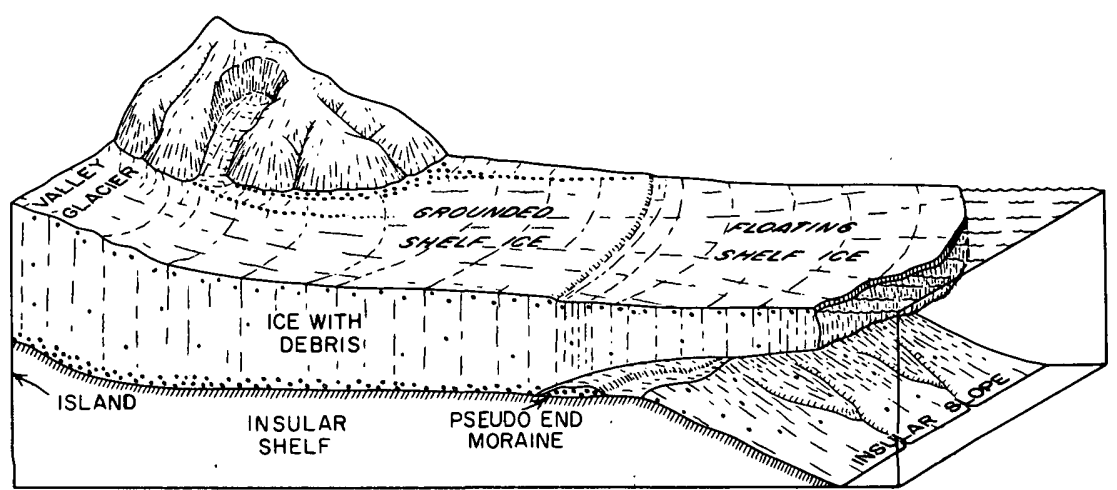

FIGURE 103.-Block diagram showing relations between shelf tce and pseudo end moraine.

sea level or volume of ice the pseudo end moraine would be widely distributed on the flat insular shelf as a true ground moraine. However, where the bottom of the sea drops more steeply from the land, the chance of obtaining a pseudo end moraine is greater, for changes in the sea level or ice thickness will shift relatively little the line along which the ice sheet becomes free floating. Perhaps, then, the arcuate ridges of glaciated deposits along the outer margin of the insular shelf off Makushin Bay and Unalaska Bay were formed at the line along which the ice last rested on the insular shelf for a relatively long time; they may be pseudo end moraines. The relatively smooth upper part of the north insular slope adjacent to the pseudo end moraine may be ground moraine dumped seaward of the pseudo end moraine as shown in figure 103.

In summation, then, probably two and possibly even three episodes of glacial advances or stands are recorded in the submarine physiography. The oldest and most extensive of these, the one least substantiated, passed bevond the outer edge of the insular shelf and onto the lower insular shelf. A second one is recorded by the more distinct basins and their arcuate ridges. During these episodes the higher mountains of Unalaska Island were fringed with shelf ice, but the stand of the sea was probably much lower than it is today. A third episode is marked by terminal or recessional moraines near the mouths of the larger fiords; the mountain glaciers no longer merged on the insular shelf. The cirque-head and terminal moraines near existing glaciers represent the latest advances of the glaciers.

The shoreline was probably free of shelf ice some time after the end of the latest Wisconsin advance and before the climatic optimum, or an estimated 8,000 years ago. The climatic optimum is dated 4,000 to 6,000 years ago by Flint $(1947$, p. 487$)$ and the retreat from the Mankato maximum is dated by Flint (1955, p. 253) at about 
10,800 years, based on carbon-14 determinations. These dates are roughly verified by ionium-method dates from deep sea cores (Hough, 1953, fig. 2), but may be almost doubled by Antevs (1957, table 2); for the present we shall accept the younger age. It is reasonable to suppose that the ice retreat of the last glacial substage was delayed perhaps as much as 1,500 to 2,000 years by the Aleutian climate, so the shoreline of the island was probably ice free between 9,300 and 6,000 years ago-perhaps about 8,000 years ago.

\section{SUBMARINE STRUCTURE}

Geologic structures interpreted from submarine topography include faults and a tilted marine bench. Scarps and alined topography are most pronounced in Umnak and Akutan Passes, where they trend parallel to these passes. Some of these features may be faults, but most are analogous to the linear features described on the island and are structural breaks of unknown origin. The restricted distribution of submarine faults and linear features may indicate that the location of the passes was controlled by structurally weak zones, or that submarine topographic detail is least obscured by marine deposition in passes where currents are strong, or both. From the abundance of linear features on the island the second view is most reasonable.

Submarine valleys that run obliquely down an insular slope appear to be structurally controlled. Several of the large submarine canyons south of Usof Bay fit this criterion, and the canyons immediately north of Cape Idak on Umnak Island may also be structurally controlled, for not only is their trend oblique to the north insular slope, but they also trend parallel to the linear features in Umnak Pass, 7 to 12 miles to the south.

The lower insular shelf may be a marine erosion surface tilted about $1^{\circ}$ southward. This tilting would predate the cutting of the present insular shelf.

The rate of postglacial cutting of the insular shelf at the mouth of Makushin Bay is 3,300 feet in 8,000 years (see p. 664 for determination of time shore has been ice free), or an average of about 0.4 feet a year. The annual erosion of sea cliffs between 21 and 54 feet high at La Jolla, Calif., during 12 years is 0.9 to 1.7 feet (Vaughan, 1932, p. 250 ) and the average rate of retreat of a shore in glacial till in Yorkshire, England, during the last 1,800 years, as well as the present rate, is about 5.5 feet a year (Wheeler, 1902, p. 222). Coleman (1914, p. 437) estimated the annual rate of retreat of cliffs 100 to 350 feet high at Toronto, Canada, as 1.62 feet. These values are calculated for shorelines of differing heights, cut in various materials, and subject to attack of storms of various severity, but they are of the same order of 
magnitude as the estimated annual rate of 0.4 feet on Unalaska Island. Thus far the calculations are within reason.

The width of the insular shelf off the south shore of Makushin Bay is about 12 miles. Assuming, as a first approximation, that marine erosion averaged 0.4 feet per year, this shelf would have been cut during about 160,000 years. But marine erosion should decelerate as it advances, so the rate of erosion used in these calculations is probably substantially smaller than the average rate, and the estimate of 160,000 years needed to cut the shelf is too large. Let us take this age as a conservative one, and pursue the analysis further. During the last 160,000 years the shore was protected by shelf ice during times of maximum glacial advance, and probably was protected intermittently by pack ice. Today the winter pack ice generally reaches the Pribilof Islands and the Bering Sea coast of the western end of the Aleutian Peninsula; twice it was reported to have reached Unalaska Bay (U.S. Coast and Geodetic Survey, 1947, p. 379). During glacial minima the sea level may have been too high to cut much of the shelf; conditions were probably most favorable for this cutting between glacial maxima and minima. Granting the uncertainties, this estimate nevertheless suggests that most of the insular shelf probably was cut during late Pleistocene time.

The relative youthfulness of the insular shelf is also suggested by structural and glacial evidence. The Aleutian arc is an unstable crustal area, and geomorphic surfaces are not apt to be preserved very long under these conditions. The simple form of the valleys and the absence of valley-in-valley topography on Makushin Volcano suggest that only one major cycle of stream and glacial erosion, probably the latest major glaciation, is necessary to explain the present topography. The absence of abrupt changes in depth of the outer edge of shelf in an unstable crustal area also suggests that the shelf is young.

\section{GEOLOGIC HISTORY}

The geologic record of the island began with the deposition of the Unalaska formation in the middle Tertiary; it consists of andesite and basalt and of abundant epiclastic and pyroclastic sediments, deposited partly in an offshore trough or troughs, and partly nearshore. Offshore deposits are represented by argillites, pillow lavas, sills, and tuffs of the south shore and west end of the island; the abundance and thickness of well-bedded argillite indicates deposition undisturbed by waves and currents. Deposition was perhaps in a linear depression, for lava and shallow intrusives are abundant throughout but are nowhere distributed in the manner of a central volcano. The emission of andesite and basalt lavas into muds derived from similar lavas produced many unusual local structures 
ranging from those wholly extrusive to those fully intrusive: flows, pillows, bulbous masses, and sills. Albitization of many of these rocks may have occurred soon after deposition, but at least some of the albitization is a feature of later alteration.

Nearshore deposits are represented by the abundant, coarse, angular clastic rocks common to the Unalaska formation on the northern and eastern parts of the island. There the conglomerates and sedimentary breccias, many with a tuffaceous matrix, form thick, poorly bedded deposits, of which some local lenses or wedges may be submarine talus deposits. Submarine flows are less common than in the offshore deposits. The fossils Cornwallius and Mya cf. M. truncata also indicate a shallow-water environment, and $M y a$ indicates a coldwater environment.

Two or three batholiths and numerous smaller bodies of granodiorite intruded the Unalaska formation at some time between early Miocene and late Pleistocene. As postbatholith history is complex, perhaps the batholithic emplacement was early in this interval, perhaps in late Miocene time. The original batholithic magma may have been formed by local melting of the earth's crust, and emplacement of the batholiths probably took place by a combination of reactive assimilation and melting of roof rocks, stoping, and forceful intrusion. Evidence of assimilation is best preserved near the very irregular roof areas, and the roofs owe their great irregularity to random fluxing or stoping rather than to infolding of country rocks. Some of the argillites are very mafic, and these contributed abundant material to the magma; the effects of the other rocks of the Unalaska formation, felsic to mafic volcanic rocks and minor siliceous argillites, are less noticeable. Assimilation produced widely varied mafic plutonic rocks as gradationally bounded variants along and near wallrock contacts. Contact metamorphism by the granodiorites produced narrow zones of pyroxene, hornblende, and biotite hornfelses, which locally were made schistose by upward magma movements. The amount and intensity of alteration of the Unalaska formation decrease away from the batholiths, which were probably the energy source for most of that alteration.

Late hydrothermal solutions and the relative absence of contaminants combined to leave the core of the Shaler pluton uniformly richer in quartz, potassic feldspar, allanite, and amphibole with respect to pyroxene. Late hydrothermal fliuids replaced small amounts of border rocks and filled small and large joints. Warping, faulting, uplift, and erosion of the rocks of the region followed, and probably in part accompanied, the intrusion of the batholiths. The batholiths with their carapaces of altered country rocks became central structures in the emerging island framework. 
A time of deep erosion of rocks of the Unalaska formation and of the batholiths is recorded by the unconformity at the base of the Makushin volcanics. The unconformity is possibly Pliocene, although it could be as old as Miocene or as young as Pleistocene. The configuration of the unconformity beneath the Makushin volcanics resembles the present-day erosion surface in relief and position of large valleys and ridges. The island, then, was a moderately rugged landmass during Pliocene(?) time, and the gross drainage features have been inherited from that time. Perhaps the lower insular shelf south of Unalaska Island records an early period of marine erosion, or else it is the submarine surface equivalent to the major unconformity. If the age of the insular shelf is accepted as late Pleistocene, then the lower insular shelf, truncated by the upper insular shelf, is early Pleistocene or earlier.

On the northern part of the island, the extrusion of basalt and andesite of the Makushin volcanics perhaps began in late Tertiary or early Pleistocene time, but the bulk of the lavas and pyroclastics of the Makushin Volcano, across which but little insular shelf is cut, are late Pleistocene. Before the close of the Pleistocene, volcanism ceased or diminished considerably, and the volcano was deeply eroded by streams and glaciers. The summit of Makushin Volcano collapsed to form a caldera.

During the two older glaciations most of the high country south of Makushin Bay and around Makushin Volcano was capped by ice which debouched into the sea through fiords and shelf ice. Smaller glaciers and ice fields capped lower parts of the island. The extensive ice sheets and winter pack ice retarded or stopped marine erosion. The last glaciation, during which glaciers reached the sea, was much more restricted than the preceding ones.

Before the last major glaciation, eruption of the Eider Point basalt as flows and pyroclastics began from several vents, including the postcaldera vent at Makushin Volcano. Some of the vents continued active until after the last major glaciations; probably the last of these eruptions produced the lava near Point Kadin.

Sporadic late eruptions from these vents and possibly from volcanoes on adjacent islands added much ash and lapillae to the mantle. Most of the ash eruptions occurred before the arrival of the pre-Aleut people (about 4,000 years ago), but since the glaciation in Skan Bay (about 9,000 years ago). Minor eruptions from the young cone in the caldera of Makushin Volcano, and the emission of gases at fumaroles and of hot water at some springs are the only signs of volcanic activity during historic times. The toes of the residual glaciers probably fluctuated twice within the last few centuries. 


\section{LITERATURE CITED}

Antevs, Ernst, 1957, Geological tests of the varve and radiocarbon chronologies: Jour. Geology, จ. 65, no. ₹. p. 129-148.

Atwood, W. W., 1909, Mineral resources of southwestern Alaska: U.S. Geol. Survey Bull. 379, p. 108-152.

1911, Geology and mineral resources of parts of the Alaska Peninsula : U.S. Geol. Survey Bull. 467, 137 p.

Bramlette, M. N., 1946, The Monterey formation of California and the origin of its siliceous rocks: U.S. Geol. Survey Prof. Paper 212, 57 p.

Byers, F. M., Jr., and others, 1947, Volcano investigations on Umnak Island, 1946, in Alaskan Volcano Investigations Relort 2, pt. 3, 105 p.: U.S. Geol. Survey special pub. (limited disirib.).

Cady, W. M., and others, 1955, The central Kuskokwim region, Alaska: U.S. Geol. Survey Prof. Paper 268, 132 p.

Capps, S. R., 1934, Notes on the geology of the Alaska Peninsula and Aleutian Islands: U.S. Geol. Survey Bull. 857-D, p. 141-153.

Clark, B. L., and Arnold, Ralph, 1923, Fauna of the Sooke formation, Vancouver Island: California Univ. Dept Geol. Sci. Bull., v. 14, no. 5, p. 123-234.

Clarke, F. W., and Hillebrand, W. F., 1897, Analyses of rocks, with a chapter on analytical methods, laboratory of the U.S. Geological Survey, 1880 to 1896 : U.S. Geol. Survey Bull. 148, 306 p.

Coats, R. R., 1950, Volcanic activity in the Aleutian arc: U.S. Geol. Survey Bull. 974-B, p. 35-49

1951, Geology of Buldir Island, Aleutian Islands, Alaska: U.S. Geol. Survey Bull. 989-A, p. 1-26.

1956, Reconnaissance geology of some western Aleutian Islands, Alaska : U.S. Geol. Survey Bull. 1028-E, p. 83-100.

Coleman, A. P., 1914, An estimate of postglacial and interglacial time in North America: Internat. Geol. Cong., 12th, Toronto 1913, Comptes rendus, p. $387-398$.

Collier, A. J., 1905, Auriferous quartz veins on Unalaska Island, in Report on progress of investigations of mineral resources of Alaska in 1904 : U.S. Geol. Survey Bull. 259, p. 102-103.

Collins, H. B., Jr., Clark, A. H., and Walker, E. H., 1945, The Aleutian Islandstheir people and natural history : Smithsonian Inst. War Background 'Studies no. $21,131 \mathrm{p}$.

Coxe, William, 1787, Account of the Russian discoveries between Asia and America : London, Nichols.

Dietz, R. S., and Menard, H. W., Jr., 1951, Origin of abrupt change in slope at continental shelf margin: Am. Assoc. Petroleum Geologists Bull. 35, no. 9, p. 1994-2016.

Durham, J. W., 1950, The 1940 E. W. Scripps cruise to the Gulf of California ; Part 2, Megascopic paleontology and marine stratigraphy : Geol. Soc. America Mem. 43, $216 \mathrm{p}$.

Dutro, J. T., Jr., and Payne, T. G., 1957, Geologic map of Alaska: U.S. Geol. Survey, $1: 2,500,000$.

Flint, R. F., 1947, Glacial geology and the Pleistocene epcch: New York, John Wiley and Sons, $589 \mathrm{p}$.

- 1955, Rates of advance and retreat of the margin of the Late-Wisconsin ice sheet [U.S.] : Am. Jour. Sci., v. 253, no. 5, p. 249-255. 
Fraser, G. D., and Barnett, H. F., Jr., 1959, Geology of the Delarof and westernmost Andreanof Islands, Aleutian Islands, Alaska : U.S. Geol. Survey Bull. 1028-I, p. 211-248.

Fraser, G. D., and Snyder, G. L., 1959, Geology of southern Adak and Kagalaska, Aleutian Islands, Alaska: U.S. Geol. Survey Bull. 1028-MI, p. 371-408.

Freiday, Dean, 1945, The Aleutians, island necklace of the North : Nat. History, v. 44 , no. 10 , p. $444-445$.

Gibson, W. M., and Nichols, Haven, 1953, Configuration of the Aleutian Ridge, Rat Islands-Semisopochnoi I. to west of Buldir I.: Geol. Soc. America Bull., v. 64, no. 10, p. 1173-1187.

Goldschmidt, V. M., 1954, Geochemistry : Oxford, Clarendon Press, 730 p.

Grewingk, Constantin, 1850, Beitrag zur Kenntniss der orographischen und geognostischen Beschaffenheit der nordwest-Küste Amerikas mit den anliegenden Inseln: St. Petersburg (repr. from Mineralog. Gesell. St. Petersburg Verh. 1848-49), $351 \mathrm{p}$.

Hamilton, W. B., 1956a, Variations in plutons of granitic rocks of the Huntington Lake area of the Sierra Nevada, California: Geol. Soc. America Bull., v. 67 , no. 12 , pt. 1 , p. $1585-1598$.

-1956b, Late Mesozoic granitic rocks of central California [abs.] : Geol. Soc. America Bull., v. 67, no. 12, pt. 2, p. 1795.

Hough, J. L., 1953, Pleistocene climatic record in a Pacific Ocean core sample: Jour. Geology, v. 61, no. 3, fig. 2, p. 252-262.

Hrdlička, Aleš, 1945, The Aleutian and Commander Islands and their inhabitants: Philadelphia, Wister Inst. Anatomy and Biology, $630 \mathrm{p}$.

Jaggar, T. A. Jr., 1908, Journal of the Technology expedition to the Aleutian Islands, 1907 : Technology Rev., v. 10, no. 1, p. 1-37.

Jochelson, Waldemar, 1933, History, ethnology, and anthoropology of the Aleut: Washington, Carnegie Inst. Pub. 432, $91 \mathrm{p}$.

Johannsen, Albert, 1950, A descriptive petrography of the igneous rocks: Univ. Chicago Press, v. 1, 318 p.

Kellogg, C. E., and Nygard, I. J., 1951, Exploratory study of the principal soil groups of Alaska: U.S. Dept. of Agriculture, Agriculture Mon. 7, p. 45-46, map.

Kleinpell, R. M., 1938, Miocene stratigraphy of California: Am. Assoc. Petroleum Geologists, $450 \mathrm{p}$.

Kuenen, P. H., 1950, Marine Geology: New York, John Wiley and Sons, 568 p.

Kullerud, Gunnar, 1953, The FeS-ZnS system, a geological thermometer: Særtrykk av Norsk geologisk tidskrift, b. 32, h. 2-4, p. 61-147.

Laughlin, W. S., and Marsh, G. H., 1951, A new view of the history of the Aleutians: Arctic, v. 4, no. 2, p. 75-88.

Lovering, T. S., 1955, Temperatures in and near intrusions, in Pt. 1 of Bateman, A. M., ed., Econ. Geology, 50th anniversary volume: Urbana, Ill., Econ. Geol. Pub. Co., p. 249-281.

Macdonald, G. A., 1939, An intrusive pépérite at San Pedro Hill, California : California Univ. Dept. Geol. Sci. Bull., v. 24, no. 12, p. 329-337.

Maddren, A. G., 1919, Sulphur on Unalaska and Akun Islands and near Stepovak Bay, Alaska : U.S. Geol. Survey Bull. 692, p. 283-298.

McCulloh, T. H., 1954, Mineralogy and petrology, Chap. 7 of Geology of southern California : California Div. Mines Bull. 170, p. 21.

Minato, M., Matsui, M., Ishii, J., 1957, On the stratigraphical position of the Desmostylus-tooth found in Tokachi Province, Hokkaido: Geol. Soc. of Japan Jour., v. 63, no. 740, p. 308-316. 
Murray, H. W., 1945, Profiles of the Aleutian Trench: Geol. Soc. America Bull., v. 56, no. 7, p. 757-781.

Nelson, W. H., 1959, Geology of Segula, Davidof, Khvostof Islands : U.S. Geol. Survey Bull. 1028-K, p. 257-266.

Onodera, S., 1957, A new occurrence of Desmostylus from Ichinoseki City, Iwate Prefecture, with reference to the geology of the locality : Geol. Soc. of Japan Jour., v. 63, no. 739, p. 238-253.

Powers, H. A., Coats, R. R., and Nelson, W. H., 1960, Geology and submarine physiography of Amchitka Island, Alaska: U.S. Geol. Survey Bull. 1028-P, p. 521-554.

Rittmann, Alfred, 1952, Nomenclature of volcanic rocks proposed for use in the catalogue of volcanoes, and key-tables for the determination of volcanic rocks : Bull. volcano l, ser. 2, v. 12, p. 93-100.

Rothwell, R. P., 1899, The mineral industry, its statistics, technology and trade in the U.S. and other countries to the end of 1898-Sulphur and pyrites: New York, Mineral Industry, v. VII, p. 643.

Shapiro, Leonard, and Brannock, W. W., 1956, Rapid analysis of silicate rocks: U.S. Geol. Survey Bull. 1036-C.

Sharp, R. P., 1938, Pleistocene glaciation in the Ruby-East Humboldt Range, northeastern Nevada: Jour. Geomorphology, v. 1, no. 4, p. 296-323.

Simons, F. S., and Mathewson, D. E., 1947, Geology of Great Sitkin Island, in Alaskan Volcano Investigations Report 2, pt. 4, 105 p.: U.S. Geol. Survey special pub. (limited distrib.).

1955, Geology of Great Sitkin Island : U.S. Geol. Survey Bull. 1028-B, 43 p.

Smith, P. A., 1935, The accuracy of soundings and positions obtained by methods used in the United States Coast and Geodetic Survey : Am. Geophys: Union Trans., 16th ann. mtg., General Assembly, App. A, p. 9-14.

1937, The submarine topography of Bogoslof: Geog. Review, v. 27, no. 4, p. $630-636$.

Smith, P. S., 1936, Mineral industry of Alaska in 1934 : U.S. Geol. Survey Bull. 868-A, p. 1-91.

Tröger, W. E., 1952, Tabellen zur optischen Bestimmung der gesteinsbildenden Minerale : Stuttgart, Schweizerbart, p. 147.

U.S. Army Air Forces, Weather Div., 1943, Climatic atlas for Alaska: Washington, Headquarters Army Air Forces, Weather Inf. Br. Rept. 444, 229 p.

U.S. Coast and Geodetic Survey, 1947, U.S. Coast Pilot, Alaska, Part II, 659 p.

Vaughan, T. W., 1932, Rate of sea cliff recession on property of the Scripps Institution of Oceanography at La Jolla, California: Science, new ser. v. 75, p. 250.

Washington, H. S., 1917, Chemical analyses of igneous rocks, published from 1884 to 1913, inclusive, with a critical discussion of the character and use of analyses : U.S. Geol. Survey Prof. Paper 99, 1201 p.

Webber, B. S., Moss, J. M., and Rutledge, F. A., 1946, Exploration of Sedanka zinc district, Sedanka Island, Alaska: U.S. Bur. Mines Rept. Inv. no. 3967.

Wells, A. K., and Bishop, A. C., 1955, An appinitic facies associated with certain granites in Jersey, Channel Islands: Geol. Soc. London Quart. Jour., v. 111, pt. 2, p. 143-166.

Wentworth, C. K., and Macdonald, G. A., 1953, Structures and forms of basaltic rocks in Hawaii : U.S. Geol. Survey Bull. 994, 98 p.

Wheeler, W. H., 1902, The sea coast: London, Longmans. 
$+$

$\because$

2

$+1$

L.

$-$

$r$

-

4

1

r

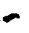




\section{INDEX}

A

Acknowledgments.

Aerlal photographs, cartography from linear features.

Akutan Pass

Albitjzed rocks.

Aleutian Arc.

tslands of.

Aleutlan Ridge.

Aleutian Trench.

Alteration, in plutonic rocks

Alluviation.

Analyzed rocks

andesite porphyry

altered.

ollvine-bearing.

andesite (?) porphyry, albitized......... 602

andesite vitrophyr

basalt porphyry, feldspathic

feldspathic, altered.

$$
\text { ollvine-bearing. }
$$

olivine.

olivine-bearing

dacite (?) porphyry, albitized

dacite vitrophyr pyrite-bearing.

gabbro 602

granite.

$616,620,626$

granodiorite 619,629

615

granogabbro

$616,619,620,627,628,629,630$

quartz gabbro. $627-628$

616,627

quartz monzonite, leuco albite........... 615,630

syenodiorite, recrystallized wallrock.. $619,626-627$

Andesite porphyry, Makushin volcanics...-.- 641

olivine-bearing, Eider Point basalt........

Andesite vitrophyr, Eider Point basalt........

Aplites and pegmatites, petrography.

646

Arcuate ridge, submarine................. 663-664

Argillite, Unalaska formation....... 591-592, 593, 595

Basalt porphyry, olivine ollvine-bearing feldspathic.

Bays

Beaches, physlography

Beaver Inlet, argillite troughs.

Beaver pluton, petrography relation to topography

ench, physiography.

Bering Basin 654

Bishop Point, volcanic mudflow.............. 643

Blueberry Bay, granodiorite.

linear features in rocks................... pl. 77

Border rocks, composition.................... 622 position in pluton........................ 633
Page

594

640

603

dacite vitrophyr........................... 602

\section{C}

Caldera ............. 654

Cape Alak area, dunes......................... 652

gabbro.................................. 626

Igneous stuctures......................... 607-608

Cape Aiak area, mixed rocks .............. 595

Cape Starichkof, quartz gabbro............. 627

Captains Bay, granodiorite.................. 628,630

young flows.............................. 645

Captains pluton, petrography............... $\quad 620$

relation to topography..................... 654

Chernofskd Harbor, pyrite-bearing dacite
vitrophyr............................. 602

Cirques...................................... 646-647

Climate...................................... 580

Colluvium.................................... 649

Conglomerate, Unalaska formation............ 591

Continental Slope............................ 661

\section{D}

Deflation...................................... 650,652

Diabase..................................... 622

Dilation veins, in altered plutonic rocks...... 631

Diorite..................................... 620

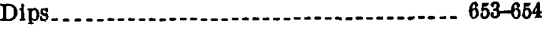

Driftwood Valley, Eider Point basalt......... 644

Dunes....................................... 650,652

Dynamically metamorphosed rock, outcrops. 624

E

Economic geology

Eider, motorship................. 584, 586

Eider Point basalt, analyses................... table 1 analyzed rock, speciflc data............. 645-646

Bishop Point mudflow.................... 643

constructional forms

glaciation.................................. 642,643

Makushin Volcano, andesite vitrophyre.. $\quad 646$

cones, fumaroles, and hot springs..... 642

name and character...................... 641,642

Pakushin Cone, composition of rocks..... 642 olivine-bearing feldspathic basalt..... 646 petrography .......................... 645-646

Point Kadin vents, composition and forms.............................. 643

pyroclastic deposits....................... 642

Sugarloaf Cone and lava flows........... 643-644

ollvine-bearing andesite porphyry.... 646

olivine-bearing feldspathic basalt porphyry........................ 640 


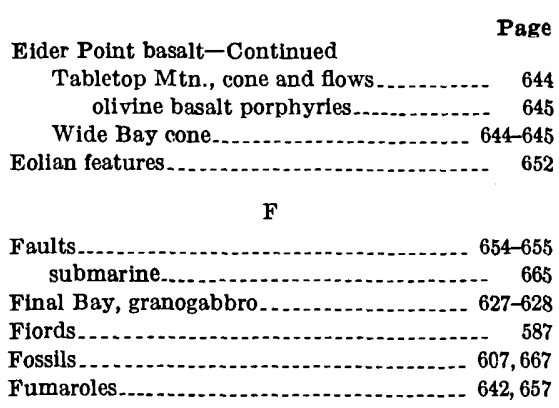

G

Gabbro, Cape Alak

Geography of area

626

587-590

Geologic history .............................. 666-668

Geologic reconnaissance...................... 584-585

Glacial features, submarine................. 663-664

Glacial land forms and deposits.............. 646-648

Glacial outwash and vegatation. .......... 648-649

Glaciation of lava flows........................ 644

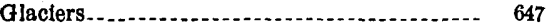

Glacier Valley

Gold..................................... 657

Granite................................... 619,629

leuco........................... 615,619,620

Granodiorite, Captains pluton............... 628

Final Bay................................ 627-628

Shaler pluton ............................ 628

Skan Bay........................ 627,629-630

Grandiorite and related rocks, age........... 612

aplite and pegmatite.................. 610,620

Beaver pluton....................... 610,619-620

Captains pluton.................... 610,612,620

emplacements ........................ 610,612

Field relations......................... 610-612

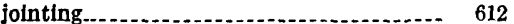

lineation along batholith border....... 610-611

pendants................................. 610,611

recrystallized wallrock . . . . . . $622-624,627$

shaler pluton.......................... $610,614,619$

small intrusive bodies.................. 610,620

topographic forms ............................ 610

Graywacke, Unalaska formation............ 591, 593

$\mathrm{H}$

Hanging valleys

History of area.

Hive Bay.

albitized andesite (?) porphyry $\ldots 602-603$

Holocrystalline rocks, fence diagram of distribution

percent frequency of mineral amounts and plagioclase composition ....... pl. 76

Hot springs..................................... 642 Humpback Bay, altered andesite porphyry. 601,602

\section{I}

Igneous and sedimentary rocks

Intrusive bodies in batholith

$590-646$

Intrusive bodies $620-622$

erosion.
Insular shelf, lower

Page

physiography ......................... 659-660

Insular slopes. . . . . .

Intrusive flows, Unalaska formation ....... 590,595

$\mathrm{K}$

Kalekta Bay, andesite porphyry ............. 602

Kashaga Bay, linear features in rocks.......... pl. 77

Kismaliuk Bay, pillow structure............. 597

Kof Point, granite.......................... 629

Konetz Head, linear features in rocks.......... pl. 77

Koriga Point, constructional forms, Eider Point basalt........................ 643

moraines

L

Linear features................... 655-656, 665; pl. 77

Location and extent of area............. 585, 586-587

Lofty Mountain, lava flows................... 593

Logistic problems . ....................... 584, 586

\section{M}

McLees Lakes, basalt porphyry........... 640, 644 young flows................................ 645

Makushin Bay, argillite................... 591 troughs........................... 660

Makushin Valley, Eider Point basalt.......... 644

Makushin volcanics, analyses of volcanic rocks ....................... table 1 analyzed rocks, specific data........... 641 . basal unconformity ................. 634-638,668 general description of rocks............... 638 glacial outwash ................... 649 name and character.................... 634 petrography of rocks.................. 638-639 Pleistocene age.......................... 641 topographic effect.......................... 638 vents....................................... 638

Makushin Volcano, caldera................ 642,654 Elder Point basalt................. 642, 643, 646 erosion of.................................. 666 fumaroles and hot springs................. 642 geologic relations........................ 634-638 glacial outwash and vegetation........... 648 glaciers near............................ 647 petrography ... . . . . . . . . . 637-641 physlography............................ 587, 634

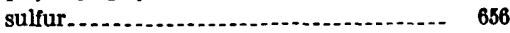
ollvine-bearing andesite porphyry........ 641

Marine bench, tilting...................... 665

Marine deposits.......................... 652-653 basin...... 607 near-shore.............................. 606 Marine erosion . ...................... 652, 665-686 Melagabboric composition, recrystallized sediments.............................. 622 Mineral amounts, percent frequency in holocrystalline rocks................... pl. 76

Mineralization........................ 608-609, 658

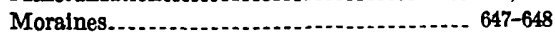

$\mathrm{N}$

Naginak Cove, geographic distribution of holocrystalline rocks.................... pl. 78 665-666 Nateekin Bay area, basalt complex.......... 639 
Nateekin River

Nateekin Valley, young flows.

\section{$\mathbf{P}$}

Pack ice.

Pakushin Cone, craters at Eider Point basalt............... 640-641, 642,646 intrusive dacite and andesite

Petrography of the batholith, accessory minerals

616 analyses of holocrystalline rocks. table 1 analyzed rocks, specific data $624-630$ border rocks, composition............... 622 comparative mineralogy ................... 624

felsic minerals.......................... 612-616 general $612-619$ mafic minerals, description............... 616 distribution......................... 624 plutonic rocks, alteration in . . . . . . . 630-631 roof pendants........................... 619 terminology ............................. 612

textures. . . .

wallrock inclusions in plutonic rocks...... $\quad 622$ wallrocks, descrfption recrystallization................. $620,622-624$

Physiography ............................. 660

Pillow structure, origin ..................... 607-608

Unalaska formation..................... 595

Plagioclase composition, percent frequency in holocrystalline rocks............... pl. 76

Plutonic rocks, assimllation of walirock..... 631-632 ground surface........................... 616 compositional zones...................... 631 magma ............................. 631, 633 mechanism of emplacement.............. 632-633 summary and interpretation........... 631-634 mineralogy of

Plutons, geomorphic control................ 654

Point Kadin, Eider Point basalt.............. 643 submarine geomorphology................ 661

Point Kadin flow, moraine at................ 648

Portage Bay, argillite......................... 591

Postglacial explosive activity.................. $\quad 650$

Pyramid Peak, auriferous quartz............ $\quad 657$

Pyroclastic rocks, Eider Point basalt.......... 642 Unalaska formation....................... 591

\section{Q}

Quartz diorite.

Quartz gabbro, Tarasof Point

Quartz monzonite............................ 619, 620 leuco albite, 3600 Mountain

\section{$\mathbf{R}$}

Raven Bay, granodiorite

Recrystallized wallrocks mixed rock

s

Sea-level change

Sedanka Island, zinc...................... 657-658 Settiement.
Page

Shaishnikof River, linear features in rocks....- pl. 77 Shaler pluton, geographic distribution of holocrystalline rocks................... pl. 78

petrography ............................... 618

relation to topography ................ 654

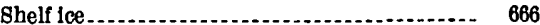

Skan Bay area, geographic distribution of holocrystalline rocks.................... pl. 78 granite ................................ 629 granodiorite. linear features in rocks...................... pl. 77 syenodioritic wallrock. .................... $\quad 627$ Snowflelds and icefields........................ 647 Snowline, Plelstocerie and Recent......... 646, 647 Soll-ash profiles_......................... 650, 651 Staraya Bay, linear features in rocks........... pl. 77 Structural geology........................... 653-656 Submarine canyons, structural control........ 665 Submarine geology . . . . . . . . . . . . 659-666; pl. 75 structure................................... 665-666

Submarine topography, compilation of....... $\quad 584$

Sugarloaf Cone area, andesite porphyry....... 641 Eider Point basalt.................. 643-644, 646 feldspathtc basalt porphyry................ 640

Sulfur.......................................... 657 Summer Bay, feldspathic basalt porphyry.... $\quad 601$ Surficial deposits and geomorphology....... 646-653 Surveyor Bay, dunes........................ 652

$\mathbf{T}$

Tabletop Mountain, cone and flows......... 645 olivine basablt porphyry............... $\quad 640$

Tarasof Point, quartz gabbro

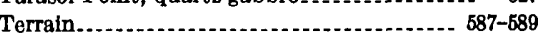

3600 Mountain, granite................... 629 leuco albite quartz monzonite............ 630

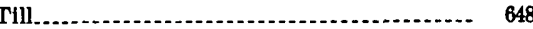

Topography of unconformity beneath Makushin volcanics...................... 638

\section{$\mathrm{U}$}

Udagak Strait, linear features in rocks......... pl. 77 Udamak Cove, linear features in rocks........ pl. 77 Unalaska, linear features in rocks............ pl. 77 Umnak Pass...................... 660, 664

Unalaska Bay, soll profles near............ 650,651

Unalaska formation, alteration...... 603-606, 608-609 analyzed rocks, data. .................... 601-603 andesite, albitized........................ 600-601 basalt and dacite, albitized ............... $\quad 600$ bedding, sedimentary rocks................ 583 bulbous intrusive bodles............. 595, 598, 599 clastic components........................ $\quad 593$ depositional environment.................. $\quad 607$ dikes. . . fauna..................... 606-607 general............................... $\quad 600$ hornfels............................... 606-607 igneous structures description . - 593, 595, 598-599 origin............................... 607-608 intrusive flows............................ 691, 595 intrusive rocks.......................... 595-598 lave flows................................ 593 


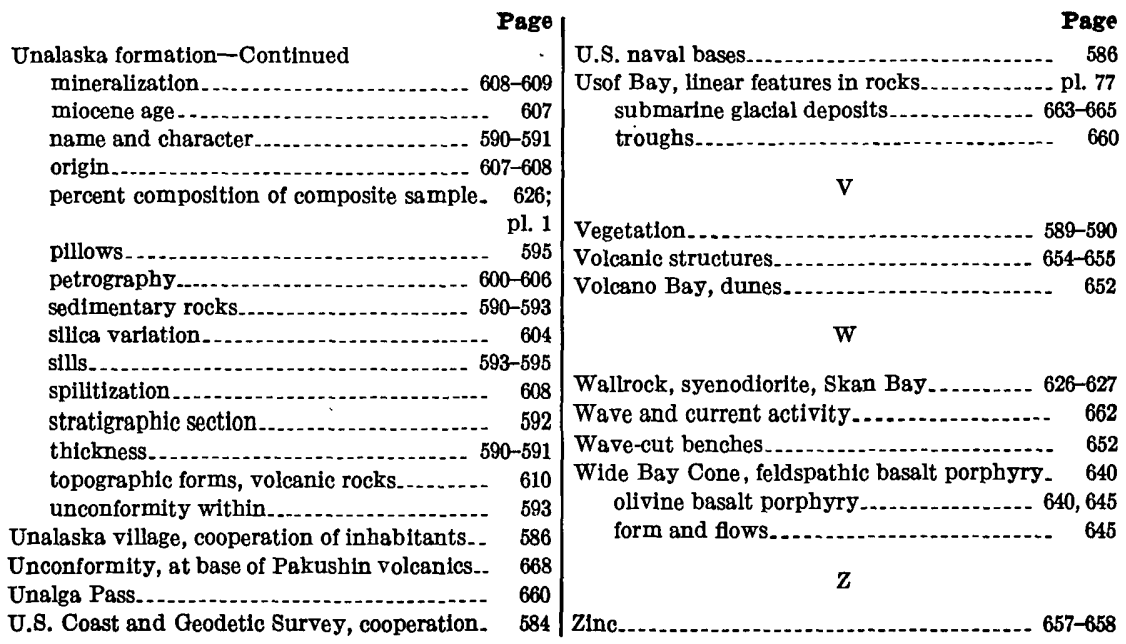

